\title{
Opportunities for Energy Efficiency and Open Automated Demand Response in Wastewater Treatment Facilities in California - Phase I Report
}

\author{
Alex Lekov \\ Lisa Thompson \\ Aimee McKane \\ Katherine Song \\ Mary Ann Piette \\ Lawrence Berkeley National Laboratory
}

One Cyclotron Road

MS 90R4000

Berkeley, CA 94720

April 2009

This work described in this report was coordinated by the Demand Response Research Center and funded by the California Energy Commission, Public Interest Energy Research Program, under Work for Others Contract No. 500-03-026 and by the U.S. Department of Energy under Contract No. DE-AC02$05 \mathrm{CH} 11231$. 



\section{Acknowledgements}

This work described in this report was coordinated by the Demand Response Research Center and funded by the California Energy Commission (CEC), Public Interest Energy Research (PIER) Program, under Work for Others Contract No. 500-03-026 and by the U.S. Department of Energy under Contract No. DE-AC02-05CH11231.

The authors wish to thank Ivin Rhyne, Chris Scruton, and Roger Levy (California Energy Commission).

We would also like to thank the members of our Technical Advisory Committee: John Bidwell (QuEST), Joe Cantwell (SAIC), Austen D’Lima (SDG\&E), Ray Ehrhard (Washington University), James Filanc (Southern Contracting), John Howard (Power \& Process Engineers), Jonathon Loiacono (City of San Francisco), Jayne Ng (PG\&E), Kathleen O'Connor (NYSERDA), Siva Sethuraman (PG\&E), and Cecilia Tai (PG\&E) for their input, suggestions and comments. We appreciate the helpful comments provided by Ivin Rhyne (CEC).

\section{DISCLAIMER}

This document was prepared as an account of work sponsored by the United States Government. While this document is believed to contain correct information, neither the United States Government nor any agency thereof, nor The Regents of the University of California, nor any of their employees, makes any warranty, express or implied, or assumes any legal responsibility for the accuracy, completeness, or usefulness of any information, apparatus, product, or process disclosed, or represents that its use would not infringe privately owned rights. Reference herein to any specific commercial product, process, or service by its trade name, trademark, manufacturer, or otherwise, does not necessarily constitute or imply its endorsement, recommendation, or favoring by the United States Government or any agency thereof, or The Regents of the University of California. The views and opinions of authors expressed herein do not necessarily state or reflect those of the United States Government or any agency thereof or The Regents of the University of California.

\section{DISCLAIMER}

This report was prepared as the result of work sponsored by the California Energy Commission. It does not necessarily represent the views of the Energy Commission, its employees or the State of California. The Energy Commission, the State of California, its employees, contractors and subcontractors make no warrant, express or implied, and assume no legal liability for the information in this report; nor does any party represent that the uses of this information will not infringe upon privately owned rights. This report has not been approved or disapproved by the California Energy Commission nor has the California Energy Commission passed upon the accuracy or adequacy of the information in this report 



\section{TABLE OF CONTENTS}

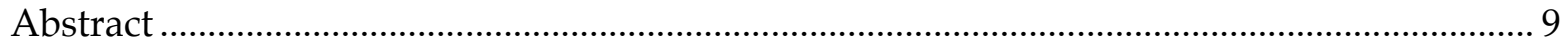

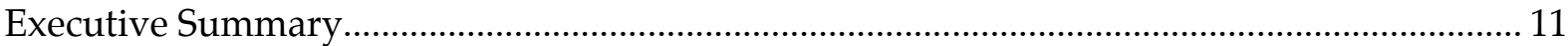

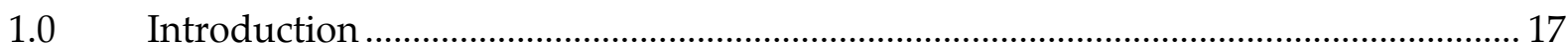

2.0 Characteristics of Wastewater Processing Industries .................................................. 21

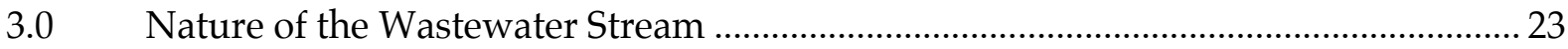

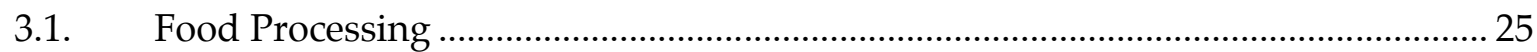

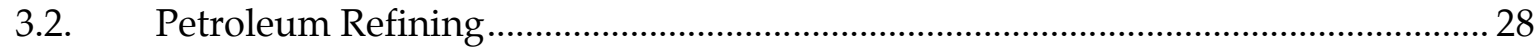

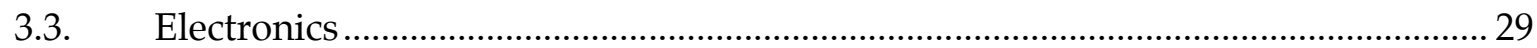

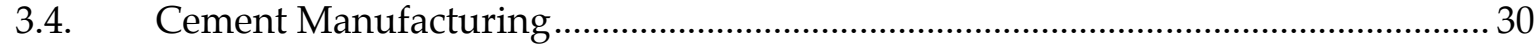

3.5. Municipal Wastewater Treatment Facilities ............................................................ 31

Energy Use in Wastewater Treatment Facilities......................................................... 33

4.1. Factors Impacting Energy Intensity in Wastewater Treatment Facilities............... 33

4.1.1. Energy Use in Food Processing Facilities ............................................................ 35

4.1.2. Energy Use in the Petroleum Refining Industry ............................................... 37

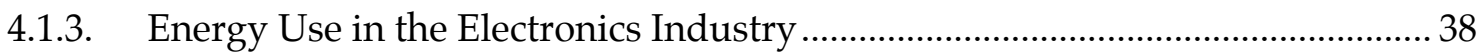

4.1.4. Energy Use in the Cement Manufacturing Industry ............................................ 38

4.1.5. Energy Use in Municipal Wastewater Treatment Facilities ............................... 39

5.0 Wastewater Treatment Processes ................................................................................ 41

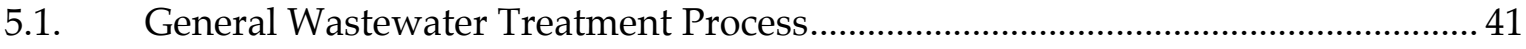

5.2. Municipal Wastewater Treatment Process ............................................................ 41

5.3. Food Processing Wastewater Treatment Process..................................................... 44

5.3.1. Food Processing - Fruit and Vegetable................................................................. 46

5.3.2. Food Processing - Meat and Poultry ..................................................................... 46

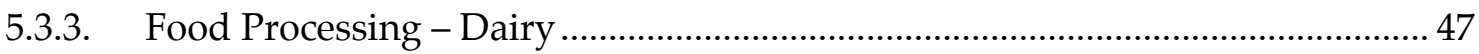

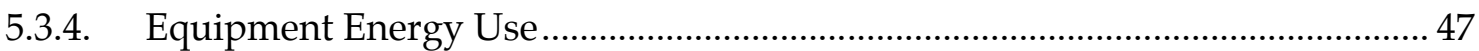

5.4. Emerging Wastewater Treatment Technologies ..................................................... 50

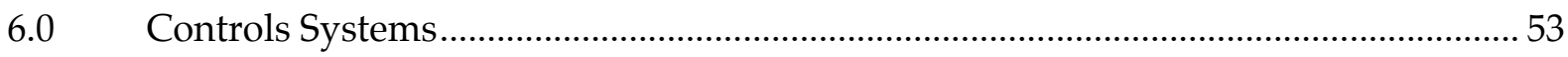

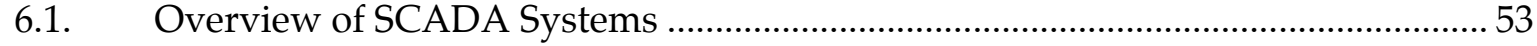

6.1.1. SCADA System Structure................................................................................... 54

6.1.2. Applications of SCADA in Wastewater Treatment Facilities ............................ 55

6.2. Wastewater Treatment Equipment Controls........................................................... 56

7.0 Energy Efficiency and Demand Response Opportunities .......................................... 61

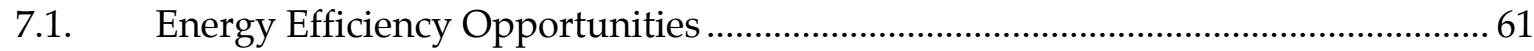

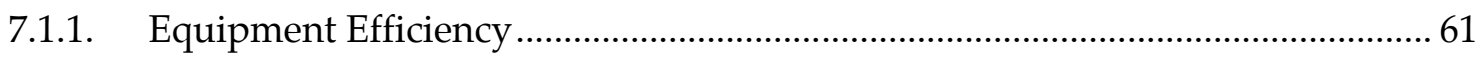

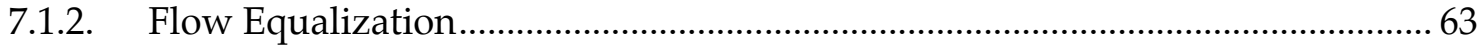

7.1.3. Lighting and Heating, Ventilating, and Air Conditioning ................................. 64

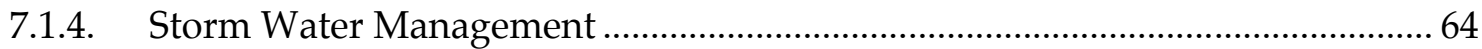

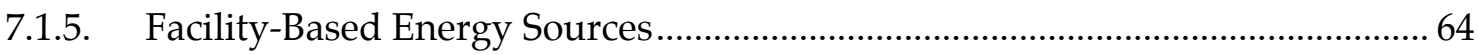




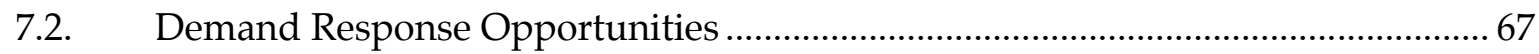

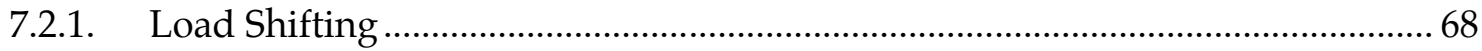

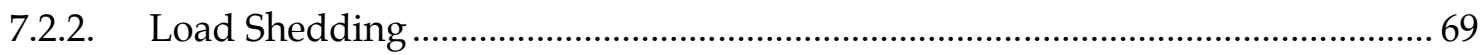

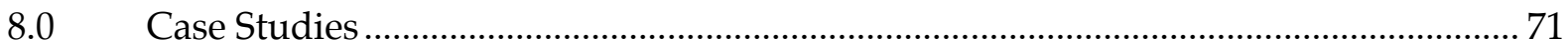

8.1. Southern California Wastewater Treatment Facility ............................................... 71

8.2. Town of Discovery Bay Community Services District............................................. 72

8.3. Encina Wastewater Authority............................................................................. 72

8.4. Moulton Niguel Water District.................................................................... 73

8.5. Dublin San Ramon Services District ……………………………………….... 73

8.6. East Bay Municipal Utility District …………………........................................... 73

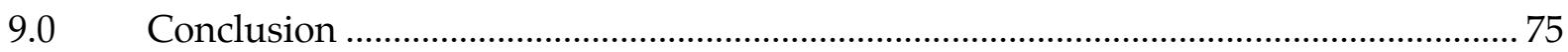

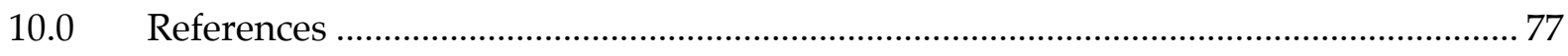

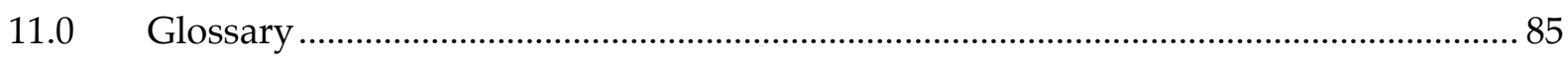

\section{List of Tables}

Table 1. San Francisco Region Effluent Monitoring Requirements Conventional

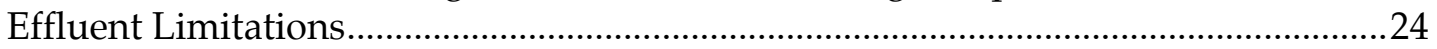

Table 2. Los Angeles Region General Effluent Limitations Discharges of Non-process Wastewater to Surface Waters ..........................................................................................24

Table 3. Wastewater Characterization of Typical Rendering Plant .................................26

Table 4. Federal Effluent Limitation Guidelines for Slaughterhouses* ...........................27

Table 5. Federal Effluent Limitations Guidelines for Canned and Preserved

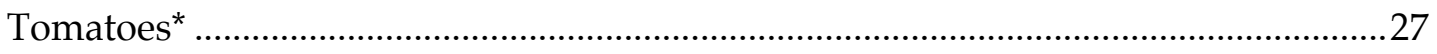

Table 6. Federal Effluent Limitations for Dairy Processing Facilities ${ }^{*}$.............................27

Table 7. Composition of Untreated Petroleum Refinery Wastewater ..............................28

Table 8. Federal Effluent Regulations for Petroleum Refining ${ }^{*}$.........................................2

Table 9. Federal Effluent Regulations for the Semiconductor Industry ..........................30

Table 10. CFR Effluent Limitation Guidelines for Cement Manufacturing..................31

Table 11. Typical Composition of Untreated, Medium Strength Residential Wastewater ....................................................................................................

Table 12. Secondary Treatment Standards for Municipal Wastewater.........................32

Table 13. Energy Intensity of Wastewater Treatment Facilities .....................................34

Table 14. Comparison of Energy Use for Wastewater Treatment..................................35

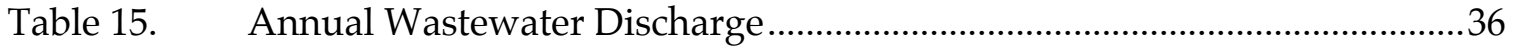


Table 16. Equipment Commonly Used in Wastewater Treatment Facilities...

Table 17. Effluent Hydropower- Kilowatt Output as Function of Head and Flow...66

\section{List Of Figures}

Figure 1. Food Processing Wastewater Treatment Facility - Summer ........................37

Figure 2. $\quad$ Food Processing Wastewater Treatment Facility - Winter ..........................37

Figure 3. Municipal Wastewater Treatment Facility Load Pattern - Summer ...........39

Figure 4. Municipal Wastewater Treatment Facility Load Pattern - Winter .............40

Figure 5. Municipal Wastewater Treatment Process .................................................. 42

Figure 6. Food Processing Wastewater Treatment Process ........................................46

Figure 7. Municipal Wastewater Treatment Equipment Energy Use ......................... 48

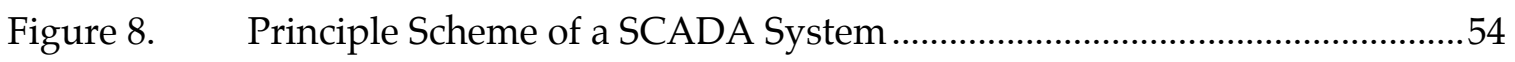

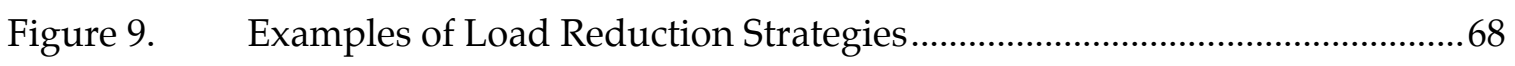

Figure 10. Load Reduction at Site During Normal Facility Operation .........................71 



\begin{abstract}
This report summarizes the Lawrence Berkeley National Laboratory's research to date in characterizing energy efficiency and automated demand response opportunities for wastewater treatment facilities in California. The report describes the characteristics of wastewater treatment facilities, the nature of the wastewater stream, energy use and demand, as well as details of the wastewater treatment process. It also discusses control systems and energy efficiency and automated demand response opportunities. In addition, several energy efficiency and load management case studies are provided for wastewater treatment facilities.

This study shows that wastewater treatment facilities can be excellent candidates for open automated demand response and that facilities which have implemented energy efficiency measures and have centralized control systems are well-suited to shift or shed electrical loads in response to financial incentives, utility bill savings, and / or opportunities to enhance reliability of service. Control technologies installed for energy efficiency and load management purposes can often be adapted for automated demand response at little additional cost. These improved controls may prepare facilities to be more receptive to open automated demand response due to both increased confidence in the opportunities for controlling energy cost/ use and access to the real-time data.
\end{abstract}

Keywords: Open automated demand response, energy efficiency, controls, wastewater treatment facilities, demand response 



\section{Executive Summary}

\section{Overview}

Since 2006, the Industrial Demand Response Team, which is part of the Demand Response Research Center (DRRC) at Lawrence Berkeley National Laboratory (LBNL), began researching and evaluating demand response (DR) opportunities in industrial facilities. First, the research team collected and analyzed data on recommended DR strategies included in utility integrated audits. Second, the team supported several California electric utilities and their contractors to identify potential Open Automated Demand Response (OpenADR) industrial participants and provided technical assistance in evaluating the DR sites. Third, the research team conducted in-depth analyses of industrial sectors that appeared to have ADR potential and analyzed industrial DR technical capacity.

This report builds on ongoing DRRC research, development, demonstration, and deployment activities of the DRRC related to OpenADR. OpenADR is a set of continuous and open communication signals and systems provided over the Internet to allow facilities to automate their demand response with no "human in the loop." OpenADR is intended to standardize DR event information between DR service providers (utility / Independent System Operator) and consumers (facilities / participants and aggregators).

In 2008, municipal and industrial wastewater treatment facilities were selected as a focus of LBNL's OpenADR research for the following reasons:

- Wastewater treatment facilities are energy-intensive facilities and have significant electricity demand during utility peak periods.

- Some wastewater treatment facilities have already implemented energy efficiency measures that can provide a base for participation in OpenADR programs and tariffs.

- Some technologies and control strategies that have enabled successful energy efficiency improvements in municipal wastewater treatment facilities have the potential to be introduced into industrial wastewater treatment facilities as DR strategies.

This report discusses the energy efficiency and demand response potential in wastewater treatment facilities for municipalities and four key California industries (food processing, petroleum refining, electronics, and cement). Wastewater treatment in the industrial sector is often overlooked as an opportunity for energy efficiency and automated demand response in California. Energy efficiency measures that have been successfully implemented in municipal wastewater treatment facilities can serve as best practices that could be applied to form the basis for demand response in industrial wastewater treatment facilities. 
This research studies the potential for implementing OpenADR in the wastewater treatment sector. It includes a characterization of wastewater treatment loads and variation in treatment processes, availability of current technologies and control systems, impact of factors such as federal regulatory measures, perceived uncertainties associated with the control capabilities for implementing OpenADR strategies, and concerns about interrupting the scheduled processes and assuring wastewater effluent quality.

Wastewater treatment facilities have the potential to benefit from the implementation of DR and energy efficiency strategies. However, there is little comprehensive research that summarizes industry-specific data regarding energy use and intensity and how to target wastewater treatment for OpenADR activities. This report seeks to fill this knowledge gap by describing the energy end-uses within wastewater treatment facilities, the technologies used to control energy use, and how equipment and facility controls can be targeted for energy efficiency and OpenADR strategies.

\section{Research Goals}

The goal of the DRRC industrial research is to facilitate deployment of industrial OpenADR that is economically attractive and technologically feasible. Such OpenADR can carry out load reduction strategies using customized pre-programmed OpenADR strategies that can be activated upon receiving a DR event or price signal. It also can maximize load reduction savings while maintaining effluent quality to satisfy regulations. The goal in conducting this research is to provide policy makers, utilities, and facility management with the information necessary to design, retrofit, and operate energy efficient wastewater treatment facilities capable of participating in DR events. Decisions concerning participation in OpenADR and load management require facility operators to acquire knowledge about the magnitude, time, and duration of their energy use. This leads to one of the team's research hypotheses, that facilities participating in energy efficiency programs will be more, not less, likely to initiate OpenADR and load management actions because they will have a more complete understanding of their use. This knowledge can assist a facility in evaluating:

- The potential benefits of energy efficiency and demand response.

- The limitations and risks of demand response depending on facility technologies, energy-use profile, and the characteristics of the wastewater.

- The types of technology installations or retrofits needed for energy efficiency and OpenADR.

- The impact of different strategies for demand response events.

- How specific facility equipment or systems would be controlled during a demand response event. 


\section{Methods}

This report was compiled after extensive research on literature concerning wastewater treatment specifications, demand response strategies, and energy efficiency upgrades. The literature search included 157 sources ranging from peer-reviewed studies describing energy efficiency measures, demand response-related technologies, and equipment controls to case studies of energy efficiency and load management applications. While the literature provides relatively comprehensive information about the basic equipment and controls included in the design of the wastewater treatment facilities, little has been written about the demand response potential of the existing controls and equipment. This study reviews existing resources and describes case studies to demonstrate existing DR applications. In addition, the study gives a preliminary assessment of the state of OpenADR-readiness in wastewater treatment facilities.

\section{Key Findings}

This research indicates that, under the appropriate conditions, wastewater treatment facilities are excellent candidates for OpenADR and that, of the sectors studied, the major opportunities for demand response are most applicable to wastewater treatment facilities in the food processing industry as well as municipalities. In 2008, the first season of active recruitment in the industrial sector, 35 industrial facilities agreed to participate in OpenADR in the Pacific Gas \& Electric (PG\&E) and Southern California Edison territories, but none of them were wastewater treatment facilities. There are hundreds of municipal and food processing wastewater treatment facilities in California. Some of the wastewater treatment facilities in both of these sectors have already implemented energy efficiency and demand limiting measures that, in some cases, provide the technologies and control strategies needed for OpenADR. These proven measures could be further employed as demand response opportunities when needed.

\section{Key Finding: Energy efficiency and load management technologies may enable successful participation in demand response events.}

- Individual equipment controls and centralized control systems that are installed as part of the facility process controls or for energy efficiency and load management purposes may also provide the necessary conditions and allow the degree of control necessary to conduct demand response activities.

- Equipment in the wastewater treatment process can be integrated with centralized control systems to enable greater facility control and decreased energy use and demand. Specific technologies, such as variable frequency drives, allow for capacity adjustment which can be modified to reduce energy demand during demand response events. These components can be connected to integrated supervisory control systems which maintain facility operations while reducing demand. 
Key Finding: Facility control systems are suitable for open automated demand response when they are integrated into centralized control systems.

- Many wastewater treatment facilities have centralized controls which can support OpenADR and the market for these control systems in wastewater treatment facilities is growing at about five percent annually. Existing industrial controls, if DR-enabled, hold significant promise for integration into an OpenADR framework. Knowledge of the facility equipment and system design and operational constraints is a key component of effective OpenADR.

Key Finding: Over-oxygenation of wastewater prior to a demand response event can reduce facility energy demand.

- Over-oxygenating of wastewater by over-aerating wastewater prior to a DR can reduce the energy demand of wastewater treatment facilities during a DR event. While limited field testing has been done, this load shifting strategy appears to show promise for significant demand response reductions. However, facilities must carefully monitor dissolved oxygen levels to assure that the regulation requirements are met.

Key Finding: Utilizing storage capacity can reduce facility peak demand.

- Existing facility storage capacity can be used to store untreated wastewater during a demand response event. This reduces the facility demand by shifting this wastewater processing load to off-peak periods.

Key Finding: Shifting backwash filter pump use can reduce facility peak demand.

- Backwash pumps can be operated during off-peak hours to reduce peak demand in wastewater treatment facilities. Control systems can be used to monitor the filter-status parameters and allow the backwash pumps to be operated when needed, as opposed to a preset schedule, as a daily peak load management strategy. This strategy could be enhanced to shift or delay the backwash process during a demand response event. 


\section{Next Steps and Future Research}

This research has identified opportunities for additional study that would build on the body of knowledge in this report. It represents a mid-point in this research effort and the future work should consider the following:

1. Utilize the results of the Industrial Controls Survey and discussions with control experts to better understand existing controls capability in wastewater treatment facilities.

2. Performing field studies to add to the body of knowledge about OpenADR implementation experience in wastewater treatment facilities.

3. Continue to survey the literature for case studies and technology advances that might affect OpenADR potential.

4. Develop DR Quick Assessment Tool for wastewater treatment facilities building on office and retail tools. This would benefit wastewater treatment facility operators by providing them with the capability to assess facility performance within some range of performance criteria thus enhancing their capabilities to implement OpenADR.

5. Scaling and standardizing the OpenADR for control systems to apply to wastewater treatment facilities to reduce implementation cost, and increase DR reliability and effectiveness.

6. Improve understanding of how facility operations impact the effectiveness of DR strategies and identify the best operation practices and behaviors to enhance the impact of DR activities.

Phase II of the wastewater treatment research will involve utilizing the findings of this report and the recommendations of the expert working group to perform field studies to collect and analyze data, enhancing the understanding of demand response opportunities in wastewater treatment facilities. 



\subsection{Introduction}

\section{Background and Overview}

Demand response (DR) is a set of actions taken to reduce electric loads when contingencies, such as emergencies or congestion, occur that threaten supply-demand balance and/or market conditions occur that raise electric supply costs. DR programs and tariffs are designed to improve the reliability of the electric grid and to lower the use of electricity during peak times to reduce the total system costs (Flex your Power 2008; Pacific Gas and Electric Company 2008). Open Automated Demand Response (OpenADR) is a set of standard, continuous, open communication signals and systems provided over the Internet to allow facilities to automate their demand response with no "human in the loop" (Piette 2009).

Since 2006, the Industrial Demand Response Team, which is part of the Demand Response Research Center (DRRC) at Lawrence Berkeley National Laboratory (LBNL) began researching and evaluating demand response (DR) opportunities in industrial facilities. First, the research team collected and analyzed data on recommended DR strategies included in utility integrated audits. Second, the team supported several California electric utilities and their contractors to identify potential OpenADR industrial participants, and provided technical assistance in evaluating the DR sites. Third, the research team conducted in-depth analyses of industrial sectors that appeared to have ADR potential, and analyzed industrial DR technical capacity.

Implementing industrial OpenADR presents a number of challenges, both practical and perceived. Some of these include: the wide variation in loads and processes, resourcedependent loading patterns that are driven by outside factors such as time-critical processing, the perceived uncertainties associated with the control capabilities for implementing OpenADR strategies, and concerns about interrupting the scheduled processes and assuring product quality regulations.

Wastewater treatment facilities have the potential to benefit from the implementation of demand response and energy efficiency strategies. However, there is little comprehensive research that summarizes industry specific data regarding energy use and intensity, information describing the energy savings potential in wastewater treatment facilities, and how to target wastewater treatment for demand response activities. This report seeks to fill this knowledge gap by describing the energy end uses within wastewater treatment facilities, the technologies used to control energy use, and how equipment and facility controls can be targeted for energy efficiency and demand response strategies. 


\section{Research Scope}

Historically, industrial DR programs have engaged facilities to participate in manual or semi-automated demand response largely in response to reliability issues. The Industrial DR Team began conducting research on strategies for engaging California industry in OpenADR, with a particular focus on the practical potential of 1) small, frequent load sheds or shifts that could be accommodated without any significant disruption in facility operations and 2) the decision-making strategies that facilities might apply in evaluating the attractiveness of a price-responsive (as opposed to reliability) load shed or shift. The research seeks to build on lessons from the successful implementation of DR in the commercial sector as well as knowledge acquired by the CEC, LBNL, and others concerning the energy use patterns and DR potential for California industry.

The goal of the DRRC industrial research is to facilitate deployment of industrial OpenADR that is economically attractive and technologically feasible and to increase DR reliability and effectiveness. This study is focused on several key research questions, provided below.

\section{Wastewater Treatment Facilities Key Research Questions}

\section{Where is the potential to shed or shift electricity use in wastewater treatment facilities?}

- Which end uses have the greatest potential to shed or shift during peak periods?

2. What is the functional capability of wastewater treatment facilities to implement OpenADR?

- What are the control gaps and the associated cost of implementing OpenADR?

3. What is the role of wastewater OpenADR in the state's goal to provide reliable and climate-friendly electricity at a reasonable cost to California consumers?

- Does participation in OpenADR by wastewater treatment facilities assist in promoting load management and energy efficiency in these facilities?

The DRRC's industrial sector research includes several additional topics that are not specifically addressed in this study. Those include: What are the market and operational barriers to the implementation of reliability and price-responsive DR in wastewater treatment facilities? Do wastewater treatment facility energy managers understand economic and societal benefits of DR? What roles do price and incentives have in the decision-making process? What are the areas of tension between DR and wastewater treatment operations? What are the market trends in industrial controls that support OpenADR? Do advances in control technologies make specific sectors or systems attractive candidates for OpenADR? What are the technology gaps that might benefit from public R\&D?

\section{Benefit to California}


This report focuses on energy efficiency and OpenADR applications within wastewater treatment facilities because energy consumption in wastewater treatment facilities represents a significant fraction of industrial facilities' operating expenses and account for some of the largest electrical loads in industrial processes. In the United States, estimates for energy use in water and wastewater treatment range from 75,000 to 100,000 GWh annually (Consortium for Energy Efficiency 2006; Environmental Protection Agency 2008). Within California, water and wastewater treatment comprises $5 \%$ of total energy consumption (Fuller 2003). In the next 15 years, loads will increase by $20 \%$ due to increasing populations and more stringent regulations (Environmental Protection Agency 2008). Pumps and aeration systems in wastewater treatment facilities contribute about $75 \%$ of the total energy use (Department of Environmental Protection Bureau of Land \& Water Quality 2002). Installing variable frequency drives (VFD) on blower equipment typically lowers energy use from 10 to $20 \%$, which can lead to considerable reduction in energy use and demand (Hemert 2006). By replacing existing equipment with high-efficiency equipment systems and installing VFDs, large reductions in state energy use and demand can be made.

\section{Report Organization}

This section describes the context, rationale, and potential for demand response in wastewater treatment facilities, research scope and key questions, and the benefit to California.

Section 2, Characteristics of Wastewater Processing Industries, introduces municipal and industrial wastewater treatment facilities.

Section 3, Nature of the Wastewater Stream, describes the characteristics of wastewater streams.

Section 4, Energy Use in Wastewater Treatment Facilities, summarizes the facility energy use and demand in wastewater treatment facilities.

Section 5, Wastewater Treatment Processes, details the wastewater treatment process and equipment energy use.

Section 6, Controls Systems, provides an overview of control systems and their applications to wastewater treatment facilities

Section 7, Energy Efficiency and Demand Response Opportunities, outlines the potential for energy efficiency and demand response measures.

Section 8, Case Studies, describes several California case studies

Section 9, Conclusions, provides conclusions

Section 10, References, lists references. 



\subsection{Characteristics of Wastewater Processing Industries}

Between 75,000 to 100,000 GWh per year is used to treat water and wastewater in municipal facilities, which comprises about $3 \%$ of U.S. annual energy consumption (Electric Power Research Institute 1994). According to the Environmental Protection Agency's (EPA) 2004 Clean Watersheds Needs Survey, there are 852 municipal wastewater treatment facilities in California and 21,540 in the United States (Environmental Protection Agency 2004). The EPA's 2008 Energy Management Guidebook for Wastewater and Water Utilities, states that there are 15,000 wastewater treatment facilities in the United States, including 6,000 municipal wastewater treatment systems (Environmental Protection Agency 2008). The reason for this discrepancy seems to be in the way the two reports count individual plants within a wastewater treatment facility.

Wastewater treatment is peripheral to the core business of major electricity-using industries in California and often located at a remote location from industrial facilities. As a result, wastewater treatment is an often overlooked area for energy efficiency and demand response. However, municipal wastewater treatment facility managers have developed a set of best practices that could be applicable in improving the energy efficiency and demand response readiness of key industrial sectors in California (California Energy Commission 2003; California Energy Commission 2003; Pacific Gas and Electric Company 2006). This study analyzes the energy use and assesses the potential for open automated demand response in municipal wastewater treatment facilities and four key California industries: food processing, petroleum refining, electronics, and cement manufacturing.

Food Processing: The food processing industry in California is highly diversified, comprising of more than 3,000 plants processing commodities (California Institute of Food and Agricultural Research 2006). California's food processing industries are the third largest industrial energy users in the state (California Energy Commission 2008). California is first in the nation in production of milk, fruits, and vegetables; fifth in meat; and tenth in grains (California Institute of Food and Agricultural Research 2006). Water is used throughout the production process for food cleaning, sanitizing, peeling, cooking, and cooling (Phillips 1997). It is also used as a conveyor medium to transport food materials through each process (Phillips 1997). This report will focus on three main subsectors of food manufacturing: meat and poultry products, fruit and vegetable products, and dairy products.

Petroleum Refining: California is the third largest manufacturer of petroleum products in the United States (California Energy Commission 2008). The petroleum refining industry is the largest energy consumer in California's manufacturing sector (California Energy Commission 2008). It is the largest industrial consumer of electricity and the second largest industrial consumer of natural gas in California (California Energy Commission 2008). The petroleum and coal products manufacturing subsector is responsible for transforming crude petroleum and coal into usable products (U.S. Census Bureau 2002). The refining process is energy intensive and involves separating crude petroleum into 
component products (U.S. Census Bureau 2002). These component products include liquefied petroleum gas, gasoline, kerosene, aviation fuel, diesel fuel, fuel oils, lubricating oils, and feedstocks for the petrochemical industry (Benyahia 2006). Petroleum refining uses large quantities of water for cooling systems, desalting water, stripping steam, and maintenance (Mohamed Al Zarooni and Walid Elshorbagy 2006). Due to the chemical nature of refinery wastewater, treatment can be complex and challenging (Benyahia 2006).

Electronics: The electronics industry is characterized by its wide ranging use of chemicals, raw materials, and processes in order to manufacture numerous electronic components and products (U.S. Census Bureau 2002). These products include computers, computer peripherals, and communications equipment as well as the components needed to manufacture these products such as semiconductors, printed circuit boards, and printed wiring assemblies (U.S. Census Bureau 2002). The computer and electronic industry is one of the most rapidly growing industries in California, with semiconductor manufacturing contributing to over 30\% of California's total computer and electronic shipments (California Energy Commission 2008). Semiconductor manufacturing is highly energy intensive, with electricity accounting for 40-60\% of facility operating costs (California Energy Commission 2008).

Cement Manufacturing: California cement production accounts for between 10-15\% of U.S. cement-production and is the largest cement producing state (Coito 2000). Cement manufacturing includes manufacturing Portland, natural, masonry, pozzalanic, and other hydraulic cements (U.S. Census Bureau 2002). However, in recent years, there has been increased investment in facilities that manufacture cement using dry processing rather than the more energy-intensive wet processing (Portland Cement Association 2003). This has reduced overall water use in the industry and accordingly reduced the amount of wastewater needing treatment.

Municipal Wastewater Treatment Facilities: In the United States, water and wastewater treatment facilities account for 35\% of municipal energy use, accounting for approximately 75,000 to 100,000 GWh annually (Consortium for Energy Efficiency 2006; Environmental Protection Agency 2008). For most municipalities, water and wastewater divisions are the largest consumers of energy (Ontario Centre for Municipal Best Practices 2006). Energy use varies depending on the population, source and quality of the wastewater, process type, size, and age of the facility (Environmental Protection Agency 2008). Most municipal wastewater treatment facilities have implemented or can implement energy saving methods that will greatly reduce operating costs and improve wastewater treatment efficiency. 


\subsection{Nature of the Wastewater Stream}

Municipal and industrial wastewater treatment facilities are responsible for carrying out inspection, surveillance, and monitoring procedures to ensure wastewater is in compliance with the conditions of federal or state permits (Environmental Protection Agency 2004). There are three categories of regulatory requirements for wastewater discharge from industries. The first category are industry-specific wastewater regulations set up by the EPA effluent guidelines (Wang 2005). The second category includes pretreatment discharge requirements that are established by both federal and municipal wastewater treatment facilities that combine and treat both industrial and domestic wastes in publicly owned treatment works (Wang 2005). The third category is effluent limitations that are released into surface waters without first going through a Publicly-Owned Treatment Works or municipalities. These direct discharges are also required to obtain a permit from the EPA.

Federal regulations for industrial wastewater discharges set technology-based limitations for industrial and municipal facilities. The reason for technology-based effluent limitation is to require a minimum level of treatment for sources while allowing the discharger to use any available control techniques to meet the limitations (Environmental Protection Agency 2008). The types of technology-based limitations include best practicable technology, best control technology, best available control technology economically achievable, new source performance standards, pretreatment standards for existing sources, and pretreatment standards for new sources (Environmental Protection Agency 2008).

Discharge limitations set by local authorities take into account the conditions specific to the treatment system and discharge permit and may be more stringent than federal limitations. The Regional Water Quality Control Board regulates discharges that could affect California's surface, coastal, and groundwater. Wastewater treatment facilities are required to file a National Pollutant Discharge Elimination System (NPDES) permit application with the appropriate Regional Water Quality Control Board. The state of California is divided into nine regions: North Coast, San Francisco Bay, Central Coast, Los Angeles, Central Valley, Lahontan, Colorado River, San Diego, and Santa Ana. Example wastewater discharge requirements for the San Francisco Bay and Los Angeles regions are shown below in Tables 1 and 2 . 
Table 1. San Francisco Region Effluent Monitoring Requirements Conventional Effluent Limitations

\begin{tabular}{|c|c|c|c|}
\hline Parameter & Units & $\begin{array}{c}\text { Weekly } \\
\text { Avg. }\end{array}$ & $\begin{array}{c}\text { Monthly } \\
\text { Avg }\end{array}$ \\
\hline $\mathrm{BOD}_{5}$ at $68^{\circ} \mathrm{F}\left(20^{\circ} \mathrm{C}\right)$ & $\mathrm{mg} / \mathrm{L}$ & 45 & 30 \\
\hline Percent Removal of $\mathrm{BOD}_{5}$ & $\%$ & -- & 85 \\
\hline $\begin{array}{c}\text { Total Suspended Solids } \\
\text { (TSS) }\end{array}$ & $\mathrm{mg} / \mathrm{L}$ & 45 & 30 \\
\hline TSS removal & $\%$ & -- & 85 \\
\hline pH & $\mathrm{pH}$ & $6.0-9.0$ & $6.0-9.0$ \\
\hline Oil and Grease & $\mathrm{mg} / \mathrm{L}$ & -- & 10 \\
\hline
\end{tabular}

Source: California Regional Water Quality Control Board San Francisco Bay Region (2008).

NPDES No. CA0038539.

Table 2. Los Angeles Region General Effluent Limitations Discharges of Non-process Wastewater to Surface Waters

\begin{tabular}{|c|c|c|c|}
\hline Constituents & Units & $\begin{array}{c}\text { Discharge } \\
\text { Limitations } \\
\text { Daily Max }\end{array}$ & $\begin{array}{c}\text { Discharge } \\
\text { Limitations } \\
\text { Monthly Avg }\end{array}$ \\
\hline Total Suspended Solids & $\mathrm{mg} / \mathrm{L}$ & 150 & 50 \\
\hline Turbidity & $\mathrm{NTU}^{*}$ & 150 & 50 \\
\hline $\mathrm{BOD}_{5} 68^{\circ} \mathrm{F}\left(20^{\circ} \mathrm{C}\right)$ & $\mathrm{mg} / \mathrm{L}$ & 30 & 20 \\
\hline Oil and Grease $_{\text {Settleable Solids }}$ & $\mathrm{mg} / \mathrm{L}$ & 15 & 10 \\
\hline Sulfides & $\mathrm{mL} / \mathrm{L}$ & 0.3 & 0.1 \\
\hline Residual Chlorine & $\mathrm{mg} / \mathrm{L}$ & 1.0 & -- \\
\hline
\end{tabular}

Source: California Regional Water Quality Control Board Los Angeles Region (2004). General NPDES Permit No. CAG994003.

${ }^{*}$ Nephelometric Turbidity Units

Federal and local permits typically regulate conventional pollutants such as biological oxygen demand, suspended solids, fecal coliform, pH, oil, and grease (Environmental Protection Agency 2002). Total dissolved solids, nitrogen, phosphorus, heavy metals, and organics are also importance measures of the wastewater quality and are used in establishing wastewater effluent regulations. These common components of wastewater are described below.

Dissolved oxygen (DO): DO indicates the amount of oxygen present in water. Dissolved oxygen is necessary for microorganisms to breakdown organic material present in the water. DO concentrations vary daily and seasonally and tend to be lower during summer months because biochemical reactions use more oxygen in higher temperatures (Metcalf \& Eddy Inc. 2003). Further, overall oxygen levels are lower during summer months due to decreased stream flows (Metcalf \& Eddy Inc. 2003). 
Biological oxygen demand $\left(B O D_{5}\right)$ : BOD is an estimate of the amount of oxygen required for the decomposition of organic matter under aerobic conditions (Metcalf \& Eddy Inc. 2003). When large amounts of organic matter are present, the decomposition process consumes oxygen and reduces the amount available for aquatic animals (Metcalf \& Eddy Inc. 2003). This number is determined by measuring the depletion of dissolved

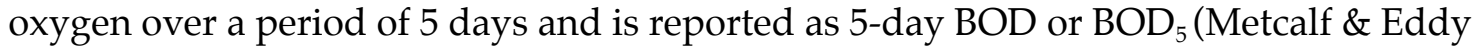
Inc. 2003).

Chemical oxygen demand (COD): COD is an estimate of the total organic matter in wastewater and includes slowly biodegradable and recalcitrant organic compounds not degraded microbially during the duration of the $\mathrm{BOD}_{5}$ test. COD is usually higher than $\mathrm{BOD}_{5}$ and only requires a few hours to determine (Metcalf \& Eddy Inc. 2003).

Total suspended solids (TSS): TSS are particles that cannot be collected by a filter and that remain suspended in the effluent even after treatment (Massachusetts Water Resources Authority 2007). These solid pollutants may come from urban runoff and agricultural land, industrial wastes, bank erosion, bottom feeders, and algae growth (North Dakota Department of Health 2005).

Total dissolved solids: Total dissolved solids are the inorganic and organic particles of a specific pore size that pass through a filter and are measured after being dried at a specified temperature (Metcalf \& Eddy Inc. 2003). Total dissolved solids may lead to buildup in pipes, reducing the efficiency of water filters, and can pose a hazard to marine life if concentrations exceed regulation levels (Water Systems Council 2007).

Fecal coliform: Fecal coliform are pathogenic organisms associated with feces and are disease-producing organisms (Metcalf \& Eddy Inc. 2003).

pH levels: $\mathrm{pH}$ levels are a measure of the effluent's acidity or basicity. Large fluctuations in $\mathrm{pH}$ levels will have adverse effect on marine life (Massachusetts Water Resources Authority 2007).

Fats, Organics, Grease: Fatty organic material from animals, vegetables, and petroleum are not easily broken down and can increase BOD $_{5}$ levels (National Small Flows Clearinghouse 1997). These materials can also cause system failures by clogging pipes and aggravating pumps (National Small Flows Clearinghouse 1997).

Nitrogen, phosphorus, heavy metals, organics: Nutrients such as nitrogen and phosphorus, heavy metals, or organics can be harmful if the receiving water is sensitive to its impacts (William Nazaroff and Lisa Alvarez-Cohen 2004). Nitrogen and phosphorus can stimulate the growth of aquatic plants, which in turn can impair the life of other aquatic species.

\subsection{Food Processing}

Food processing is a water-intensive operation (Phillips 1997). Fruit and vegetable processors in California use 110 billion liters (30 billion gallons) of water per year to make their products and maintain their facilities (Neenan 2008). In the United States, meat and poultry processing industries use about 570 billion liters (150 billion gallons) of water annually (Waste Reduction Resource Center 2008). Water is used throughout the 
production process for food cleaning, sanitizing, peeling, cooking, and cooling (Phillips 1997). It is also used as a conveyor medium to transport food materials through each process. Wastewater from food processing industries is highly variable in composition and volume, depending on the product, scale of operation, weather, and season (Phillips 1997). The level of wastewater generation also varies among processing facilities due to increased efforts to minimize water use and to reduce the cost of wastewater treatment (Environmental Protection Agency 2004).

Wastewater Characteristics: In general, food processing wastewater is comprised of high concentrations of TSS, COD, $\mathrm{BOD}_{5}$, fats, organics, grease, and nutrients such as nitrogen and phosphorus (Phillips 1997). Fruit and vegetable processing wastewater usually contain high levels of suspended solids, organic sugars and starches, and residual pesticides (USAEP 2008). However, food processing wastewater is generally characterized as nontoxic because it contains few hazardous compounds that are listed under EPA's Toxic Release Inventory (California Green Solutions 2007). The waste stream from meat processing facilities is more difficult to treat than the wastewater from fruit and vegetable processing because it contains large amounts of blood, which results in extremely high $\mathrm{BOD}_{5}$ (USAEP 2008). Meat processing wastes also include soft tissue, bone, urine and feces, soil, and various cleaning and sanitizing compounds (Environmental Protection Agency 2004). Pathogenic organisms such as salmonella, intestinal bacteria, and other fecal coliforms are also major contaminants in wastewater from livestock processing facilities (USAEP 2008). Table 3 presents the generated and discharged characteristic of wastewater from a rendering plant.

Table 3. Wastewater Characterization of Typical Rendering Plant

\begin{tabular}{|c|c|c|}
\hline Parameter & $\begin{array}{c}\text { Generated } \\
\text { Wastewater }(\mathbf{m g} / \mathbf{L})\end{array}$ & $\begin{array}{c}\text { Discharged Wastewater } \\
(\mathbf{m g} / \mathbf{L})\end{array}$ \\
\hline Chemical oxygen demand $(\mathrm{mg} / \mathrm{L})$ & 123,000 & 8,000 \\
\hline $\mathrm{BOD}_{5}(\mathrm{mg} / \mathrm{L})$ & 80,000 & 5,100 \\
\hline TSS $(\mathrm{mg} / \mathrm{L})$ & 8,400 & 268 \\
\hline Fat and other greases $(\mathrm{mg} / \mathrm{L})$ & 3,200 & 116 \\
\hline Metals (average zinc) $(\mathrm{mg} / \mathrm{L})$ & -- & 0.68 \\
\hline $\begin{array}{c}\text { Fecal coliform bacteria }(\text { Colony forming } \\
\text { units (CFU)/100 } \mathrm{mL})\end{array}$ & $2.5 \times 108 \mathrm{CFU} / \mathrm{mL}$ & $4.5 \times 104 \mathrm{CFU} / \mathrm{mL}$ \\
\hline
\end{tabular}

Source: Environmental Protection Agency. 40 CFR Part 432. Technical Development Document for the Final Effluent Limitations Guidelines and Standards for the Meat and Poultry Products Point Source Category. 2004.

Regulations: $\mathrm{BOD}_{5}$ and $\mathrm{pH}$ levels are of primary concern in food processing wastewater and require regulatory measures to ensure the health of the receiving body of water. Regulations differ for different treatment processes due to the wide variations in the chemical and physical composition of the wastewater stream and the different methods of treatment at the facility. 
Tables 4-6 show federal effluent regulations for meat and poultry processing, fruit and vegetable processing, and dairy processing.

Table 4. Federal Effluent Limitation Guidelines for Slaughterhouses*

\begin{tabular}{|c|c|c|}
\hline \multirow{2}{*}{$\begin{array}{c}\text { Effluent } \\
\text { characteristic }\end{array}$} & \multicolumn{2}{|c|}{ Effluent limitations (kilograms per 1,000 kg of raw material) } \\
\cline { 2 - 3 } & Maximum for any 1 day & $\begin{array}{c}\text { Average of daily values for } \mathbf{3 0} \\
\text { consecutive days shall not exceed- }-\end{array}$ \\
\hline $\mathrm{BOD}_{5}$ & 0.24 & 0.12 \\
\hline Fecal coliform & $\begin{array}{c}400 \text { most probable number or } \\
\text { colony forming units per 100 mL }\end{array}$ & 0.06 \\
\hline Oil and Grease & 0.12 & 0.06 \\
\hline TSS & 0.40 & 0.20 \\
\hline
\end{tabular}

Source: Environmental Protection Agency. 40 CFR Part 432. Meat and Poultry Products Point

Source Category. 2006.

${ }^{*}$ Facilities that slaughter no more than 23 million kilograms (50 million pounds) per year

Table 5. Federal Effluent Limitations Guidelines for Canned and Preserved Tomatoes*

\begin{tabular}{|c|c|c|}
\hline Effluent Characteristics & \multicolumn{2}{|c|}{ Effluent Limitations (kilograms per 1,000 kg of raw material) } \\
\cline { 2 - 3 } & Maximum for any 1 day & $\begin{array}{c}\text { Average of daily values for } \\
\mathbf{3 0} \text { consecutive days shall } \\
\text { not exceed -- }\end{array}$ \\
\hline $\mathrm{BOD}_{5}$ & 1.21 & 0.71 \\
\hline $\mathrm{TSS}$ & 2.15 & 1.48 \\
\hline $\mathrm{pH}$ & $6.0-9.0$ & $6.0-9.0$ \\
\hline
\end{tabular}

Source: Environmental Protection Agency. 40 CFR Part 407. Canned and Preserved Fruits and Vegetables Processing Point. 2006.

*under best practicable control technologies currently available

Table 6. Federal Effluent Limitations for Dairy Processing Facilities*

\begin{tabular}{|c|c|c|}
\hline \multirow{2}{*}{ Effluent Characteristic } & \multicolumn{2}{|c|}{ Effluent Limitations (kilograms per $\mathbf{1 , 0 0 0 ~ k g ~ o f ~ \mathbf { B O D } _ { 5 } \text { input) }}$} \\
\cline { 2 - 3 } & Maximum for any $\mathbf{1}$ day & $\begin{array}{c}\text { Average of daily values for } \\
\mathbf{3 0} \text { consecutive days shall } \\
\text { not exceed- }\end{array}$ \\
\hline $\mathrm{BOD}_{5}$ & 0.475 & 0.190 \\
\hline $\mathrm{TSS}$ & 0.713 & 0.285 \\
\hline $\mathrm{pH}$ & $6.0-9.0$ & $6.0-9.0$ \\
\hline
\end{tabular}

Source: Environmental Protection Agency. 40 CFR Part 405 Dairy Products Processing Point Source Category. 2008.

* For facilities receiving more than $68,000 \mathrm{~kg} /$ day $(150,000 \mathrm{lb} /$ day) of milk equivalent under best practicable control technology currently available 


\subsection{Petroleum Refining}

The petroleum refining industry typically spends $50 \%$ of the operating costs on energy and is the single largest industrial energy user in the United States (McInerney 1995; Energy Information Administration 2002). California is home to 20 of the 146 operating petroleum refineries in the United States and California produces 2,007,188 barrels of crude oil per day, 12\% of total U.S. production (Energy Information Administration 2009). In 2001, refineries in California consumed nearly 500 trillion Btus of energy, with over $67 \%$ in the form of natural gas or other fuels (Energetics Incorporated 2004). The wastewater from this industry presents challenges to wastewater treatment facilities due to the corrosive nature of dissolved salts in the water. Industrial wastewater containing dissolved metal ions such as copper, cadmium, and lead will eventually cause metallic equipment failure and also lead to water pollution that is detrimental to stream health and marine life (Nosier 2003). The refinery must be shut down and cleaned regularly due to the corrosive composition of the wastewater (S.A. Jenabali Jahromi and A. Janghorban 2004). The specific volume and composition of wastewater generated by petroleum refineries depend on the process used to manipulate crude oil. Findings suggest that there are substantial opportunities to reduce energy consumption in the petroleum refining industry while maintaining the quality of the products produced (McInerney 1995).

Wastewater Characteristics: Petroleum refineries use large quantities of water for cooling systems, desalting water, stripping steam, and flushing during maintenance and shut down (Mohamed Al Zarooni and Walid Elshorbagy 2006). Hydrocarbons, phenols, ammonia, and sulfides are typically found in the wastewater, as well as wash water, alkaline, and acid waste neutralization water that are associated with the treatment of crude oil (The Hendrix Group Inc. 2005). On average, when cooling water is recycled, $3.5-5 \mathrm{~m}^{3}$ of wastewater are generated per ton of crude oil (Mohamed Al Zarooni and Walid Elshorbagy 2006). The characteristics of polluted wastewater from a petroleum refinery are listed in Table 7.

Table 7. Composition of Untreated Petroleum Refinery Wastewater

\begin{tabular}{|c|c|}
\hline Pollutants & Guideline Value (mg/L) \\
\hline BOD $_{5}$ & $150-250$ \\
\hline COD & $300-600$ \\
\hline Phenol levels & $20-200$ \\
\hline Oil levels & $100-300$ in desalter water \\
& 5,000 in tank bottoms \\
\hline Benzene levels & $1-100$ \\
\hline Benzo(a)pyrene & $1-100$ \\
\hline Chrome & $0.1-100$ \\
\hline Lead & $0.2-10$ \\
\hline
\end{tabular}

Source: Benyahia, F., M. Abdulkarim, A. Embaby, and M. Rao (2006). Refinery Wastewater Treatment: A True Technological Challenge. The Seventh Annual U.A.E. University Research Conference. U.A.E. University.

Regulations: Refinery wastewater usually requires a combination of treatment methods to remove oil and contaminants before discharge. Regulatory requirements vary 
depending on the complexity of the petroleum refining process. Table 8 displays the effluent levels required of petroleum refining discharges attainable by best practicable control technology currently available. Feedstock refers to crude oil and natural gas liquids fed to the topping units (Environmental Protection Agency 2006).

Table 8. Federal Effluent Regulations for Petroleum Refining*

\begin{tabular}{|c|c|c|}
\hline Pollutant & $\begin{array}{c}\text { Maximum for } 1 \text { day } \\
\left(\mathrm{kg} / 1000 \mathrm{~m}^{3} \text { of feedstock }\right)\end{array}$ & $\begin{array}{c}\text { Avg daily values for } 30 \\
\text { consecutive days shall not } \\
\text { exceed (kg/1000 } \mathrm{m}^{3} \text { of } \\
\text { feedstock) }\end{array}$ \\
\hline $\mathrm{BOD}_{5}$ & 22.7 & 12.0 \\
\hline TSS & 15.8 & 10.1 \\
\hline COD & 117.0 & 60.3 \\
\hline Oil and Grease & 6.9 & 3.7 \\
\hline Phenolic compounds & 0.168 & 0.076 \\
\hline Ammonia & 2.81 & 1.27 \\
\hline Sulfide & 0.149 & 0.068 \\
\hline Total chromium & 0.345 & 0.20 \\
\hline Hexavalent chromium & 0.028 & 0.012 \\
\hline $\mathrm{pH}$ & $6.0-9.0$ & $6.0-9.0$ \\
\hline
\end{tabular}

Source: Environmental Protection Agency. 40 CFR Part 419 Petroleum Refining Point Source Category. 2006

${ }^{*}$ Under best practicable control technology available

\subsection{Electronics}

The electronics industry is characterized by its wide ranging use of chemicals, raw materials, and processes in order to manufacture numerous electronic components and products. Techniques for wastewater treatment are specific to the manufacturing process and the nature of the contaminant. The semiconductor industry is one of the fastest growing electronic industries in California, and also is one of the most energy-intensive of the electronics manufacturing industries (California Energy Commission 2008).

Semiconductors are found largely in computer equipment, machineries, automobiles, and other electronics. An integral part of the semiconductor and flat-panel display manufacturing is the cleaning of silicon wafers by removal of photoresist, a photosensitive organic part of a silicon wafer (ANON Incorporated 1999). Hot liquid chemicals are needed to remove the photoresist and can result in large amounts of hazardous and toxic chemical wastes. The cleaning process is typically a two-step process that involves large amounts of liquid chemicals. An alternative cleaning method which uses sulfur trioxide gas $\left(\mathrm{SO}_{3}\right)$ greatly reduces the volume of hazardous operating chemicals introduced to the wastewater, potentially by over $99 \%$ (ANON Incorporated 1999). This reduction of chemicals in the waste stream also greatly reduces the amount of energy needed to treat the wastewater.

Wastewater Characteristics: Effluent from semiconductor manufacturing include hydrofluoric, hydrochloric, sulfuric acids, organic solvents, phosphorous oxychloride, acetate, metals, and fluorides (International Finance Corporation 2007). High levels of 
dissolved ammonia from semiconductor industry wastewater can be a major threat to the environment and the facility's wastewater discharge limit (Siemens Water Technologies 2005). High prevalence of hazardous and toxic chemical wastes is likely to result from production in the semiconductor industry. Chemical mechanical polishing processes are characterized by high content of suspended solids having submicron particle sizes, high turbidity, and high conductivity (Yang 2002).

Regulations: Effective treatment is required to treat wastewater from the electronics industry due to the inorganic and corrosive nature of the wastewater content. Inorganic particles containing nanosized metal colloid can be difficult to remove (Hosokawa 2007). Therefore, regulations are critical for maintaining the health of the marine life in the river or stream. In the electronics industry, wastewater reclamation and reuse is common in the manufacturing process. Table 9 shows the effluent levels required for the processed wastewater from the semiconductor industry under best practicable control technology currently available.

Table 9. Federal Effluent Regulations for the Semiconductor Industry

\begin{tabular}{|c|c|c|}
\hline $\begin{array}{c}\text { Pollutant or pollutant } \\
\text { property }\end{array}$ & $\begin{array}{c}\text { Maximum for any } \mathbf{1} \text { day } \\
\text { (mg/L) }\end{array}$ & $\begin{array}{c}\text { Average of daily values for } \mathbf{3 0} \\
\text { consecutive days (mg/L) }\end{array}$ \\
\hline Total Toxic Organics & 1.37 & - \\
\hline $\mathrm{pH}$ & $6.0-9.0$ & $6.0-9.0$ \\
\hline
\end{tabular}

Source: Environmental Protection Agency (2008). Section B. Clean Water Act Requirements.

\subsection{Cement Manufacturing}

Cement manufacturing facilities, such as the those that produce Portland cement, generate little to no water effluent since most of the input water is used in the manufacturing of cement or recycled (International Finance Corporation 2007). Water that is used in wet process blending is evaporated, and cooling water is reused through a closed-loop system (Canadian Terrestrial Ecosystem Model 2000). Unlike the wet process in which water is added to the raw mixture then evaporated, the dry process uses exhaust kiln gas to dry the raw material thereby eliminating excess use of water (Canadian Terrestrial Ecosystem Model 2000).

Wastewater Characteristics: Effluent largely contains dissolved solids, such as potassium and sodium hydroxide and suspended solids (Egyptian Environmental Affairs Agency 2005). Another major source of water pollution for the cement industry is alkali present in wastewater, which comes from kiln dust. Cement kiln dust is fine-grained, solid, highly alkaline waste removed from cement kiln exhaust gas by air pollution control devices and can be recycled in the production process (Environmental Protection Agency 2008). Kiln dust is a key indication of the quality of wastewater discharge from cement facilities because it raises the $\mathrm{pH}$ level and adds significant quantities of suspended solids, sulfate, and potassium to the effluent (Canadian Terrestrial Ecosystem Model 2000). Potassium, sodium hydroxide, chlorides, sulfates, and suspended solids are also key pollutants in the cement manufacturing wastewater stream (Australian Government 2008). 
Regulations: Although most of the water used in cement production is recycled or entirely consumed in the manufacturing process, some pollutants are present in the effluent and must be treated before it can be released into the environment. Table 10 displays the effluent limitation guidelines provided by the Code of Federal Regulations (CFR) if the effluent was treated from best practicable pollutant control technology.

Table 10. CFR Effluent Limitation Guidelines for Cement Manufacturing

\begin{tabular}{|c|c|}
\hline Effluent Characteristics & Effluent Limitations maximum for any $\mathbf{1}$ day (kg/kkg of product) \\
\hline TSS & 0.005 \\
\hline Temperature & Not to exceed 3 deg. C rise above inlet temperature \\
\hline $\mathrm{pH}$ & $6.0-9.0$ \\
\hline
\end{tabular}

Source: Environmental Protection Agency. 40 CFR Part 411 Cement Manufacturing Point Source Category. 2006.

\subsection{Municipal Wastewater Treatment Facilities}

There are four basic types of municipal wastewater: residential wastewater, industrial wastewater, infiltration and inflow to the sewage system, and storm runoff (William Nazaroff and Lisa Alvarez-Cohen 2004).

Wastewater characteristics: Wastewater characterization is important in the design of treatment and disposal processes. The physical, chemical, and biological characteristics of municipal wastewater vary throughout the day. The principal factors affecting loading variations are community residents' habits, seasonal conditions, and industrial activities (Metcalf \& Eddy Inc. 2003). The characteristics of a typical untreated, mediumstrength wastewater are shown in Table 11. The data are based on an average flow of 450 liters (120 gal) per capita*day and include commercial, residential, and industrial sources (Metcalf \& Eddy Inc. 2003).

Table 11. Typical Composition of Untreated, Medium Strength Residential Wastewater

\begin{tabular}{|c|c|}
\hline Contaminant & $\begin{array}{c}\text { Concentration (mg/L, except where } \\
\text { noted) }\end{array}$ \\
\hline Total solids & 720 \\
\hline Total dissolved solids & 500 \\
\hline Volatile total dissolved solids & 200 \\
\hline Suspended solids & 210 \\
\hline Volatile suspended solids & 160 \\
\hline Settleable solids & $10(\mathrm{~mL} / \mathrm{L})$ \\
\hline BOD $_{5}\left(68^{\circ} \mathrm{F} / 20^{\circ} \mathrm{C}\right)$ & 190 \\
\hline Total organic carbon orgen demand (COD) & 140 \\
\hline Nitrogen & 430 \\
\hline Phosphorus & 40 \\
\hline Chlorides & 7 \\
\hline Sulfates & 50 (above level in water supply) \\
\hline Oil and Grease & 30 (above level in water supply) \\
\hline Total Coliform & 90 \\
\hline
\end{tabular}




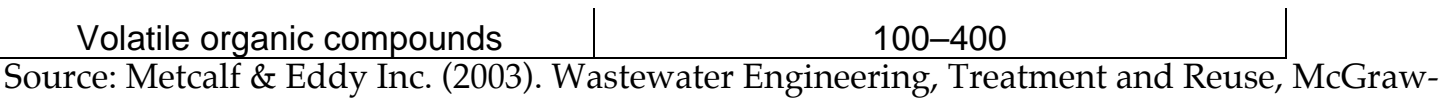
Hill.

Regulations: State and federal agencies seek to improve the effectiveness and treatment of wastewater to improve the quality of surface waters. Discharges from industrial wastewater to a sanitary sewer are called indirect discharges and are regulated by industrial pretreatment limitations. A typical municipal treatment facility removes $\mathrm{BOD}_{5}$ and TSS from the wastewater by secondary treatment. Secondary treatment standards provided by the EPA are shows in Table 12.

Table 12. Secondary Treatment Standards for Municipal Wastewater

\begin{tabular}{|c|c|c|}
\hline Parameter & 30-day Average & 7-day Average \\
\hline $\mathrm{BOD}_{5}$ & $30 \mathrm{mg} / \mathrm{L}$ & $45 \mathrm{mg} / \mathrm{L}$ \\
\hline $\mathrm{TSS}$ & $30 \mathrm{mg} / \mathrm{L}$ & $45 \mathrm{mg} / \mathrm{L}$ \\
\hline $\mathrm{pH}$ & $6.0-9.0$ & - \\
\hline Removal & $85 \% \mathrm{BOD}_{5}$ and TSS & - \\
\hline
\end{tabular}

Source: Environmental Protection Agency (1996). U.S. EPA NPDES Permit Writer's Manual. 1996. 


\subsection{Energy Use in Wastewater Treatment Facilities}

Electrical energy usage is high in wastewater treatment processes and accounts for a significant portion of overall operating expenses (Cho 1984). Between 75,000 to 100,000 GWh per year of electricity is used to treat water and wastewater in municipal facilities, which comprises about 3\% of U.S. annual energy consumption (Environmental Protection Agency 2006). The California Energy Commission (CEC) reported that wastewater treatment in California used approximately 1,600 GWh of electricity in 1995 and 2,012 GWh in 2001 (California Energy Commission 2005). The CEC forecasted that, given California's continued growth, energy use in wastewater treatment is likely to become significantly higher (California Energy Commission 2005). In the next 15 years, EPA estimates that loads in water and wastewater facilities will increase by $20 \%$ due to increasing populations and more stringent regulations (Environmental Protection Agency 2008). In order to assess the potential for demand response in wastewater treatment facilities, it is important to understand the magnitude of energy use and demand in wastewater treatment facilities, the daily and seasonal load patterns, and the role of energy-intensive equipment in the wastewater treatment process.

Load variation in wastewater treatment facilities depends on many factors including seasonal and daily load patterns, the type of industry, location, and population size (Tchobanoglous 2002). For example, many manufacturing facilities have fairly constant wastewater flowrates during daily production, but these can change dramatically during cleanup and shutdown (Tchobanoglous 2002). Wastewater flowrates vary in this manner depending on the time of day, day of the week, season of the year, or sometimes depending upon the nature of the discharge (Tchobanoglous 2002). Peak demand, loadfactor, and other energy use parameters for municipal and industrial wastewater treatment facilities will also vary according to site specific parameters such as size, treatment type, and equipment, as well as regulatory measures that the facility is required to follow.

Wastewater treatment facility energy demand is high during the summer months, particularly in areas with hot summers like Southern California (Natural Resources Defense Council 2004). The facility demand required to treat and transport wastewater is significant during the peak energy demand periods experienced by the electrical utilities (Natural Resources Defense Council 2004). This, combined with the characteristic energy-intensity of the wastewater treatment process, makes wastewater treatment facilities prime candidates for open automated demand response.

\subsection{Factors Impacting Energy Intensity in Wastewater Treatment Facilities}

In 2001, wastewater treatment facilities in California consumed 2,012 GWh of electricity (California Energy Commission 2005). Within these facilities, the energy intensity for water collection and treatment ranged from $290 \mathrm{kWh}$ per million liters $(1,100 \mathrm{kWh}$ per million gallons) to $1,200 \mathrm{kWh}$ per million liters $(4,600 \mathrm{kWh}$ per million gallons) (California Energy Commission 2005) with an average of $320 \mathrm{kWh}$ per million liters 
(1,200 kWh per million gallons) (Carns 2004). One of the reasons for this wide range is the variability in transporting and pumping wastewater. The average amount of electricity used for transporting and pumping wastewater from a residential or commercial area to a municipal wastewater treatment facility is $40 \mathrm{kWh}$ per million liters (150 kWh per million gallons), but this value can vary greatly depending on wastewater treatment facility topography, as well as system size and age (California Energy Commission 2005). Some wastewater collection systems rely on gravity to transport wastewater to a treatment facility, while others use energy-intensive pumps to lift or transfer the wastewater (California Energy Commission 2005). The energy utilized in wastewater treatment processes is largely dependent on facility size, type of processing, and efficiency levels of the equipment (Natural Resources Defense Council 2004). Another reason for the variability in wastewater treatment energy intensity is the dependence of energy use on the quality of the waste stream, the level of treatment required to meet regulations, and the treatment technologies used (California Energy Commission 2005). Table 13 shows the energy intensity of several California wastewater treatment facilities.

\begin{tabular}{|c|c|} 
Table 13. Energy Intensity of Wastewater Treatment Facilities \\
\hline Source of Data & $\begin{array}{c}\text { Energy Use } \\
\mathbf{k W h} / \mathbf{M L} \\
\mathbf{( k W h / M G )}\end{array}$ \\
\hline Inland Empire Utilities Agency & $785(2,971)$ \\
\hline City of Santa Rosa & $771(2.920)$ \\
\hline East Bay Municipal Utilities District & $529(2,001)$ \\
\hline $\begin{array}{c}\text { Metropolitan Water District } \\
\text { Methodology for Analysis of Energy Intensity in } \\
\text { California's Water Systems }\end{array}$ & $501(2,655)$ \\
\hline $\begin{array}{c}\text { Energy Benchmarking Secondary Wastewater } \\
\text { Treatment }\end{array}$ & $693(2,911)$ \\
\hline
\end{tabular}

Source: California Energy Commission. California's Water-Energy Relationship. 2005.

A New York State Energy Research and Development Authority (NYSERDA) study found that the national average energy intensity for wastewater treatment was $320 \mathrm{kWh}$ per million liters (1,200 kWh per million gallons) (Yonkin 2007). New York State's average energy use for treating wastewater was $282 \mathrm{kWh}$ per million liters $(1,067 \mathrm{kWh}$ per million gallons) for large facilities ( $>284$ million liters (75 million gallons) per day) and $990 \mathrm{kWh}$ per million liters $(3,749 \mathrm{kWh}$ per million gallons) for small facilities $(<4$ million liters (one million gallons) per day), with a statewide average of $357 \mathrm{kWh}$ per million liters (1,353 $\mathrm{kWh}$ per million gallons). This shows that the energy use in large facilities is much lower than the small facilities, and that large facilities process a significantly higher portion of wastewater, bringing the average to the lower end of the range. NYSERDA also reported that larger wastewater treatment facilities generally tend to be more energy efficient than smaller facilities. Further, larger facilities tend to use less energy for aeration processes than smaller facilities (NYSERDA 2006). However, there are significant opportunities for reducing energy use in small treatment systems (NYSERDA 2006; NYSERDA 2006; Yonkin 2007). 
Table 14. Comparison of Energy Use for Wastewater Treatment

\begin{tabular}{|c|c|c|c|}
\hline Size Category & $\begin{array}{c}\text { Energy Use } \\
\mathbf{k W h} / \mathbf{M L} \\
\mathbf{( k W h} / \mathbf{M G})\end{array}$ & $\begin{array}{c}\text { \% of Sector Wide } \\
\text { Energy Use }\end{array}$ & $\begin{array}{c}\% \text { of Sector Wide } \\
\text { Treatment } \\
\text { Capacity }\end{array}$ \\
\hline <4 MLD (<1MGD) & $990(3,749)$ & 10.3 & 3.8 \\
\hline 4-19 MLD (1-5 MGD) & $403(1,527)$ & 8.3 & 7.5 \\
\hline 19-76 MLD (5-20 MGD) & $394(1,490)$ & 14.2 & 13.1 \\
\hline $76-284$ MLD (20-75 MGD) & $413(1,562)$ & 27.0 & 23.8 \\
\hline$>284$ MLD (>75 MGD) & $282(1,067)$ & 40.0 & 51.8 \\
\hline
\end{tabular}

Source: Yonkin, M. C. Energy Smart Focus Program for NY's Water and Wastewater Sectors, Malcolm Pirnie and NYSERDA. 2007.

This remainder of this section outlines the energy use in four of California's key industries: food processing, electronics, cement manufacturing, and petroleum refining, as well as in municipal wastewater treatment facilities.

\subsubsection{Energy Use in Food Processing Facilities}

Energy consumption in the food processing industry is highly variable, because the water consumption rates vary greatly within different sectors of the food processing industry (Mannapperuma 1993). Water consumption rates fluctuate considerably depending on the scale of the plant, the age and type of processing, the level of facility control, and the type of process cleaning methods that use water (COWI Consulting Engineers and Planners 2000). Some facilities use Cleaning in Place systems for automatic cleaning in food processing facilities. This technology does not require major disassembly and assembly, and allows for maximum facility utilization, as well as the reduction of water use, cleaning solutions, and labor (GEA Process Engineering Inc.). Some sectors, such as the fruit and vegetable industry, show seasonal trends in water use, while other sectors, such as the dairy and meat processing industry, do not show seasonal variations in water use (Mannapperuma 1993).

In the meat and poultry sector, water is mainly used for watering and washing the livestock, washing of trucks, washing carcasses and by-products, and for cleaning and sterilizing equipment and process areas (COWI Consulting Engineers and Planners 2000). Most of the water that is consumed at these processes at the slaughterhouses becomes effluent (Mannapperuma 1993) and the most significant source of pollution comes from the rendering process (COWI Consulting Engineers and Planners 2000). Typical water consumption is between 2-15 cubic meters per ton of live carcass weight (70-530 cubic feet per ton) (COWI Consulting Engineers and Planners 2000).

In the fruit and vegetable sector, water is used for food cleaning, sanitizing, peeling, cooking, and cooling. It is also used as a conveyor medium to transport food materials through each process. Wastewater in this sector is highly variable in composition and volume, depending on the product, scale of operation, weather, and season (Phillips 1997). Tomato and peach industries use most of the water during summer month with the peak in August. Most of the fruit and vegetable industries follow trends similar to tomato and peach plants (Mannapperuma 1993). Water use for tomato processing ranges from 545 to 7,079 liters per ton of tomatoes (144 to 1,870 gallons per ton) 
(Mannapperuma 1993). Water use for peach processing ranges from 6,800 to 15,000 liters per ton of peaches (1,800 to 3,900 gallons per ton of peaches) (Mannapperuma 1993).

In the dairy sector, the average wastewater flow rate for a facility that produces cheddar curd, electrodialyzed whey, and dried condensed milk, and has been pretreated by filter and clarification is 1.34 million liters per day (353,000 gallons per day) (Bough W. and R. Carawan 1996). A dairy facility that produces yogurt, sour cream, and whipping cream, and has been treated with flow equalization will have an average flowrate of 746,000 liters per day (197,000 gallons per day) (Bough W. and R. Carawan 1996). Cheddar and dried whey production that is pretreated with trickling filters and clarification will produce an average flowrate of 772,000 liters per day (204,000 gallons per day) (Bough W. and R. Carawan 1996). Table 15 shows the annual wastewater discharge for a Midwest dairy facility.

Table 15. Annual Wastewater Discharge

\begin{tabular}{|c|c|}
\hline Facility & $\begin{array}{c}\text { Million liters per year } \\
\text { (Million gallons per year) }\end{array}$ \\
\hline $\begin{array}{c}\text { Cheddar curd, electrodialyzed whey, dried } \\
\text { condensed milk }\end{array}$ & $416(110)$ \\
\hline Yogurt, sour cream, whipping cream & $204(54)$ \\
\hline Cottage cheese, dried cheese coatings & $235(62)$ \\
\hline Cheddar, dried whey & $310(82)$ \\
\hline
\end{tabular}

Source: Bough W. and R. Carawan. "Wastewater Pretreatment in Dairy Plants: Does it Save Money?" Water Quality and Waste Management. 1996.

In 1999, food processing facilities in California had a coincident peak load of 0.3 GW (Brown R. and J. Koomey 2003). Summer and winter load profiles for a fruit processing wastewater treatment facility are shown in Figures 1 and 2. Note that the weekend days $(7 / 12,7 / 13,1 / 12$, and $1 / 13)$ show a significantly lower load than days when the facility is operating at full capacity. 


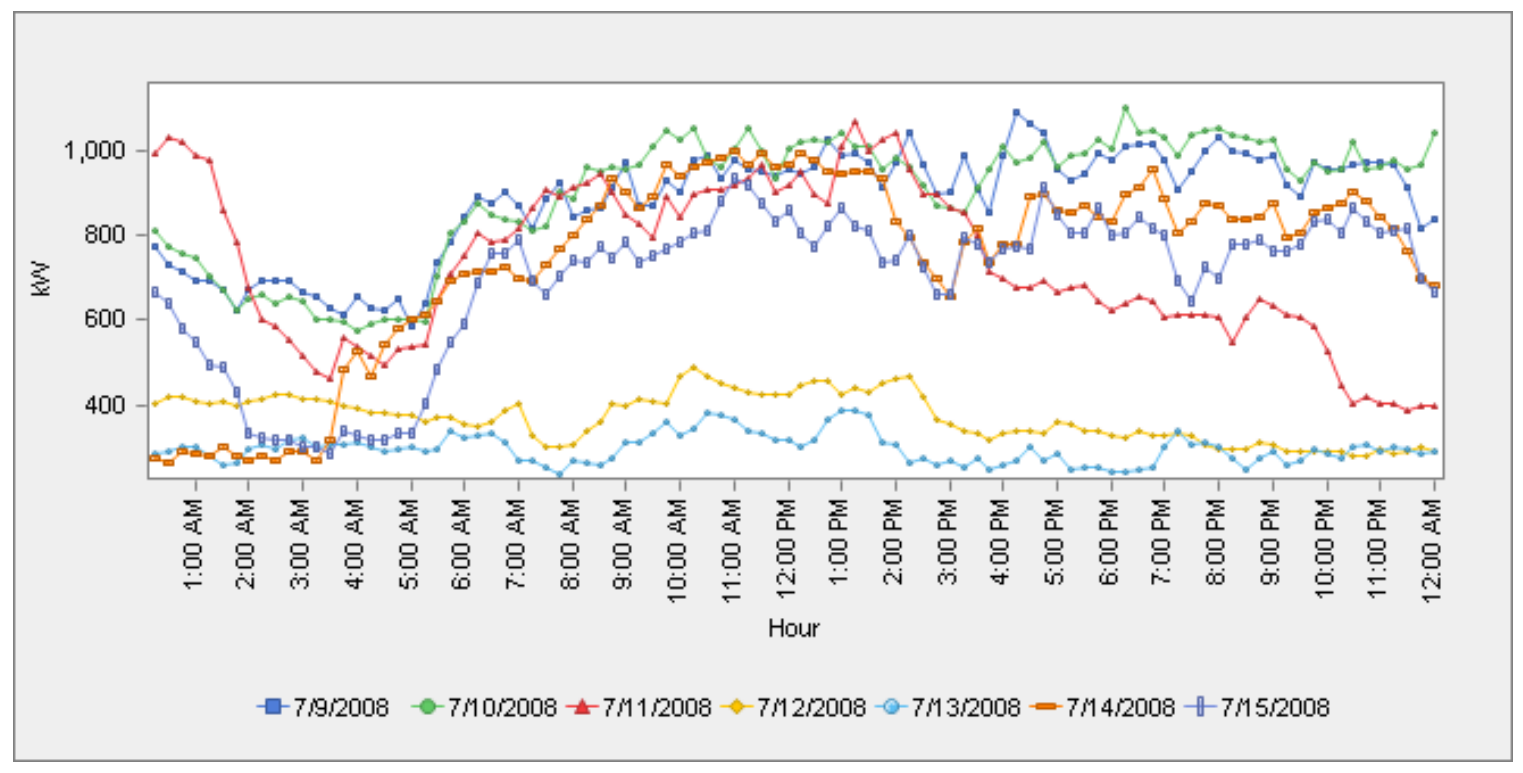

Figure 1. Food Processing Wastewater Treatment Facility - Summer

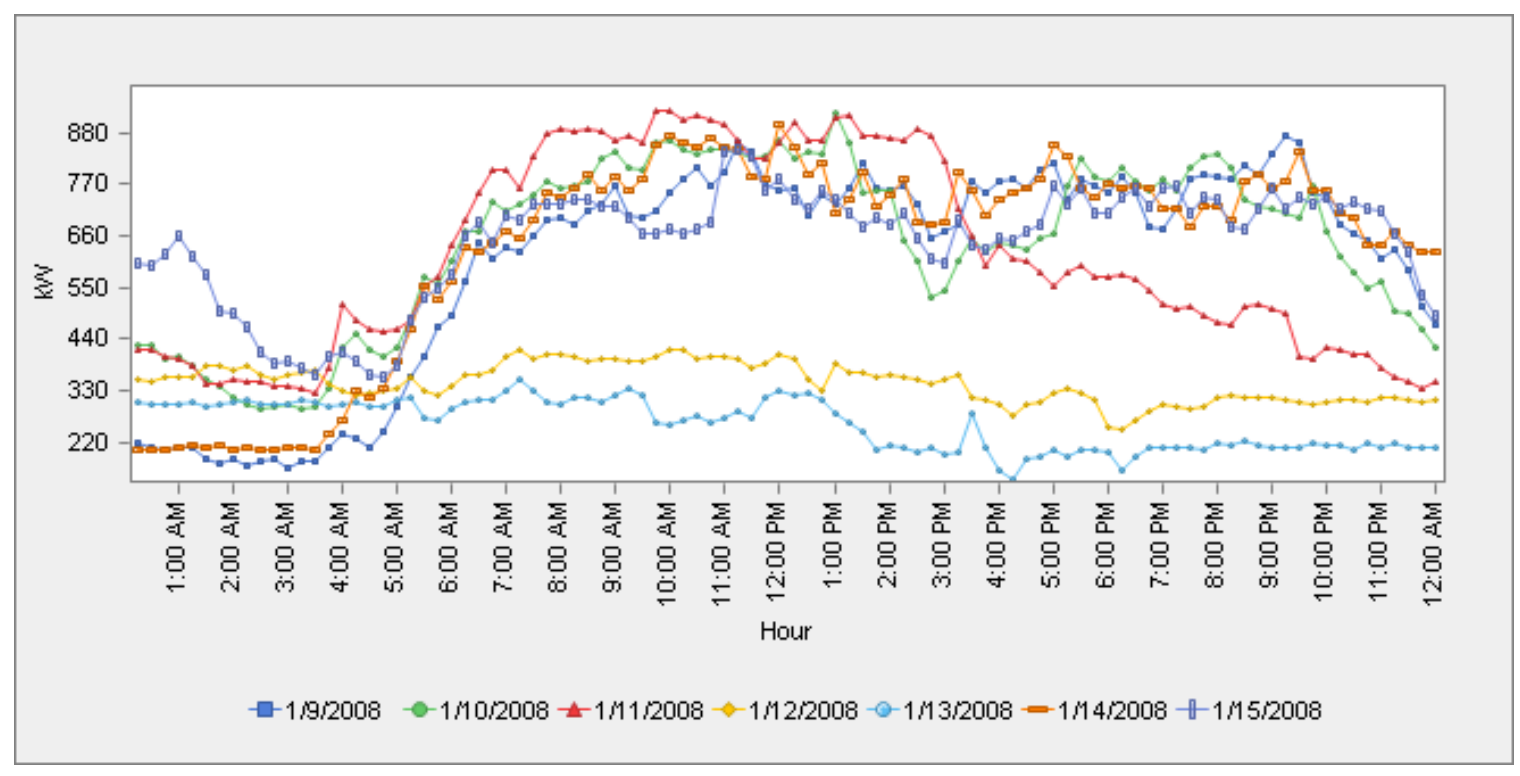

Figure 2. Food Processing Wastewater Treatment Facility - Winter

\subsubsection{Energy Use in the Petroleum Refining Industry}

In 1997, California's petroleum refining industry consumed 7,266 million $\mathrm{kWh}$ of electricity (California Energy Commission 2008). The amount of wastewater generated in a refinery depends on several factors such as crude capacity, number of refining processes, crude source, and operating procedures (Wang 2005).

Petroleum refineries use roughly one barrel of water to process one barrel of oil. Between cooling water, utility water, boiler feed water, and other uses, more than 10.6 billion liters ( 2.8 billion gallons) of water are used at petroleum refineries every day 
(Schultz 2008). Additionally, the average petroleum refinery generates about 0.6 barrels of wastewater per barrel of oil processed, which equates to 6.4 billion liters of wastewater per day (1.7 billion gallons) that must be treated to meet environmental discharge or reuse standards (Schultz 2008).

\subsubsection{Energy Use in the Electronics Industry}

Electronics manufacturing is a very resource intensive process. Manufacturing silicon wafers requires large water volumes (Byron 2005) and the electronics and computer industry annual electricity use is 38,000 million $\mathrm{kWh}$ with the semiconductor subsector using 13,000 million kWh annually (Energy Information Administration 2002). Most of the energy in the semiconductor industry is used in air handling, equipment production, and deionized and Ultra Pure water production, which is used to rinse and clean semiconductors (Pacific Northwest Pollution Prevention Resource Center 2000). About $20 \%$ of this energy is associated with pumps used throughout the production process (Pacific Northwest Pollution Prevention Resource Center 2008). Water is also used throughout electronics manufacturing processes to remove unwanted residues during the production process (Byron 2005).

Electronics manufacturers are working to restrict wastewater discharge volume through water efficiency, reclaiming and recycling wastewater, or subsidizing the expansion of municipal treatment capacity (Pacific Northwest Pollution Prevention Resource Center 2008). Further, a survey of electronics manufacturing services, providers, and manufacturers shows a growing movement toward Restriction of Hazardous Substances compliance, which puts restrictions on the use of hazardous substances in electronic equipment (Carbone 2008).

Further, zero liquid discharge has been a goal for water conservation in the semiconductor industry. Zero liquid discharge is the total elimination of liquid waste discharge, which is done through recycling the wastewater to reduce energy and material input into the cleaning process (Byron 2005). Water that is considered too polluted to clean can be used in cooling towers and scrubbers. While semiconductor manufacturing is a relatively minor user of the total water supply, its impact on water energy use in specific regions (e.g., California's Silicon Valley) can be significant.

\subsubsection{Energy Use in the Cement Manufacturing Industry}

Cement manufacturing is one of the most energy intensive industrial manufacturing processes (Wilson 1993). California is the largest cement producing state in the United States, having 31 cement manufacturing industries that consume 1,600 GWh of electricity, 22 million therms of natural gas, and 2.3 million tons of coal annually (Coito 2000). The main energy-intensive process in cement manufacturing is operating rotary cement kilns, and dry-process kilns use up to $50 \%$ less energy than wet-process kilns (Wilson 1993).

About $600 \mathrm{~kg}$ of water is used to manufacture one tonne of cement in a wet-process plant (Environmental Agency 2005). However, a shift from wet-process plants to dryprocess plants has greatly reduced the cement industry's need for water (Noding 2007). Reuse and recycling of cement process wastewater can greatly reduce energy needed for wastewater treatment. Stormwater systems and storage areas can help to minimize 
effluent discharge by reducing wash-off of solids and recycling cooling waters. In addition, cooling towers, settling ponds, containment ponds, and clarifiers aid in recycling and reusing effluent water (Egyptian Environmental Affairs Agency 2005). Cement manufacturers can also use sludge and wastewater generated outside wastewater treatment plants to make their cement (Meeroff 1999; Egyptian Environmental Affairs Agency 2005). Newer cement plants have greatly reduced water use and many more are seeking to have closed-loop water recycling systems (Wilson 1993).

\subsubsection{Energy Use in Municipal Wastewater Treatment Facilities}

Municipal wastewater flowrates vary depending on the time of day, day of the week, season of the year, or sometimes on the nature of the discharge. Wastewater flows at municipal treatment facilities often follow a diurnal pattern where the peak flows generally occur twice a day: once in the late morning when wastewater from the peak morning water use reaches the wastewater treatment facility and a second peak flow during the early evening between 7 and 9 p.m. (Tchobanoglous 2002). Figures 3 and 4 show sample load patterns in municipal wastewater treatment facilities during the summer and winter.

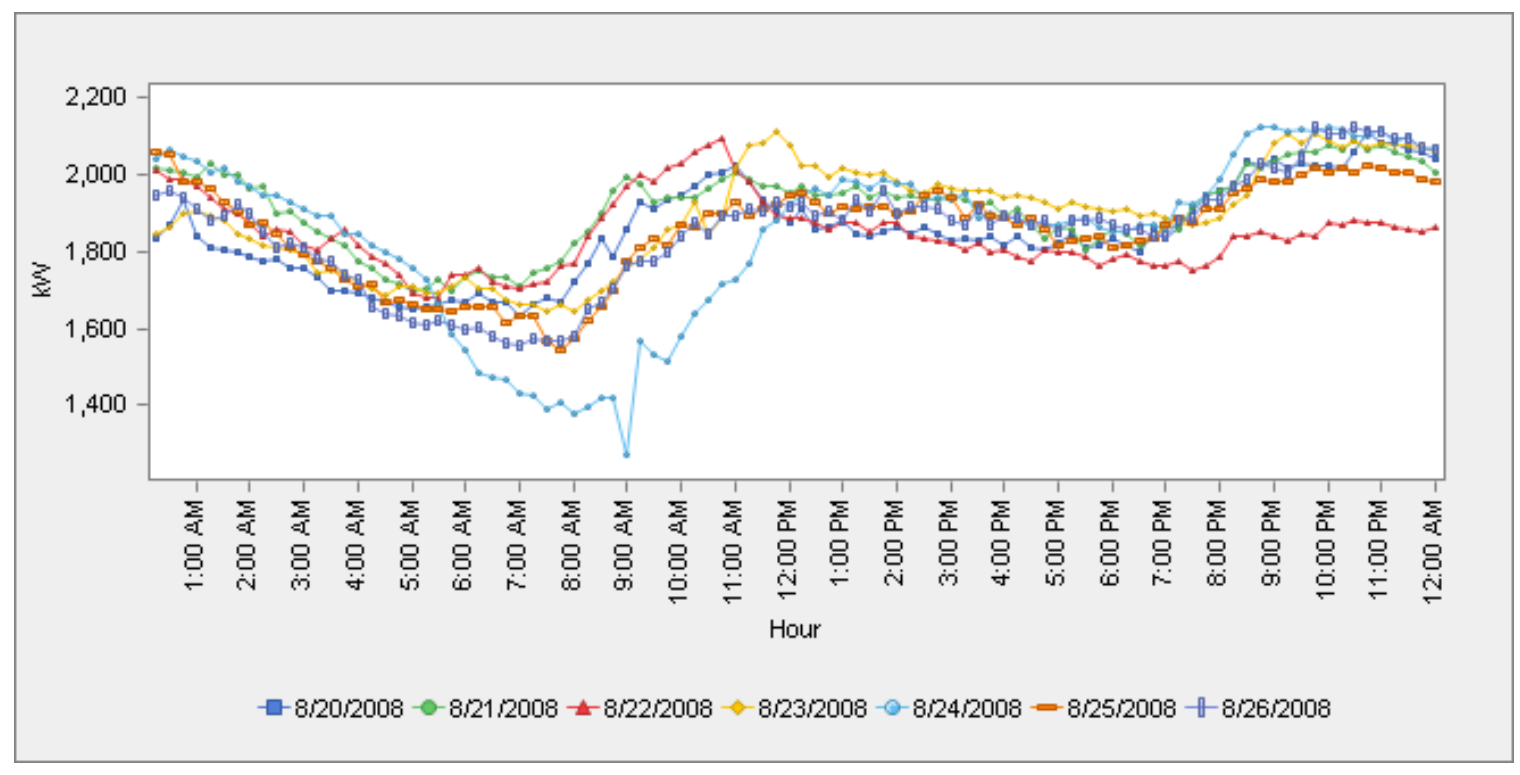

Figure 3. Municipal Wastewater Treatment Facility Load Pattern - Summer 


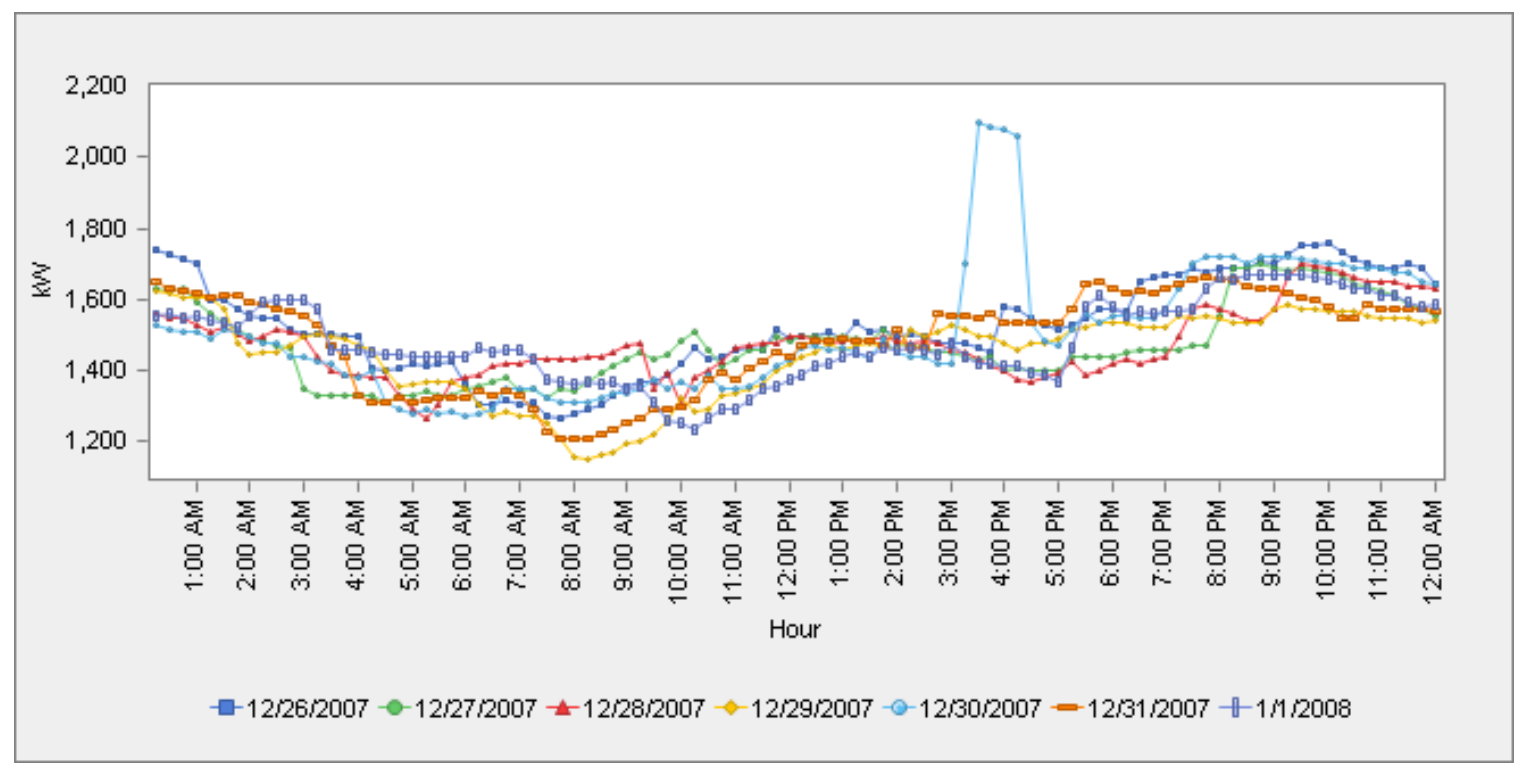

Figure 4. Municipal Wastewater Treatment Facility Load Pattern - Winter

This research finds that, in general, the electronics and cement manufacturing industries are introducing processes that are greatly reducing water use and wastewater generation, such as using $\mathrm{SO}_{3}$ in the semiconductor cleaning processes and the dry processing of cement. This indicates that while the energy use in wastewater treatment in these industries is significant, it is decreasing. Further, according to the EPA, there are 1,716 wastewater treatment facilities which have received NPDES permits for discharging wastewater. Of these, 373 , or $22 \%$, are categorized as food processing facilities and 336 , or $20 \%$ are categorized as municipal wastewater treatment facilities. Only $1 \%$ of sites are categorized as either electronics, cement, or petroleum refining (Environmental Protection Agency 2009). In addition to the large number of food processing and municipal wastewater treatment facilities, this research finds that within the food processing industry and municipal wastewater treatment facilities, there is no indication of significant water or energy saving measures being introduced. The remainder of this report focuses on the energy efficiency and OpenADR potential for wastewater treatment in municipalities and the food processing industry. The importance of these two key sectors to California, combined with the growing energy use of wastewater treatment facilities and the lack of reported significant reduction of water use, make these two sectors particularly important candidates for energy efficiency and OpenADR measures. 


\subsection{Wastewater Treatment Processes}

The wastewater treatment process and its energy use assessment are essential to identify potential for implementation of OpenADR and energy saving measures. This section provides details of the wastewater treatment process for both municipal wastewater treatment facilities and food processing wastewater treatment facilities. While the basic structure of the wastewater treatment process is similar for both the municipal and food processing wastewater treatment facilities, there are important differences in how wastewater is treated. These differences will be addressed along with the basic wastewater treatment process for each industry. This section also focuses on specific equipment and its energy use in the wastewater treatment process.

\subsection{General Wastewater Treatment Process}

Wastewater treatment processes can be broken down into four major components: preliminary, primary, secondary, and tertiary treatment followed by disinfection and discharge into a river or stream. Preliminary treatment involves the removal of coarse solids that may interrupt treatment operations. Primary treatment removes suspended solids and organic matter and is characterized by screening and sedimentation.

Secondary treatment is the removal of the remaining soluble and organic material using microorganisms. Tertiary, or advanced, treatment is the extended level of treatment to remove nutrients, toxic compounds, and other organic material and suspended solids that are still left in the wastewater after secondary treatment (Wilkinson 2000). Depending on the industry, wastewater treatment may not include tertiary treatment; however, disinfection is usually the last major step in all industries before the wastewater effluent is discharged back into a lake, river, or stream.

These treatment processes can also be categorized under three types of operations: physical, chemical, and biological (Wilkinson 2000). Each type generally refers to a certain point in the wastewater treatment process. Primary treatment removes solids physically, while secondary treatment uses biological operations. Tertiary treatment processes wastewater chemically.

\subsection{Municipal Wastewater Treatment Process}

Municipal wastewater treatment facilities typically treat residential and commercial wastewater. However, municipal wastewater treatment facilities often additionally process industrial wastewater, which also needs to be treated to meet federal and local regulations. Figure 5 shows the basic steps of the municipal wastewater treatment process. Below each stage of the treatment process for municipalities is described. 


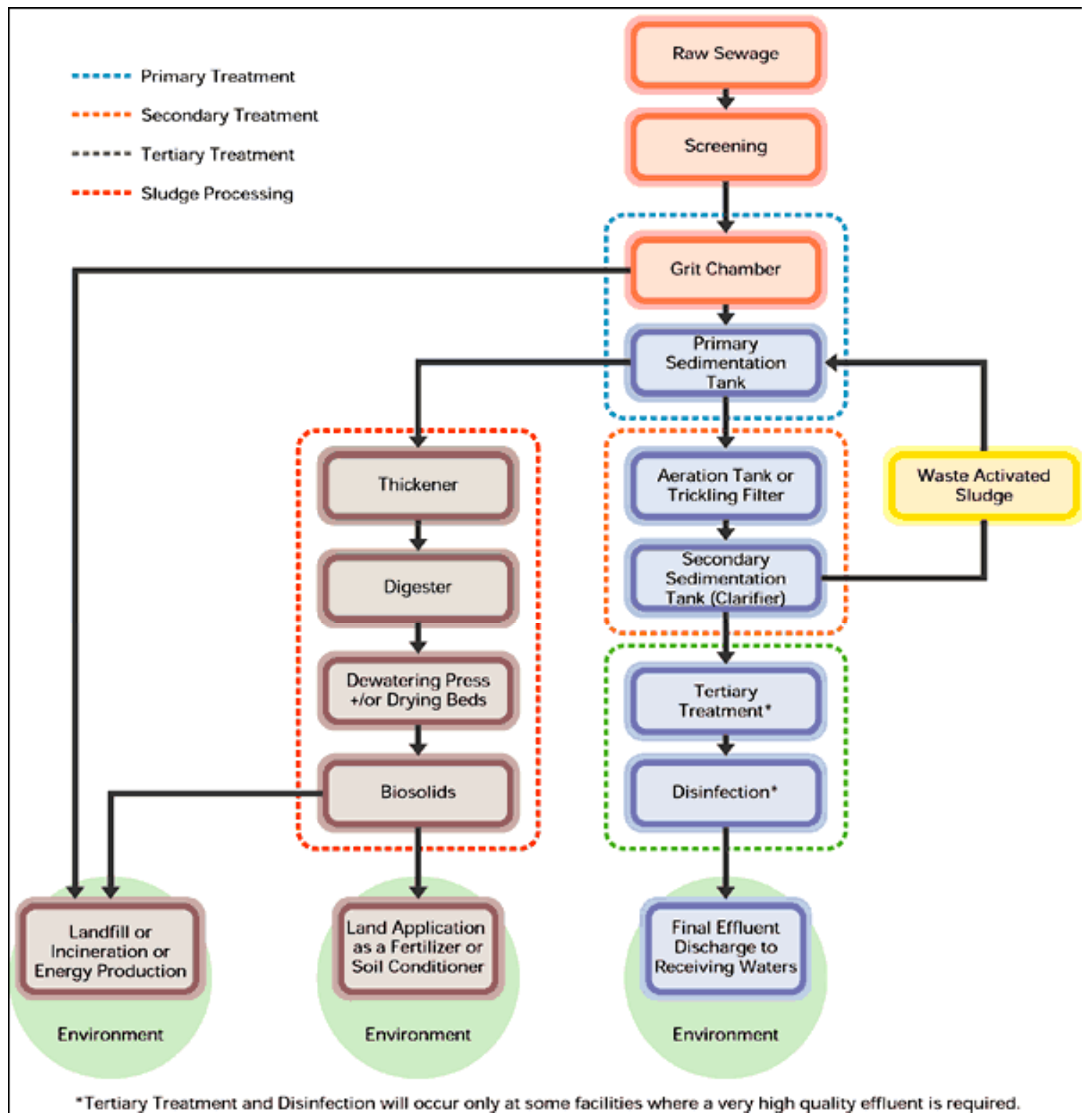

\section{Figure 5. Municipal Wastewater Treatment Process}

Source: United Nations Environment Programme. "Wastewater Treatment: The Municipal Sludge Production Process."

Preliminary Treatment: Wastewater is delivered to the treatment facility through a series of pipes and pump systems. It then is run through a series of screens to remove coarse materials such as paper, rocks, plastic, and rags (East Bay Municipal Utility District). Screenings, which are the material left on the screens, are removed directly into a screenings grinder, a pneumatic ejector, or a container for disposal (Metcalf \& Eddy Inc. 2003). An alternative for bar screens or fine screens is a grinder that can shred coarse solids, which can then later be removed from the wastewater (Metcalf \& Eddy Inc. 2003). Comminutors, macerators, and grinders are the equipment which handle coarse solids that are not removed from the wastewater. The coarse solid objects are ground to a size 
that is small enough to pass through the screens, and then the water is lifted with a pump into a grit chamber (William Nazaroff and Lisa Alvarez-Cohen 2004).

Grit is removed by the centrifugal separation of solids. Grit chambers are commonly located after the bar screens and before the primary sedimentation tanks in a wastewater treatment facility (Metcalf \& Eddy Inc. 2003). In aerated grit chambers, air is added alongside the tank. The velocity of roll or agitation determines the size of particles that can be removed (Metcalf \& Eddy Inc. 2003). Large solids such as gravel and coarse sand can be removed completely with proper adjustment (Metcalf \& Eddy Inc. 2003). Also, grit pumps in grit chambers can operate continuously or run on cycles based on time or flow (Metcalf \& Eddy Inc. 2003). In order to operate the aerated grit chambers efficiently, the amount of air produced should be matched with the flow. Too little air will result in odorous material that will be difficult to dispose and too much air will result in little grit being removed (Energy Conservation Task Force of the Water Environment Federation 1997).

Primary Treatment: The remaining settleable and flotable materials are removed during primary sedimentation (William Nazaroff and Lisa Alvarez-Cohen 2004). Primary sludge is pumped from the clarifiers and sent to digesters for additional treatment (East Bay Municipal Utility District). Wastewater flows are also equalized during primary treatment. Flow equalization is a method used to limit flowrate variations in order to improve the performance of downstream processes (Metcalf \& Eddy Inc. 2003). The location of a equalization basin depends on the characteristics of the collection system, the type of wastewater, land requirements and availability, and type of treatment necessary (Metcalf \& Eddy Inc. 2003). Equalization after primary treatment is appropriate because it reduces problems with solids deposits in the secondary treatment (Metcalf \& Eddy Inc. 2003).

Secondary Treatment: In the secondary treatment process, the effluent goes through secondary treatment, where microorganisms break down organic material, such as sugars, fats, and proteins, that were not removed in the primary sedimentation process (East Bay Municipal Utility District). This process reduces the majority of $\mathrm{BOD}_{5}$ and suspended solids present in the wastewater (William Nazaroff and Lisa Alvarez-Cohen 2004). Oxygen is supplied so that microorganisms can complete this process (East Bay Municipal Utility District). After this step, only low levels of $\mathrm{BOD}_{5}$ and particulate matters remain in the wastewater; however, there might still be high concentrations of nutrients and organics (William Nazaroff and Lisa Alvarez-Cohen 2004).

There are three main types of secondary treatment options that are administered by wastewater treatment facilities: activated sludge process, trickling filters, and lagoons. In the activated sludge process, the sludge provides nutrients for microorganisms that breakdown organic material during aeration and agitation. The activated sludge and wastewater flows to a secondary clarifier and the activated sludge settles out. Some of the activated sludge is recycled back into the aeration basin to maintain an environment for organic decomposition (Metcalf \& Eddy Inc. 2003). A trickling filter system is a type of fixed film treatment method made up of small rocks, gravel, and other material. The surface contains a microbial layer that oxidizes and nitrifies any organic material (Metcalf \& Eddy Inc. 2003). Similar to activated sludge and trickling filter methods of 
treatment, lagoon systems require aeration for the breakdown of organic matter (Maine Lagoon Systems 2003).

Tertiary Treatment: A tertiary stage, or advanced treatment stage, may include biological treatment for nitrogen or phosphorus removal, chemical precipitation for phosphorus or metals removal, single or multimedia filters that may contain activated carbon for additional solids and refractory organics removal, and air stripping for ammonia removal (William Nazaroff and Lisa Alvarez-Cohen 2004).

Disinfection: The resulting wastewater from the previous process is disinfected to remove the remaining pathogens and bacteria. Energy intensive technologies are used to ensure compliance and control costs so that wastewater treatment facilities can meet stringent drinking water regulations (Means 2004). These new technologies include the use of microfiltration, ultrafiltration, nanofiltration, and reverse osmosis membranes, as well as ozone and ultraviolet light disinfection/ oxidation technologies (Means 2004). If chlorine is used in the disinfection process, dechlorination will be necessary to remove chlorine before the wastewater is released (William Nazaroff and Lisa Alvarez-Cohen 2004). Some wastewater facilities disinfect with on-site generated sodium hypochlorite solution. This has advantages over conventional chlorination disinfection treatments in that chlorine gas cylinders are not required and water use is reduced (California Office of the Governor 2001; Siemens Water Technologies 2007). Chloramine solution is pumped from ammonia and sodium hypochlorite storage tanks for treatment on a need basis (California Office of the Governor 2001). After disinfection, the treated water is released into the environment.

\subsection{Food Processing Wastewater Treatment Process}

Many food processing facilities discharge their wastewater to a municipal wastewater treatment facility, but are required to pretreat their wastewater in order to prevent equipment difficulties and treatment issues at the municipal wastewater treatment facilities (Barnes 1984). Depending on local regulations concerning indirect discharges and wastewater characteristics from a particular food processing plant, food processing wastewater treatment facilities may or may not administer secondary or tertiary treatment. However, facilities which discharge their wastewater directly into a river or stream will typically perform all major steps of the treatment process. The general treatment process for the food processing industry is described below, followed by the treatment methods specific to three major food processing subsectors, fruit and vegetable processing, meat and poultry processing, and dairy processing.

Preliminary Treatment: Pretreatment usually consists of gross solids removal, silt removal, and screening of coarse or large solids and any other particles that might upset municipal wastewater treatment facilities (Barnes 1984). First, the food processing wastewater is screened, where coarse solids that might interfere with normal sewer flow or further treatment are removed (Barnes 1984). Settling ponds or lagoons, also known as silt ponds, are often used for silt removal (Barnes 1984). Neutralization is an important step in the pretreatment process to protect sewerlines and to prevent $\mathrm{pH}$ shocks to the municipal wastewater treatment facilities (Barnes 1984). A neutralization system usually includes mixing tanks, chemical storage areas and equipment, and $\mathrm{pH}$ 
monitoring and recording equipment (Barnes 1984). Oil and grease removal is achieved using a grease trap, which is similar to a septic tank and removes floating oil and grease through the use of baffles. A gravity clarifier is used to remove large quantities of oil and grease. Wastewater flow is also equalized during preliminary treatment. Flow equalization smoothes-out flow variations, and manages surges that may arise from accidental spills or facility cleanup (Barnes 1984).

Primary: A gravity clarifier or settling tank is used for solids separation and thickening. A flotation clarifier utilizes both gravity separation and fine bubble aeration to float solids that do not settle by gravity. Although this equipment is able to remove both settleable and non-settleable solids, it requires high amounts of energy and mechanical maintenance. Anaerobic treatment requires less electrical energy because oxygen is not required. It may be used to treat wastewater as an intermediate step prior to further aerobic treatment and to meet pretreatment standards (Barnes 1984).

Secondary: The main objective of secondary treatment is to provide an environment suitable for growth of biological organisms. If the environment is inadequate for the proper growth of bacteria and other micro-organisms, it can result in system failure (Barnes 1984). Neglecting a sufficient supply of oxygen can result in septic sludge and unwanted micro-organisms may proliferate and cause solids buildup within the treatment system and result in poor effluent quality (Barnes 1984). Treatment processes that will generate safe effluent quality at the lowest operating costs depend on individual site restrictions, waste characteristics, local power costs, effluent requirements, and other factors (Barnes 1984). Non-aerated ponds and lagoons do not have mechanical aeration and oxygen is supplied by biological means (Barnes 1984).

Trickling filters are one of the oldest aerobic biological treatment systems and produce relatively stable effluent under varying waste discharge conditions. However, there is less process flexibility using trickling filters, which also have high capital costs. The activated sludge process has replaced the use of trickling filters over the years. A major advantage of the activated sludge process is the facility operator's ability to control the system under a variety of load conditions. The operator can modify conditions to reduce power requirements and sludge production. Rotation biological contactors are devices that rotate on a horizontal shaft to allow contact between bacteria and raw wastewater. The rotating disk allows for mixing and oxygen transfer (Barnes 1984).

Tertiary Treatment: Tertiary treatment includes processes such as nitrification, chemical precipitation, sedimentation, filtration, carbon adsorption, ion exchange, reverse osmosis, and ammonia stripping. Nitrification is conducted in the aeration basin, biofilter or other $\mathrm{BOD}_{5}$ removal device used in a secondary wastewater treatment facility (Barnes 1984). It requires specific environmental conditions and parameters in order for the nitrate form of nitrogen to be achieved. Chemical precipitation and sedimentation allows for the formation of a precipitate that will be dense enough to settle out by gravity. Filtration reduces solids content, $\mathrm{BOD}_{5}$, nitrogen, and other compounds that may have not been removed in the secondary treatment step (Barnes 1984). Adsorption is a process where a constituent in the liquid phase is transferred to the solid phase (Metcalf \& Eddy Inc. 2003). The process of adsorption on activated carbon has been increasingly utilized in wastewater treatment in response to demands for a higher 
quality of treated wastewater effluent and toxicity reduction (Metcalf \& Eddy Inc. 2003). Ion exchange is used in wastewater treatment for the removal of nitrogen, heavy metals, and total dissolved solids through the displacement of ions (Metcalf \& Eddy Inc. 2003). Reverse osmosis occurs when water moves across a membrane from a lower concentration to higher concentration. It is used as filtration and helps to purify the water. Ammonia stripping is used to remove ammonia, carbon dioxide, oxygen, hydrogen sulfide, and volatile organic compounds. Figure 6 shows the basic steps in the wastewater treatment process for food processing.

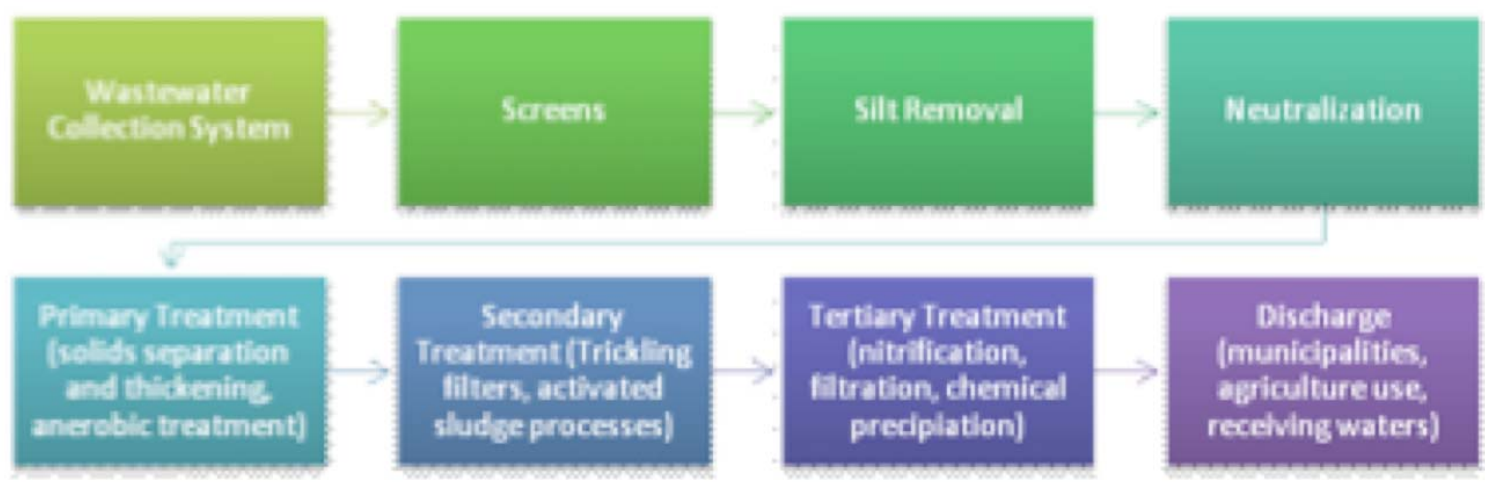

Figure 6. Food Processing Wastewater Treatment Process

\subsubsection{Food Processing - Fruit and Vegetable}

The only pretreatment steps required for many fruit and vegetable processors are the primary and secondary treatment processes (Barnes 1984). Tertiary treatment is not necessary for this sector due to lower levels of toxic chemicals in the food processed wastewater, however, tertiary treatment sometime may be required to comply with discharge regulations, in which case nitrification, filtration, chemical precipitation, and sedimentation may be used to treat food processing wastewater (Barnes 1984). Large amounts of soil and silt that result from washing and handling raw fruit and vegetable products must be removed before the water reaches municipal wastewater treatment facilities (Barnes 1984). Gravity clarifiers used in the treatment of fruit and vegetable waste are equipped with oil and grease skimmers.

\subsubsection{Food Processing - Meat and Poultry}

The waste stream from meat and poultry processing facilities is more difficult to treat than the wastewater from fruit and vegetable processing due to higher pollutant concentrations. Meat and poultry processors are required to remove the majority of soluble and particulate organic material in their wastewater prior to discharge in order to achieve compliance with local, state, and federal environmental regulations (Lyco Manufacturing 2007). 
One issue in particular is the large amount of fats and blood that is present in meat and poultry wastewater. Fats and other large particulates often clog the screen openings and interrupt the treatment process. One way of eliminating this problem is by using selfcleaning screens. Another way to facilities can manage high levels of solids in waste streams is to use rotary or drum screens (Barnes 1984). Settleable solids, fats, oils, and grease are removed by gravity clarification. Clarifiers are tanks that allow settleable solids to reach the bottom of the tank and floatable fats, organics, and grease to reach the top (Barnes 1984). Air flotation is applied to meat, poultry, and rendering wastewaters so that particles can be separated according to their density (Barnes 1984).

Anaerobic processes consist of a basin that receives the wastewater at a high organic loading rate and provides aeration to the wastewater. Anaerobic processes utilize anaerobic or facultative bacteria to degrade organic wastes at high temperatures. The anaerobic lagoon is a common application of anaerobic processes to meat, poultry, and rendering wastewater treatment (Barnes 1984).

Trickling filters are not well suited to the treatment of high-strength organic wastes from meat and poultry facilities. Plastic filter media have been developed to handle higherstrength organic wastes. Rotating biological contactors also remove organic wastes. This process is capable of achieving effluent quality comparable to that of activated sludge treatment but at approximately half of the energy demand (Barnes 1984). Disinfection is a necessary step for meat and poultry processing since wastewater from meat and poultry operations may contain significant numbers of various pathogenic microorganisms.

\subsubsection{Food Processing - Dairy}

High amounts of dairy waste are detrimental to aquatic life and must be treated before dairy processing wastewater can be released back into the environment. Dairy processing facility wastewater includes milk or milk products, detergents, sanitizers, lubricants, and chemicals from boiler and water treatment (Barnes 1984). Dairy processing wastewater is characterized by relatively high organic concentration and high initial total oxygen demand (Barnes 1984). About 95\% of U.S. dairy facilities discharge their wastewater to municipal treatment facilities (Barnes 1984). Frequently, the only pretreatment required of dairy food processing facilities is the removal of floating fat and suspended solids. This can help to reduce the waste load that enters the municipal treatment facilities, where treatment is finalized before the wastewater is returned to the environment (Barnes 1984).

\subsubsection{Equipment Energy Use}

Understanding energy use in wastewater treatment process equipment can help determine the potential areas for energy conservation and implementation of OpenADR strategies. Focusing energy efficiency and OpenADR strategies on highly energyintensive equipment will produce the greatest energy and demand savings. Aeration and pumping systems are often large energy users, however, other equipment also use a significant portion of electricity.

In many wastewater treatment facilities, the main equipment end users of electricity are aeration, wastewater pumping, dissolved air flotation, anaerobic digestion, trickling 
filters, and lighting (Energy Conservation Task Force of the Water Environment Federation 1997). This section will discuss the equipment energy use in the wastewater treatment process.

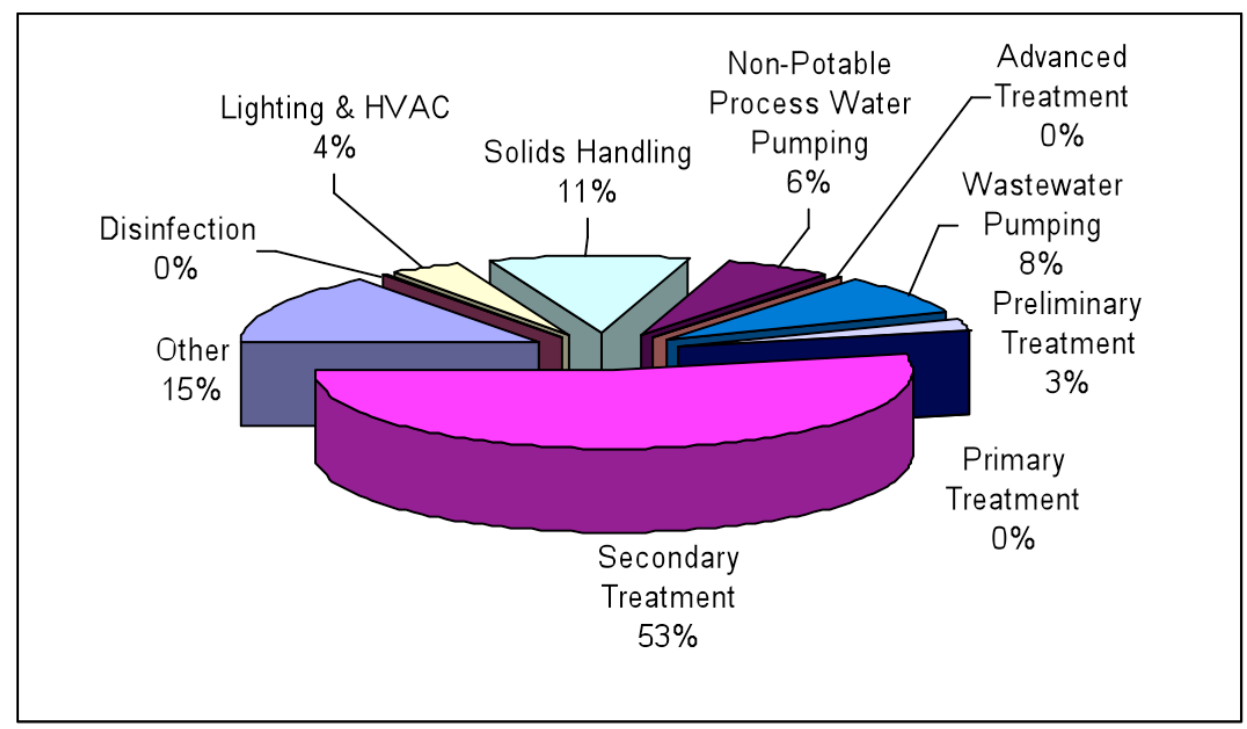

Figure 7. Municipal Wastewater Treatment Equipment Energy Use

Source: Kleyman, J. (2006). Municipal Wastewater Treatment Plant Energy Evaluation. Municipal Wastewater Treatment Plant Energy Evaluation. Buffalo, NYSERDA.

Wastewater pumping: The energy required for influent wastewater pumping can range from $15-70 \%$ of the total electrical energy depending on the wastewater treatment facility site elevation and influent sewer elevation. The facilities shown in Figure 7 are represented in the lower end of this range. If the energy required to operate all of the pumps in the collection system is considered, including effluent pumping and pumping within the facility, total pumping energy requirements may represent as much as $90 \%$ of the total energy used (Energy Conservation Task Force of the Water Environment Federation 1997).

Grit removal: Typically, grit removal does not consume much energy. However, in aerated grit chambers, as opposed to velocity-type grit basins, blowers consume a considerable amount of energy. Reducing the air produced by these blowers can reduce facility energy use (Energy Conservation Task Force of the Water Environment Federation 1997).

Primary clarifiers: Inefficient operation of primary clarifiers can lead to high TSS and $\mathrm{BOD}_{5}$ loadings. By retrofitting the primary clarifiers, $\mathrm{BOD}_{5}$ removal will be improved, increasing oxygenation capacity and reducing energy use (Water Environment Federation 2007).

Trickling filters: Trickling filters are used in treating both municipal and industrial wastewater. Trickling filters require energy for influent pumping and circulation 
(Metcalf \& Eddy Inc. 2003). The filter is a porous seal that covers a rock or plastic packing. The wastewater trickles downward through the packing to the underdrain where the effluent liquid is collected and is passed to a sedimentation tank where the effluent separated (Metcalf \& Eddy Inc. 2003).

Anaerobic digestion: Anaerobic digesters break down the volatile fraction of the sludge so the non-volatile solids can be disposed of in landfills or used as fertilizers (Global Energy Partners LLC 2007). During anaerobic digestion, anaerobic selectors are used to stress the organisms before they are released back into an oxidative environment. This causes the organisms to take up more phosphorous than they need and they store the excess phosphorus within their cells (Energy Conservation Task Force of the Water Environment Federation 1997). A byproduct of this process is biogas which contains 5070\% methane, 30-45\% carbon dioxide, and water vapor (Global Energy Partners LLC 2007). This biogas can be used to generate heat and electricity (The California Energy Commission 2008).

Aeration: Aeration systems consist of blowers and diffusers, which generate and inject air into reactor tanks (Wells 2004) to allow for microbial degradation of organic matter (Environmental Protection Agency 1999). Aeration devices such as aerator blowers are the most significant consumers of energy in a wastewater treatment system (Energy Conservation Task Force of the Water Environment Federation 1997). A typical wastewater treatment facility with a diffused aeration system uses 50-90\% of its electric power to run blower motors (Jenkins 1996). Installing variable-speed drives for blowers and matching the blower output with air requirements can reduce energy use. Aeration systems help wastewater treatment facilities meet effluent ammonia nitrogen levels, since oxygen demand greatly increases during nitrification. Other important factors for meeting aeration requirements include maintaining the solids retention time, as well as monitoring the effect of temperature, DO levels, and $\mathrm{pH}$ on nitrification (Bolles). Common types of mechanical surface aeration equipment are low-speed mechanical aerators, direct drive surface aerators, and brush-type surface aerators (Bolles). Diffused aeration systems consist of a low pressure, high volume air compressor (blower), air piping system, and diffusers (Bolles). Some aeration systems combine diffusers with mechanical aerators. Aeration equipment also helps provide adequate mixing in the tanks to prevent solids from settling. The size and number of aerators in the wastewater treatment system is determined by the $\mathrm{BOD}_{5}$ of the wastewater and by the aerator efficiency. Check valves help to prevent reverse of airflow when the blower is not in operation or when the equipment is warming up (Metcalf \& Eddy Inc. 2003). Fine bubble diffusers coupled with variable flow compressors and energy efficient motors can reduce aeration energy consumption by 50\% (Wells 2004).

Pumping: Return activated sludge pumping is also required for the activated-sludge process. Return activated sludge rates are usually expressed as a percentage of the influent flow and typically range between $40-100 \%$ of the influent flow. Return activated sludge pumps require almost as much energy per unit as influent pumps but usually have slightly lower total dynamic head and energy requirements (Energy Conservation Task Force of the Water Environment Federation 1997). 
Dewatering: An activated sludge wastewater treatment facility typically uses $7 \%$ of its total energy for solids dewatering (Efficiency Vermont). A high amount of energy is required in breaking down the bond strength of the sludge moisture content (Chu 2005). Dewatering commonly involves the use of equipment with varying energy-intensities, including centrifuges, belt-filter presses, recessed-plate filter presses, drying beds, and lagoons (Metcalf \& Eddy Inc. 2003). Therefore choosing the most efficient dewatering method for the particular wastewater treatment facility is important in reducing energy consumption.

Table 16 summarizes the type of equipment used in wastewater treatment facilities.

Table 16. Equipment Commonly Used in Wastewater Treatment Facilities

\begin{tabular}{|c|c|}
\hline Process or operation & Commonly used equipment \\
\hline $\begin{array}{l}\text { Pumping and preliminary } \\
\text { treatment }\end{array}$ & $\begin{array}{c}\text { Chemical feeders for prechlorination, influent pumps, } \\
\text { screens, screenings press, grinders and macerators, } \\
\text { blowers for preaeration and aerated grit chambers, } \\
\text { grit collectors, grit pumps, air lift pumps }\end{array}$ \\
\hline Primary treatment & $\begin{array}{l}\text { Flocculators, clarifier drives, sludge and scum } \\
\text { pumps, blowers for channel aeration }\end{array}$ \\
\hline Secondary treatment & $\begin{array}{c}\text { Blowers for channel and activated-sludge aeration, } \\
\text { mechanical aerators, trickling filter pumps, trickling } \\
\text { filter distributors, clarifier drives, return and waste } \\
\text { activated-sludge pumps }\end{array}$ \\
\hline Disinfection & $\begin{array}{c}\text { Chemical feeders, evaporators, exhaust fans, } \\
\text { neutralization facilities, mixers, injector water pumps, } \\
\text { ultraviolet (UV) lamps }\end{array}$ \\
\hline Advanced wastewater treatment & $\begin{array}{l}\text { Blowers for nitrification aeration, mechanical } \\
\text { aerators, mixers, trickling filter pumps, pumps for } \\
\text { depth filters, blowers for air backwash, pumps for } \\
\text { membrane filtration }\end{array}$ \\
\hline Solids processing & $\begin{array}{c}\text { Pumps, grinders, thickener drives, chemical feeders, } \\
\text { mixers for anaerobic digesters and blending tanks, } \\
\text { aerators for aerobic digesters, centrifuges, belt } \\
\text { presses, heat dryer drives, incinerator drives, } \\
\text { conveyors }\end{array}$ \\
\hline
\end{tabular}

\subsection{Emerging Wastewater Treatment Technologies}

Several emerging wastewater treatment technologies may impact the energy use in these facilities, particularly the use of nanotechnology and electron beams (Jolley 2006). Solar nano-photocatalyts can disinfect microorganisms while removing organic compounds (Hinter 2005). Photocatalysts use energy from ultraviolet (UV) sunlight to remove microorganisms and break down undegradable compounds (Hinter 2005). This can help 
reduce energy use in the disinfection process and, unlike conventional chlorine disinfection, does not produce biologically non-degradable byproducts.

Nanostructured silica is another emerging nanotechnology that detects and eliminates toxic contaminants (Nanowerk Research 2007). The silica's large surface area and pores allow it to bind and extract heavy metals from wastewater. Nanotechnology research states that nano-based filters achieve $99.95 \%$ efficiency compared to conventional disinfection technologies (Frost and Sullivan 2006). However, the potential impacts of nanoparticles on aquatic organisms and ecosystems are still unknown and more research needs to be done before this method can be used by wastewater treatment facilities (Baier-Anderson 2008).

Many newer alternatives to the use of chlorine in wastewater disinfection rely on electricity and electron beams, which, although effective, are very energy intensive (Electric Power Research Institute 1999). Radiosensitizers, which are compounds that will enhance the disinfection by electron beam irradiation, lowers the beam intensity and could greatly reduce the energy use of electron beam disinfection (Electric Power Research Institute 1999).

Additionally, engineered wetlands can provide a unique alternative to wastewater treatment. Engineered wetlands use plants and bacteria to treat domestic wastewater. This option offers a low capital cost and operating cost savings, making it a viable option for smaller communities, especially where adequate space is available. Engineered wetlands can help to divert storm water from existing systems, and help to reduce energy used by municipal wastewater treatment systems (Wildman 2005).

Another type of wastewater treatment system, called the Living Machine, uses natural non-chemical biological methods to break down contaminants in domestic and industrial wastewater. It uses small organisms such as bacteria, fungi, plants, snails, clams, and fish and creates an ecosystem that can interact with the nutrients and soak up pollutants in the water, providing clean water as a byproduct. It provides an alternative to energy intensive chemical treatment and has been proven to be reliable treatment method (Findhorn Ecovillage 2008). Furthermore, the Advanced Integrated Wastewater Pond Systems (AIWPS) technology uses a series of ponds to treat wastewater. It uses algae photosynthesis in the ponds rather than mechanical aeration devices to produce oxygen that allows bacteria to break down contaminants in the wastewater. Compared to conventional wastewater treatment system, AIWPS is a more affordable and sustainable wastewater treatment technology that produces renewable energy through methane fermentation and biogas recovery (Green 1995).

Constructed soil filter technology is another approach to treating contaminants in municipal wastewater. It combines sedimentation, infiltration, and biochemical processes to remove suspended soils, organics, and inorganics from wastewater. Constructed soil filter technology does not require energy intensive mechanical aeration. Natural oxygen supply, microbial ecology, and weathered rock are the primary factors needed for this system (Kadam 2007). 
Providing sufficient circulation with diffused or mechanical aeration requires high levels of electricity, especially for facilities that treat wastewater with large surface areas. Solarpowered water circulators can be used in lagoon or municipal wastewater treatment systems to induce the flow of water from bottom to top, thereby increasing circulation without expending additional energy. Each solar-powered water circulator can substitute on average $22 \mathrm{~kW}(30 \mathrm{HP})$ of aeration equipment. Solar cells and battery provides continuous operation for up to three days. This technology performs best under steady state conditions (Dugger 2008).

Lastly, an emerging technology known as Blue Frog / Gold Frog reduces energy use by $50 \%$ compared to traditional aeration systems. Its unique microbubble circulation and stratification system helps to treat both insoluble and soluble $\mathrm{BOD}_{5}$ while reproducing a natural pond environment. Insoluble $\mathrm{BOD}_{5}$ sinks to the bottom and is anaerobically treated, while soluble $\mathrm{BOD}_{5}$ is treated with microbubbles at the surface (Dugger 2008). 


\subsection{Controls Systems}

Control systems play an important role in wastewater treatment facilities energy use and demand. Automated control systems require modernized operation management systems, advanced visualization of process information, remote monitoring, easy reporting, alarm detection, and incidence avoidance so that wastewater treatment facilities can meet increased monitoring and regulatory requirements while decreasing their energy use (Garbrecht 2008). Three main control system types typically encountered in wastewater treatment facilities are standalone controls, distributed control systems (DCS), and supervisory control and data acquisition systems (SCADA).

Standalone controls are the most basic level of systems which control individual equipment operations, heating, ventilating, and air-conditioning (HVAC) packaged systems, and small processes without requiring direct supervision (Partington 1998; Merritt 2008). Standalone control systems are convenient, programmable alternatives to expensive network systems and are typically easier to manage (Partington 1998). However, for large wastewater treatment facilities, this type of system may not be adequate in providing overall facility control.

DCS are more complex systems that consist of multiple direct control elements highlevel software (Merritt 2008). DCS control the flow of material through the facility processes using sensors, actuators, and setpoint controls (Applied Integration UK Ltd 2008). The communications backbone for this type of control system is a Local Area Network (Bentley Systems Inc. 2004). DCS systems are typically related to manufacturing and factory operations such as oil refining, petrochemicals, and central station power generation (Bentley Systems Inc. 2004; Applied Integration UK Ltd 2008). They generally have closed loop controls, resulting in real-time loop data being applied directly to an industrial controller without human intervention (Bentley Systems Inc. 2004).

SCADA systems are measurement and control systems that gather real-time data from remote locations and controls equipment, as well as operating conditions at the supervisory level (SCADA World 2007). Although SCADA systems generally function similarly to DCS, SCADA systems may not necessarily be located in the facility and instead use communications systems that are not as comprehensive as the local area network communication system (Bentley Systems Inc. 2004). SCADA systems are advanced control systems that are particularly applicable to wastewater treatment facilities and therefore will be of primary focus in this section.

\subsection{Overview of SCADA Systems}

The integration of SCADA systems in wastewater treatment facilities allows for faster data collection and analysis, and provides ways to improve facility performance (Sanchez 2005). SCADA systems have become increasingly applicable to wastewater treatment facilities as better control and monitoring of processes in wastewater industries have developed (ARC Advisory Group 2007). The current worldwide market for SCADA systems for water and wastewater industries is expected to increase at a compounded annual growth rate of 5.4\% from 2007 to 2012 (ARC Advisory Group 
2007). The introduction of centralized controls integrates existing standalone controls or distributed control systems, improving operational efficiency and facilitating the automation of demand response strategies. While the market for SCADA systems is growing steadily, no information was found at this time about the current level of penetration of SCADA systems in wastewater treatment facilities. One of the goals of LBNL's industrial facilities control survey is to increase the knowledge about the current level of penetration of the different control systems in wastewater treatment facilities.

The latest SCADA systems incorporate a new generation of technology and provide improved capabilities and functionalities (ARC Advisory Group 2007). For example, SCADA systems have evolved from a mainframe-based system to a client/ server system (Communication Technologies Inc. 2004). This has allowed the communications program to transmit data from the field to the master control unit (Communication Technologies Inc. 2004). Many SCADA protocols have also changed from a closed proprietary system to an open system that allows for operators to choose equipment that can meet the specific needs of the wastewater treatment facility (Communication Technologies Inc. 2004).

\subsubsection{SCADA System Structure}

SCADA systems are composed of several subsystems that monitor and control wastewater treatment operations. A typical SCADA system includes a Supervisory Control Station or master terminal unit (MTU), remote terminal units (RTUs), Human Machine Interface (HMI), interconnecting conductors for input/output (I/O) to the RTUs, a communication system, programmable logic controllers (PLCs), and software for monitoring and control of the entire system (Carns 1998). Figure 8 shows a principal scheme of the SCADA system.

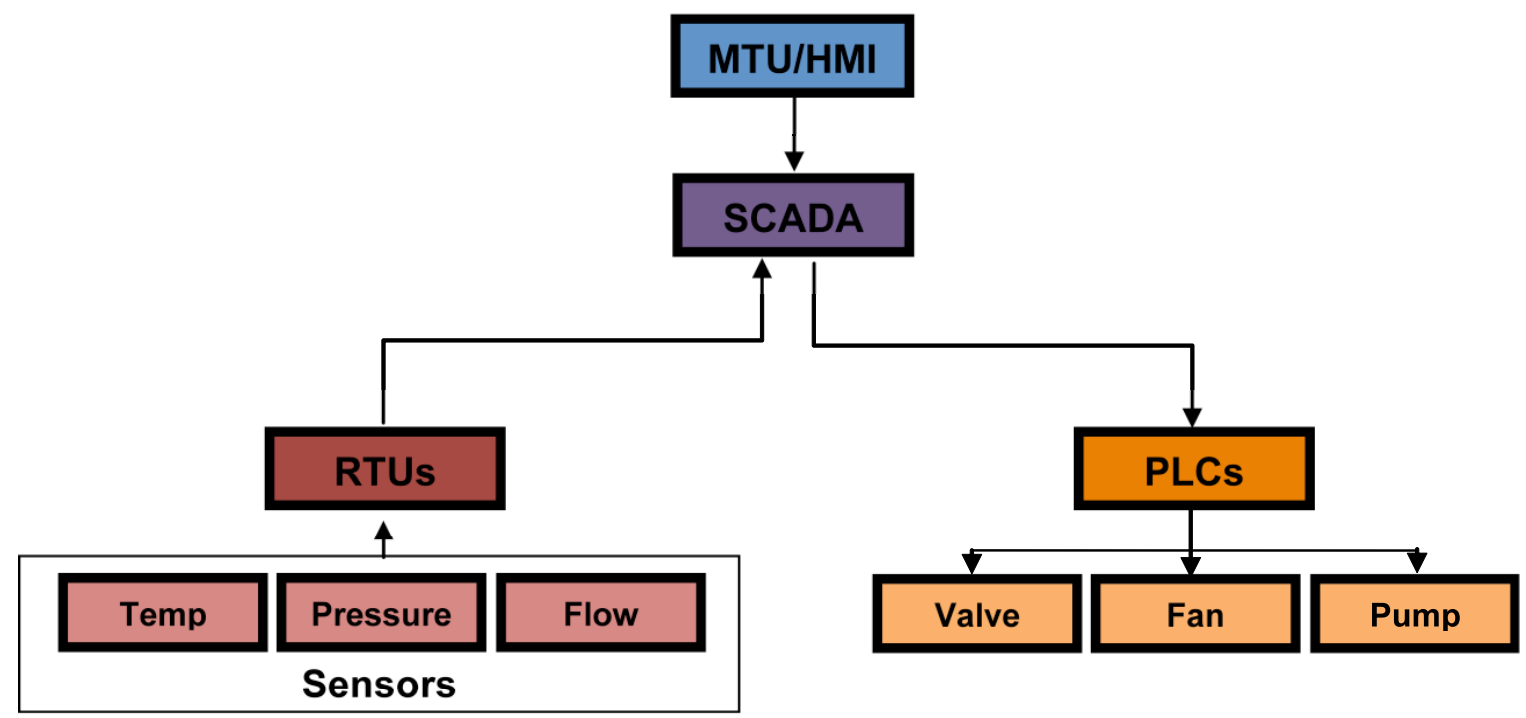

Figure 8. Principle Scheme of a SCADA System

The main components of a SCADA system include RTUs, MTUs that utilize HMI, and communications infrastructure. Data acquisition such as meter readings and equipment 
statuses are gathered at the RTU / PLC level and relayed to the SCADA system. The data is compiled and presented to an operator through the HMI. The operator can make supervisory decisions to adjust and over-ride preprogrammed RTU / PLC controls (Delhi College of Engineering 2007). Major components of SCADA systems are defined below:

MTU: A master terminal unit or server consists of one or more computers with operator interface capabilities. This is the central host computer. Operations such as starting or stopping pumps and opening or closing valves can be manually controlled from the MTU (Carns 1998). The MTU server communicates with HMI. This is done apart from the workstation or control room (SCADA World 2007).

HMI: The Human Machine Interface is the software used by the MTU and allows operators to receive process data in order to make facility operation decisions (SCADA World 2007). The HMI allows operators to have a facility-wide perspective of facility operations and collects crucial information such as alarms, events, and process variables (Sanchez 2005). Information from the I/O point is transmitted to the MTU, where it is converted to graphical displays. This allows operators to view and control process data such as flow, water pressures, and equipment operating conditions through displays that visualize the treatment process (Carns 1998; Sanchez 2005).

RTU: Remote Terminal Units are microprocessors with digital inputs and outputs that provide information on the status of the system and control the system. RTUs aid in monitoring, controlling equipment, and obtaining data from process equipment by converting electronic signals from field interface devices into the language used to transmit the data (Carns 1998; Communication Technologies Inc. 2004).

PLC: Programmable logic controls are electronic devices located close to the equipment that are capable of independently maintaining certain field conditions (Carns 1998), The basic PLC comprises of the central processing unit and the I/O system. The PLC interprets and implements software instructions, performs calculations and comparisons, makes logical decisions, and allows for communication within the system (Kogge 2008). PLCs are used to automate monitoring and control and cause logical procedures to be executed when certain field conditions are met (Communication Technologies Inc. 2004). Sometimes Proportional, Integral, and Derivatives (PID) may be used in place of PLCs. PIDs are a control loop feedback system designed to automatically adjust variables to hold measurements at set-points and to limit the need for constant operator supervision (ExperTune Inc. 2008).

\subsubsection{Applications of SCADA in Wastewater Treatment Facilities}

SCADA systems provide a central location for monitoring and controlling remote equipment (ARC Advisory Group 2007). Wastewater treatment operators can direct when to run specific equipment and make complex decisions with aid from the system (ARC Advisory Group 2007). SCADA systems optimize staff time and equipment use by providing continuous and precise control of process variables (ARC Advisory Group 2007). SCADA systems can start, slow down, or stop equipment when monitored process information such as flow rates and DO levels deviate from pre-established parameters (Carns 1998). Automatic adjustments will allow the treatment process to operate at optimum capacity and reduce costs for changing and upgrading equipment 
(Carns 1998). The use of advanced controls also prevent disturbances such as motor failure, increased DO levels, increased influent flow, and nutrient and chemical loading from industry discharges from resulting in costly maintenance and repairs (Sanchez 2005).

SCADA systems provide numerous benefits to wastewater treatment facilities such as the ability to monitor and control remote equipment, schedule operations, and automatically start and stop devices, which results in more efficient operation of aerators, blowers, pumps, valves, chemical feed systems, and other equipment (Carns 1998). SCADA is programmed to hold adjustable DO setpoints in order to monitor the treatment process. It utilizes a loop strategy to automatically adjust equipment in response to deviations from preset levels for $\mathrm{BOD}_{5}$, air density, blower efficiency, and facility flow (Zabrocki J. and P. Larson 2008).

These systems also reduce operating costs by decreasing the need for operators to be onsite during most hours of operation. Additionally, SCADA systems provide continuous and precise control of process variables, provide automatic data recording and report generation, monitor DO levels on a real-time basis, and meet discharge regulations with better control at the treatment level (Carns 1998). Although the capital costs of automated systems can be large, they are mostly offset by electrical savings, particularly at larger facilities (Carns 1998).

Newer industrial facilities use a variety of advanced technologies such as state-of-the-art online instrumentation for real-time monitoring, advanced control systems, and troubleshooting (Means 2004). These current technologies have not yet been fully adopted into the treatment and processing of municipal wastewater. Advanced controls and online instrumentation may improve performance and energy efficiency of municipal wastewater treatment facilities, many of which are outdated or have reached maximum capacity (Means 2004).

\subsection{Wastewater Treatment Equipment Controls}

While SCADA systems provide overall facility control, it is also important to understand how the individual equipment in wastewater treatment facilities is controlled. Setpoints for parameters such as desludging times and DO levels can be altered within design limits. Identifying controls in individual wastewater treatment equipment and opportunities for the implementation of centralized control systems is a key step in reducing facility energy use, demand, and operating costs.

Low-cost electronics and data communications systems that are being applied to field devices such as pumps, valves, sensors, and operator interfaces are leading to both increased control consolidation and more distributed control (Jenkins 1996). Installing variable frequency drives (VFDs) in wastewater treatment facilities can save a significant amount of energy and reduce facility operating costs. Conventional alternating current motors operate at a constant speed when powered at a constant frequency $(60 \mathrm{~Hz})$; VFDs can allow the frequency and voltage to be varied in the motor, resulting in varied speed (Carns 1998). Typically VFDs can be installed on variable load equipment which currently operates and runs on a constant speed (Jenkins 1996). Two key energy 
consuming devices in wastewater treatment facilities are pumps and aerators. VFDs adjust the speed of electric motors and monitor power being delivered to the equipment (Environmental Protection Agency 2006).

Pumps: Pumps can be controlled directly by a PLC or through a SCADA system. Variable speed controls more efficiently match the pump output to system head requirements. Since a fixed speed is no longer required, it allows for greater pump operating range and improved operating efficiency. In main pumps at wastewater treatment facilities, it is better to have uniform flow rather than a single pump turning on and off (Energy Conservation Task Force of the Water Environment Federation 1997). SCADA systems can recognize and prevent pumps from operating under difficult conditions, which may reduce the amount of operational failures (ITT Corporation 2007). Within the SCADA system configuration, the PLCs can be installed remotely on each feed pump to implement control commands. The PLCs may be separated into several remote units mounted close to the equipment and connected to the SCADA's MTU by a communications network. This type of control configuration also reduces the impact on the entire facility of a single controller failure (Jenkins 1996).

Aerators: Automatic DO control on an aeration control systems can reduce facility energy by as much as 25\% (Environmental Protection Agency 2008). The control system automatically adjusts blower output at preset time intervals based on a comparison between an average of DO readings in the aeration basins and a recommended DO concentration (Carns 1998). Automatically adjusting the air volume to the optimal required amount reduces the demand on blower motors and results in lower energy use (Environmental Protection Agency 2008).

There are different control strategies for different types of blowers. Aerators utilize blowers to control DO levels. DO probes can be connected via an instrumentation panel or SCADA system to automatically control the aeration blowers (Carns 1998). DO levels are controlled by manipulating the amount of air delivered to each aeration zone. The zone having the greatest air demand determines the air pressure set point (Zabrocki J. and P. Larson 2008). DO sensors are located in strategic locations to transmit signals to the controlling SCADA-RTU (Zabrocki J. and P. Larson 2008). Blower speeds can also be adjusted to accommodate varying loads during different periods of the day or unexpected events (Zabrocki J. and P. Larson 2008).

The amount of DO in wastewater must be sufficient in order for aerobic aquatic organisms such as invertebrates and fish to survive (National Estuarine Research Reserve System 2004). Two ways of measuring and monitoring DO are known as galvanic and polarographic. The galvanic and polarographic probes use an electrode system where the DO reacts with the cathode to produce a current. The magnitude of the current gives a direct measure of the amount of oxygen entering the probe.

Although automatic DO control systems can save approximately $25 \%$ of the energy needed for aeration, they have not been used in many facilities for several reasons (Jenkins 1996). One reason is because older probes and sensors used in these systems for measuring DO levels need frequent maintenance (Jenkins 1996). However, newer sensor technology and self-cleaning probes have fixed this problem (Jenkins 1996). Wastewater 
treatment facilities should consider the addition of variable capacity blowers and automated DO control when replacing any aeration system with fine-bubble diffusers (Carns 1998).

Disinfection Equipment: UV disinfection is becoming a common method of disinfection, because unlike traditional processes such as chlorination and ozonation, UV disinfection does not involve the addition of chemicals (Carns 1998). However, UV disinfection uses more electrical power than the chemical methods of chlorine disinfection. Implementing control strategies can help minimize the impact of energy costs from utilizing UV disinfection (Carns 1998). Generally, control systems input information into either a local PLC or the overall facility SCADA system. Control data information for the SCADA system can allow facilities to respond to quick changes in the system such as increased levels of TSS, turbidity, and $\mathrm{BOD}_{5}$. They can anticipate cleaning frequencies and allow the wastewater treatment system to respond to these changes (Carns 1998).

New on-line sensing technologies can also reduce the power costs associated with UV disinfection. Turbidity sensors and UV absorbance sensors can automatically control the power applied to UV systems and optimize UV disinfection while eliminating unnecessary power consumption and extending the life of expensive UV lamps (ITT Corporation 2007).

Motorized Valves: Motorized valves balance the flow of air between each aeration basin and the zone within each basin and are used in municipal wastewater treatment facilities to deal with the changing organic loads in the aeration process. Accurate amount of air supply that continuously and automatically adjusts to the optimal required amount can reduce facility energy consumption by as much as $25 \%$, thereby reducing the demand on blower motors (Environmental Protection Agency 2008).

In each treatment stream, there are a number of stabilization zones and contact zones for DO control. In each zone, there is a head pipe that contains a motor-operated valve whose position is automatically modified to maintain the proper balance of air that is applied to each treatment zone. As in the case of using VFDs to control the aerators, the motorized valves are able to maintain an efficient DO concentration in each aeration zone (Zabrocki J. and P. Larson 2008). Similarly, to control the water flow, automatically controlled flow-regulating devices (motorized valves) can also be used in flow equalization, instead of using pumping to manage additional head requirements (Metcalf \& Eddy Inc. 2003).

Sensor maintenance will improve effectiveness of energy saving measures. Sensors should be properly maintained and calibrated, and operators should be trained to work with the automation system to avoid unnecessary energy expenditures (Pakenas 1995).

In conclusion, centralized control systems make wastewater treatment facilities excellent candidates for OpenADR by bringing together the actions of the individual equipment controls and locally distributed controls. Such integration allows the OpenADR infrastructure to interact with a single control system, creating a cost-effective and easy to manage reliable base for OpenADR implementation. Centralized systems assist communication between higher-level controls and lower-level hardware, facilitating the 
implementation of OpenADR strategies. Such integration could be a powerful tool for wastewater treatment facilities when developing energy efficiency and demand response programs. 


\subsection{Energy Efficiency and Demand Response Opportunities}

Energy efficiency and demand response are key strategies to reducing energy use and demand, which represent $28 \%$ of operating expenses in wastewater treatment facilities (Means 2004). Factors such as effluent regulations, electricity use and demand, efficiency characteristics of different equipment, and operating schedules are important when implementing energy efficiency improvements and OpenADR strategies. Energy efficiency upgrades can improve facility operation and provide a base for the implementation of demand response strategies. OpenADR strategies can be implemented as an enhanced use of upgraded equipment and facility control strategies installed as energy efficiency measures. Conversely, installation of controls to support OpenADR may result in improved energy efficiency through real-time access to operational data (Piette 2007; Kiliccote 2008).

A possible "natural path" to develop OpenADR capabilities in the facilities is to take advantage of the replacement of equipment at the end of its lifetime. This is particularly applicable for key equipment such as pumps, fans, and controls. Individual wastewater treatment facilities may look for a window of opportunity in the near future when a substantial fraction of their equipment is nearing the end of its useful life. Such an opportunity may allow the facility to introduce ADR enabled equipment on a large scale, triggering a technological shift of a magnitude that would not be seen from incremental improvements. While identifying the equipment turnover opportunity in California wastewater treatment facilities is beyond the scope of this study, further research into the age distributions for wastewater treatment equipment and controls to determine the potential impact of this approach would be a useful follow-up study.

\subsection{Energy Efficiency Opportunities}

Energy efficiency measures reduce overall energy use and decrease operating costs. Implementing energy efficiency measures reduces overall energy use while providing the same level of service. Although this study does not assess the cost, most measures could be implemented cost-effectively, depending on specifics in each facility. Energy efficiency measures in wastewater treatment facilities include managing equipment efficiency, installing VFDs on fan and pump motors, maintaining flow equalization, retrofitting HVAC, managing storm water, and generating energy on-site.

\subsubsection{Equipment Efficiency}

Wastewater treatment facilities can reduce energy use by replacing or retrofitting existing equipment with high-efficiency and better-sized equipment, particularly as equipment reaches the end of its useful life. Purchasing high efficiency pumps and motors can reduce wastewater treatment facility energy use, as pumps and aeration systems can contribute 50-90\% of the total energy use (Jenkins 1996; Department of Environmental Protection Bureau of Land \& Water Quality 2002; Environmental Protection Agency 2006). While this strategy could be capital-intensive, it could be costeffective over the life-cycle of the equipment. 
Aerators: Aerators account for a large portion of energy use in wastewater treatment, so improving aerator efficiency while maintaining sufficient oxygen transfer throughout the lagoon will significantly reduce energy use (Aqua Sierra Inc. 2000). There are two main types of aerators used in the wastewater treatment process. Mechanical aeration uses surface agitators to vigorously mix the sewage, creating small bubbles of air (Carns 1998). Oxygen is needed for the decomposition of organic matter and to manage the $\mathrm{BOD}_{5}$ levels and suspended solids in the wastewater stream (Aqua Sierra Inc. 2000; Metcalf \& Eddy Inc. 2003). Mechanical aeration systems are less energy efficient than diffused aeration systems (Carns 1998).

A diffused aeration system releases oxygen from the floor of the aeration tank and disperses bubbles of air into the sewage (Aqua Sierra Inc. 2000). Diffused air systems can be either coarse-bubble or fine-bubble. Fine pore diffusers, also called fine-bubble diffusers, have greater surface area for transferring oxygen to wastewater and are more efficient than coarse-bubble diffusers in aeration systems (Carns 1998).

Adjusting blowers and aerators to operate at a lower capacity will reduce both facility energy use and demand. In a typical wastewater treatment facility with a diffused aeration system, $50-90 \%$ of electricity is used to run aerator blower motors (Jenkins 1996). Energy-efficient aerator motors provide improved performance and substantial energy savings, when compared to standard motors (Carns 1998). Blower and pump motors can account for more than 75-80\% of a wastewater treatment facility's energy use, so high-efficiency motors can greatly improve the efficiency of the system (Department of Environmental Protection Bureau of Land \& Water Quality 2002; Environmental Protection Agency 2006). Further, blower and pump motors can be staged to better utilize the available blower or pump capacity.

Additionally, installing VFDs on the aerator blower motors can reduce the energy use by operating equipment at lower speeds and allowing for better control of processes when high aeration levels are not required (Carns 1998). Blower energy consumption with VFDs is typically 10-20\% lower than when using conventional controls (Jenkins 1996), which can lead to a considerable reduction of both energy use and demand (Hemert 2006).

Solar aerators improve DO levels and water quality in ponds, and reduce bacteria and nutrient buildup while lowering electrical costs (Hayden 2007). Solar aerators run automatically with an average run time of 20 hours per day (Kelo Technology). Currently, only $6 \%$ of wastewater treatment facilities use solar aerators (BASE Energy Inc. 2006), however, they are becoming more widely used in wastewater ponds where they handle smaller effluent loads.

Pumps: Pumps are used in the majority of wastewater treatment processes, including influent pumping, grit pumps, and air lift pumps (Metcalf \& Eddy Inc. 2003). The energy consumption of a pumping station can be reduced by retrofitting either the pumps or the systems to which they are connected (Carns 1998). Pumps require large amounts of energy to collect and move wastewater to wastewater treatment facilities. Pump efficiency can be improved by lowering the head that a pump must work against or reducing pump discharge (Energy Conservation Task Force of the Water Environment 
Federation 1997). The pump head results from lifting water or overcoming friction and can be reduced to minimize energy use (Energy Conservation Task Force of the Water Environment Federation 1997). Depending on the wastewater treatment facility elevation and influent sewer elevation, the energy required for wastewater pumping alone can represent 15-70\% of the total wastewater treatment facility energy, but is more likely to fall at the lower end of the range (as seen in Figure 7) (Energy Conservation Task Force of the Water Environment Federation 1997; Kleyman 2006). Pump efficiency can be improved by minimizing the amount of wastewater that is transferred through the collection system (Energy Conservation Task Force of the Water Environment Federation 1997). In addition, regular maintenance, such as checking air-release valves to correct air blockages and cleaning of pumps, maintains pump efficiency, and extends equipment lifetime (Energy Conservation Task Force of the Water Environment Federation 1997).

Pumps are often oversized for the average wastewater flow and are thus operated inefficiently (Carns 1998). Wastewater treatment facilities frequently address inefficiencies due to pump oversizing by applying operational strategies that involve staging multiple pumps which allows for more efficient utilization of pumping capacity (Department of Energy 2006).

Similarly, installing VFDs on existing pumps will decrease the energy usage and will allow for greater pump efficiency, particularly if the average flows vary significantly (Carns 1998). VFDs can reduce pump energy use by as much as 50\% (Environmental Protection Agency 2006). A frequently recommended practice for pump optimization is staging multiple pumps and using a single pump equipped with a VFD as a trim pump. This shows that in installations with multiple pumps, VFDs may not be need to be installed on each pump (U.S. Department of Energy Energy Efficiency and Renewable Energy 2007)

Installing VFDs on centrifugal pumps is also likely to result in large energy savings (Offik 2006). Centrifugal pumps are commonly used in wastewater treatment facilities for grit and scum removal, handling primary sludge, trickling filters, waste-activated sludge, and digested biosolids (Metcalf \& Eddy Inc. 2003). VFDs commonly manage variable flows that must meet changing process demands and are more efficient for centrifugal pumps compared to control valves (Offik 2006).

Implementing these energy efficiency measures on energy-intensive equipment, such as pumps and aerators, can greatly reduce facility energy use. In addition, proper maintenance can extend equipment lifetime and improve energy efficiency (Environmental Protection Agency 2008).

\subsubsection{Flow Equalization}

Influent wastewater flow varies daily and seasonally. Process units and equipment have to be large enough to meet the daily and seasonal peak demands (Energy Conservation Task Force of the Water Environment Federation 1997). Equalization basin drains open and close as needed to maintain a constant level in the influent wet well, which creates a near-constant flow through the treatment process, improving pumping efficiency (Carns 1998). This reduces peak demand and energy consumption, and improves the overall 
treatment process (Carns 1998). However, building storage basins can be expensive, so unused tanks can be converted into equalization basins during upgrading and expanding facilities (Energy Conservation Task Force of the Water Environment Federation 1997). Flow equalization results in an overall improvement in wastewater treatment facility efficiency, more consistent removal rates, reduced peak-demand charges, and decreased power consumption (Energy Conservation Task Force of the Water Environment Federation 1997).

\subsubsection{Lighting and Heating, Ventilating, and Air Conditioning}

Lighting and heating, ventilating, and air-conditioning (HVAC) systems can be retrofitted to save facilities energy and reduce overall energy demand and operating expenses. Improved fluorescent bulb technology offers higher-quality lighting and uses less energy (Environmental Protection Agency 2008). Energy-efficient lighting systems have occupancy sensors and controls that will automatically turn off lights in unoccupied rooms (Environmental Protection Agency 2008). HVAC system efficiency can be improved through installing energy-efficient systems, increasing envelope insulation, sealing leaks, properly sizing the system, and utilizing temperature controls (Environmental Protection Agency 2008).

\subsubsection{Storm Water Management}

An interesting opportunity for reducing energy use in municipal wastewater treatment is to improve storm water management. During rainy weather, large amounts of runoff ends up in municipal wastewater systems (California Energy Commission 2005). During winter storms, sewer systems treat twice the amount of wastewater compared to dry summer months (California Energy Commission 2005). Electricity use to treat the wastewater is proportionate to these flows so the energy usage in wastewater treatment facilities is often nearly twice as high in winter than in summer (California Energy Commission 2005). The implementation of storm water management measures needs to be carefully weighed against the overall benefits of reducing the wastewater treatment load.

The California State Water Resources Control Board currently implements the state's storm water management program, which regulates storm water discharges from municipal sewer systems, construction, and industrial activities (California Department of Water Quality 2008; Environmental Protection Agency 2008). Many municipalities have storm water programs with their own additional treatment requirements. These requirements are designed to protect surface waters from harmful pollutants that may be present in storm water runoff (Environmental Protection Agency 2008).

\subsubsection{Facility-Based Energy Sources}

Opportunities to utilize facility-based energy sources can help wastewater treatment facilities reduce the amount of purchased power, thus reducing costs and ensure environmental protection during interruption of supply. Although not useful for reducing total facility energy use, facility-based energy sources can be used during demand response events to reduce electricity demand on the grid. These energy sources include cogeneration and fuel cells. 
Onsite Power Generation: Power can be generated onsite at a wastewater treatment facility by burning digester gas produced during the anaerobic digestion process. This also produces waste heat that is used for process heating as well as space heating (Electric Power Research Institute 1994). Fuel efficiency can increase from 30 to $70 \%$ by recovering waste heat and using it for space heating and cooling (Environmental Protection Agency 1995). Wastewater treatment facilities that have or are planning to install anaerobic digesters should consider cogeneration as a reliable and cost-effective option to generate electricity.

In the United States, about $22 \%$ of wastewater treatment plants use anaerobic digesters. However, most facilities flare the biogas produced; less than $1 \%$ of facilities currently use biogas recovery (Global Energy Partners LLC 2007). In California, currently only ten municipal wastewater treatment facilities generate $38 \mathrm{MW}$ of electrical power, even though there are 220 municipal wastewater treatment facilities with the potential to recover up to $36 \mathrm{MW}$ from anaerobic digesters (California Energy Commission 2008). However, most of the municipal treatment sites have a potential for cogeneration of less than $1000 \mathrm{~kW}$ (California Energy Commission 2008). In addition, there are 168 municipal treatment facilities that have a biogas to electricity potential of less than $200 \mathrm{~kW}$ (California Energy Commission 2008). On-site cogeneration is commonly utilized by the food processing industries, however, no reports about data regarding the potential magnitude for cogeneration in food processing treatment facilities were found at this time.

Fuel Cells: Fuels cells are another type of power source that generate heat that can later be recovered and used as a source of electricity (Environmental Protection Agency 2006). Fuel cells convert chemical energy to electrical energy by combining oxygen with hydrogen from fuel. Hydrogen fuel can be supplied either as pure hydrogen gas or through a fuel reformer that converts fuels such as methanol, natural gas, or gasoline into hydrogen-rich gas (Environmental Protection Agency 2008). While it works much like a conventional battery, fuel cells are not charged prior to use. Chemical reactants continuously feed into the cell, providing constant power output (Environmental Protection Agency 2006). Heat from the process can also be recovered and used in the facility (Environmental Protection Agency 2006). Fuel cells can convert $40 \%$ of the energy in digester gas into electricity and is more efficient than cogeneration (California Energy Commission 2000). Carbon monoxide emissions from fuel cells are well below California emissions standards for combustion engines (California Energy Commission).

Hydropower: Hydropower turbines for low-head effluent can be used to generate electricity in wastewater treatment facilities (Pakenas 1995). Treated effluent, instead of going directly into the outfall pipeline, can instead pass through turbine-generator units before flowing into the receiving water body (Pakenas 1995). The electricity generated by the passing of effluent through the turbine-generators is delivered to the wastewater treatment plant through an independent transmission line that connects to the wastewater treatment plant electric distribution system (Pakenas 1995). During times of hydropower system shutdown or excessive flows, the effluent can flow through the outfall pipeline without going through the hydropower turbine generators (Pakenas 1995). 
Energy extraction from municipal effluent streams can be classified as low power hydropower. Low hydropower facilities have a capacity of generating $100 \mathrm{~kW}$ to $30 \mathrm{MW}$ (Department of Energy 2003). A study done by NYSERDA found that an effluent flow of 227 million liters per day (60 MGD) with a head of 15 meters (50 feet) or a flow of 757 million liters per day (200 MGD) at 4.6 meters (15 feet) of head can provide $300 \mathrm{~kW}$ of generating capacity. Table 17 shows the energy output from effluent hydropower as a function of head and flow. Wastewater treatment facilities in the highlighted range of discharge flow and head conditions may be able to construct and operate an effluent hydropower project for less than $\$ 0.06$ per $\mathrm{kWh}$, which was projected to be a costeffective range (Pakenas 1995). As electricity prices rise, more combinations of head and flow will prove to be cost-effective.

Table 17. Effluent Hydropower- Kilowatt Output as Function of Head and Flow

\begin{tabular}{|c|c|c|c|c|c|c|c|c|c|c|}
\hline \multirow[b]{2}{*}{$\begin{array}{c}\text { Discharge } \\
\text { Flow(ML/day } \\
\text { (MGD)) }\end{array}$} & \multicolumn{10}{|c|}{ Head (meters (ft)) } \\
\hline & $\begin{array}{l}1.5 \\
(5)\end{array}$ & $\begin{array}{c}3 \\
(10)\end{array}$ & $\begin{array}{c}4.6 \\
(15)\end{array}$ & $\begin{array}{c}6.1 \\
(20)\end{array}$ & $\begin{array}{c}7.6 \\
(25)\end{array}$ & $\begin{array}{c}9.1 \\
(30)\end{array}$ & $\begin{array}{l}10.7 \\
(35)\end{array}$ & $\begin{array}{l}12.2 \\
(40)\end{array}$ & $\begin{array}{l}13.7 \\
(45)\end{array}$ & $\begin{array}{l}15.2 \\
(50)\end{array}$ \\
\hline $40(10)$ & 5 & 10 & 16 & 21 & 26 & 31 & 37 & 42 & 47 & 52 \\
\hline $80(20)$ & 10 & 21 & 31 & 42 & 52 & 63 & 73 & 84 & 94 & 105 \\
\hline $110(30)$ & 16 & 31 & 47 & 63 & 79 & 94 & 110 & 126 & 142 & 157 \\
\hline $150(40)$ & 21 & 42 & 63 & 84 & 105 & 126 & 147 & 168 & 189 & 210 \\
\hline $190(50)$ & 26 & 52 & 79 & 105 & 131 & 157 & 184 & 210 & 236 & 262 \\
\hline $230(60)$ & 31 & 63 & 94 & 126 & 157 & 189 & 220 & 252 & 283 & 315 \\
\hline $270(70)$ & 37 & 73 & 110 & 147 & 184 & 220 & 257 & 294 & 330 & 367 \\
\hline $300(80)$ & 42 & 84 & 126 & 168 & 210 & 252 & 294 & 336 & 378 & 420 \\
\hline $340(90)$ & 47 & 94 & 142 & 189 & 236 & 183 & 330 & 378 & 425 & 472 \\
\hline $380(100)$ & 52 & 105 & 157 & 210 & 262 & 315 & 367 & 420 & 472 & 525 \\
\hline $420(110)$ & 58 & 115 & 173 & 231 & 288 & 346 & 404 & 462 & 519 & 577 \\
\hline $450(120)$ & 63 & 126 & 189 & 252 & 315 & 378 & 441 & 504 & 566 & 629 \\
\hline $490(130)$ & 68 & 136 & 205 & 273 & 341 & 409 & 477 & 545 & 614 & 682 \\
\hline $530(140)$ & 73 & 147 & 220 & 294 & 367 & 441 & 514 & 587 & 661 & 734 \\
\hline $570(150)$ & 79 & 157 & 236 & 315 & 393 & 472 & 561 & 629 & 708 & 787 \\
\hline $600(160)$ & 84 & 168 & 252 & 336 & 420 & 504 & 587 & 671 & 755 & 839 \\
\hline $640(170)$ & 89 & 178 & 267 & 357 & 446 & 535 & 624 & 713 & 802 & 892 \\
\hline $680(180)$ & 94 & 189 & 283 & 378 & 472 & 566 & 661 & 755 & 850 & 944 \\
\hline $720(190)$ & 100 & 199 & 299 & 399 & 498 & 598 & 698 & 797 & 897 & 997 \\
\hline $760(200)$ & 105 & 210 & 315 & 420 & 525 & 629 & 734 & 839 & 944 & 1049 \\
\hline
\end{tabular}

Source: Pakenas, L. J. (1995). Energy Efficiency in Municipal Wastewater Treatment Plants, NYSERDA.

One example of successful hydropower production can be seen at San Diego's Point Loma wastewater treatment plant, which treats 662 million liters (175 million gallons) of wastewater per day and serves a population of more than 2.2 million residents. Two methane gas digesters help supply the facility's energy needs, making Point Loma an energy independent site (City of San Diego). The facility also produces an additional 
1.35 MW of power by operating a hydro-generator at the outfall pipe. This is possible due to the 27 meters (90 feet) elevation drop from of the effluent outfall from the wastewater treatment facility (City of San Diego).

\subsection{Demand Response Opportunities}

Wastewater treatment facilities which have implemented energy efficiency measures are excellent candidates for OpenADR for both technical and managerial reasons. Since energy efficiency measures already address existing opportunities for reducing energy use and demand on a permanent basis, they can serve to establish a base for implementing demand response strategies. Control technologies installed for energy efficiency and load management purposes can often be adapted for OpenADR at little additional cost. In addition, facilities which have already achieved success in energy efficiency and load management may also be more receptive to demand response because their ability to realize benefits from managing their energy use has already been demonstrated. In addition, process automation controls installed, particularly for load management, may provide access to the real-time data needed to determine the impact of OpenADR, and how it effects process performance in real-time.

Demand response strategies modify facility electricity use during utility peak periods in order to enhance system reliability, respond to market conditions and pricing, and improve the utilization of the facility infrastructure. The degree to which demand response strategies can be automated is dependent upon the level of integration of the facility control technologies. Although this study does not assess the cost of implementing each demand response opportunity, based on the experience with demand limiting measures, it appears that many measures could be implemented costeffectively, depending on specifics in each facility.

Site electrical loads during peak periods can be reduced by a variety of strategies, which can be grouped into two categories: load shedding and load shifting. These strategies could be part of either facility load management program or be performed as part of OpenADR activities. Demand limiting programs involve daily time-of-use energy management techniques that include careful consideration by a facility of any potential to schedule equipment to avoid increasing peak facility electricity loads, to "smooth out" the facility's electricity load curve. Load shedding and load shifting strategies, as components of OpenADR programs, are designed to respond to the occasional need to reduce electricity use during times of peak utility load-- also known as DR events. Load shedding strategies reduce the facility's total electricity load during DR events, and load shifting strategies change the time of electricity demand to off-peak hours. Figure 9 illustrates the difference in a representative load shape when implementing load shedding and load shifting strategies in the cases of both demand limiting and OpenADR. Demand response strategies need to be structured so as to limit a significant demand increase above baseline levels after the demand response period, except when part of a planned shift strategy. Appropriate control strategies should be applied to reduce sharp demand rebounding by staging equipment affected in the demand response measure. 


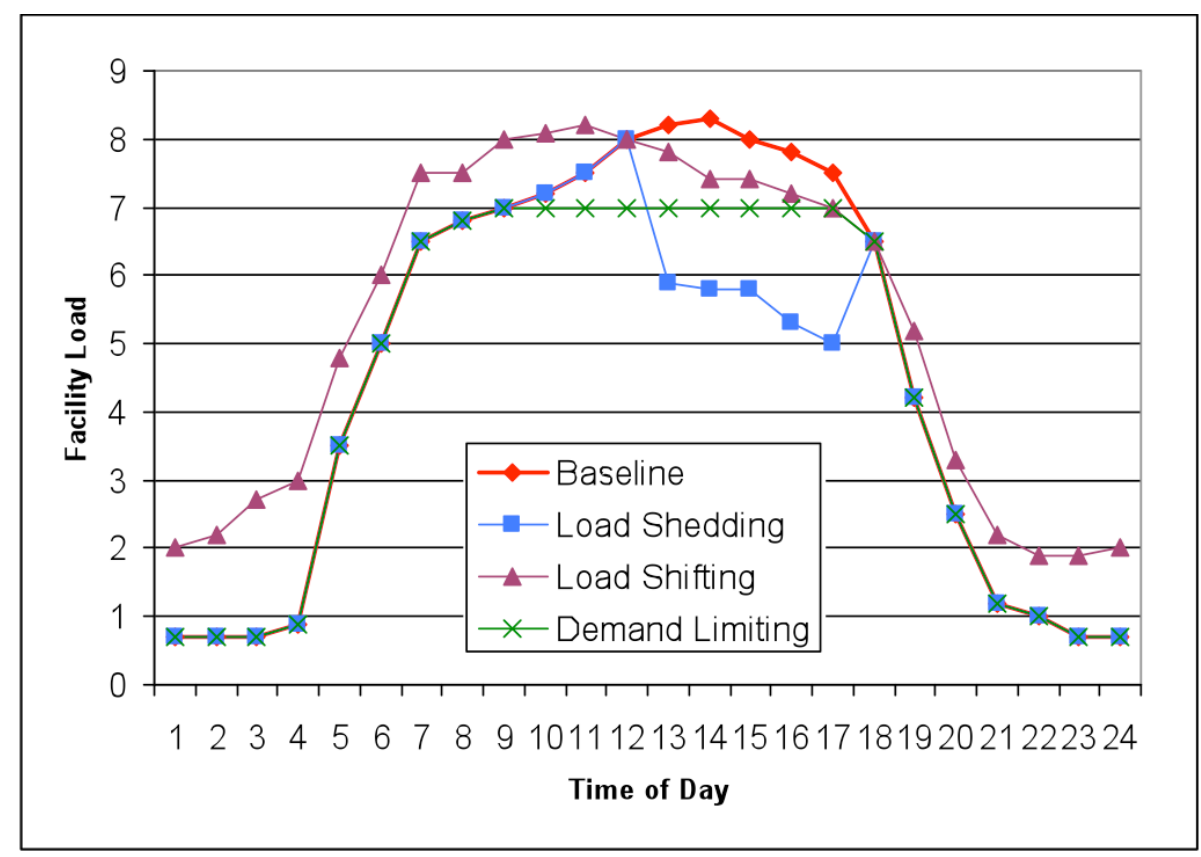

Figure 9. Examples of Load Reduction Strategies ${ }^{1}$

\subsubsection{Load Shifting}

Load shifting reschedules the time of electricity demand to off-peak hours. This can be done only during demand response events or conducted regularly as a load management strategy. Electrical load management is a frequently used method for reducing energy use in wastewater treatment facilities and can result in 10-15\% energy savings (Carns 2004). Real-time facility control is crucial when implementing load management strategies since electric rates are expected to vary hourly and even continuously (Carns 1998). Load shifting strategies in wastewater treatment facilities include pre-aeration, utilizing storage capacity, and scheduling dewatering, anaerobic digestion, and backwash filters process to off-peak periods.

Over-oxygenation: Aeration is a significant consumer of energy in the wastewater treatment process (Energy Conservation Task Force of the Water Environment Federation 1997). Over-oxygenation involves over-aerating wastewater prior to a demand response event, so a facility can reduce aeration needs during the peak demand periods. A recent study performed a theoretical assessment of over-oxygenation in a California food processing wastewater treatment facility, and found that a $10 \%$ peak load reduction would result in a DO decrease of $0.2 \mathrm{mg} / \mathrm{L}$ (Lewis 2009). Facilities should monitor effluent to ensure that over-oxygenation meets their facility and operational needs. Dissolved oxygen can inhibit denitrification if concentrations are above $0.2 \mathrm{mg} / \mathrm{L}$ (Metcalf \& Eddy Inc. 2003). Also, excessive air input once effluent reaches maximum DO concentration should be avoided to prevent unnecessary energy use (Electric Power

\footnotetext{
${ }^{1}$ This chart is conceptual; the data are not from actual measurements.
} 
Research Institute 1994). DO levels above $4 \mathrm{mg} / \mathrm{L}$ do not significantly improve operation, but greatly increase energy use (Metcalf \& Eddy Inc. 2003). Also, facilities must carefully monitor oxygen levels to assure that the regulation requirements are met.

Storage: Wastewater treatment facilities can utilize facility storage capacity to store untreated wastewater and process it during off-peak hours. By collecting incoming wastewater at high peak hours and processing it during off-peak hours, wastewater treatment processes can be rescheduled to off-peak hours (ITT Corporation 2007). If a storage system is not already in place, it may not be cost effective to construct a storage facility specifically to process wastewater and sludge during off-peak hours. Further cost and benefits analysis of wastewater storage and electricity pricing should be developed.

Wastewater treatment facilities can use equalization basins, stock ponds, or lagoons to store wastewater until it can be processed during off-peak hours (Environmental Protection Agency 2006). However, many facilities are not equipped with adequately sized excess storage, and building additional storage space can be expensive, so unused tanks can be converted into equalization basins during facility upgrades and retrofits (Energy Conservation Task Force of the Water Environment Federation 1997). Although facilities have operational flexibility with storage systems, water quality must be carefully monitored, for example, industrial wastewater treatment facilities should avoid storage of wastewater containing reactive chemicals because it can affect pumps and other equipment. A major obstacle to using storage as a demand response strategy is the very high capital investment to build storage areas (Energy Conservation Task Force of the Water Environment Federation 1997).

Rescheduling Processes: Facility processes can be rescheduled to off-peak times and equipment can be turned off during peak operation hours. Processes such as biosolids thickening/ dewatering and anaerobic digestion can be rescheduled for operation offpeak and partial-peak rate periods (Electric Power Research Institute 1994; Carns 1998).

Backwash Filter Pumps: Backwashing removes solids that have accumulated in the filtration system (Siemens Water Technologies 2006). Operating backwash pumps during off-peak hours can significantly reduce energy use in wastewater treatment facilities (Electric Power Research Institute 1994). However, this strategy depends on the wastewater turbidity being low enough to allow continuous operation of the filters during on-peak hours without backwashing (Electric Power Research Institute 1994). Filter instrumentation allows for greater control over backwash operations by providing facility operators data on backwash water flowrate, air flowrate, and turbidity (Metcalf \& Eddy Inc. 2003). The implementation involves the installation of control systems to monitor the filter-status parameters which are used to initiate backwash, and includes the capability to forecast these parameters to initiate the backwash prior to a demand response event.

\subsubsection{Load Shedding}

Load shedding involves curtailing energy demand during a demand response event. Load shedding strategies in wastewater treatment facilities include utilizing VFDs to operate equipment at reduced capacities, shutting down unnecessary equipment, and operating standby generators. 
Operation at Reduced Equipment Capacity: Load shedding can be accomplished during a demand response event by staging equipment or utilizing equipment with VFD capabilities. Staging equipment can be utilized as a potential demand response strategy if the facility has a number of pumps installed in parallel. Operating a pump with a properly-sizedVFD offers a more flexible and accurate way of reducing equipment capacity to match load. Operating VFDs on pumps and aerator blowers can reduce electricity demand during demand response periods. VFDs allow for energy consuming equipment to run at lower capacities. VFDs can shed electricity load for wastewater treatment facilities by reducing pump or aerator energy demand during peak hours. Due to the high energy requirements of pumps and aerator blowers, VFDs can have a significant impact on facility electricity demand.

Shutting down equipment: During peak demand periods, facilities can shut down aerator blowers, pumps, HVAC, and other equipment to shed their electrical load. Shutting down equipment can run the risk of lowering the quality of the treated wastewater; therefore, careful monitoring of the wastewater stream is necessary when applying this strategy.

Standby Generators: Standby generators are another viable energy source for wastewater treatment facilities. Since storage is often not an option in water supply systems, most of the stations are equipped with a standby or redundant power source such as enginegenerators (Wilkinson 2000). Regulatory agencies may also require installation of standby units to maintain system reliability (Wilkinson 2000). Engine generators are important sources of energy because system pumping stations need to be operational at all times, particularly during peak flow conditions (Wilkinson 2000). However, for many on-site fuel sources, air quality regulations must be considered (Carns 1998; Menn 2001). Potential savings by using this method are 10-15\% greater than cogeneration (Electric Power Research Institute 1994). SCADA system real-time demand monitoring and alarm system can provide wastewater treatment facilities with an automatic transfer switch to run standby power during peak demand periods (Carns 1998).

While air-quality issues are a concern when using diesel fuel, standby generators can also be powered using anaerobic digester gas. Many facilities that produce and flare anaerobic digester gas, can install digester gas covers to store excess gas and use it to power standby generators during periods of peak electricity demand. 


\subsection{Case Studies}

Several wastewater treatment facilities documented the implementation of load management and energy efficiency measures. The implementation of these measures clearly indicates the potential for participation in demand response activities. The following case studies illustrate best practices measures implemented in several California wastewater treatment facilities.

\subsection{Southern California Wastewater Treatment Facility}

A wastewater treatment facility located in San Diego County, California, processes over 38 million liters (10 million gallons) daily. The facility operates at an average demand of $2 \mathrm{MW}$, with peak demand reaching 2.5 MW. While this facility has yet to implement any demand response measures, data obtained during normal facility operation reveal significant potential for demand response. Figure 10 shows facility-wide demand reductions which occurred when two effluent pumps were shut down during normal facility operation.

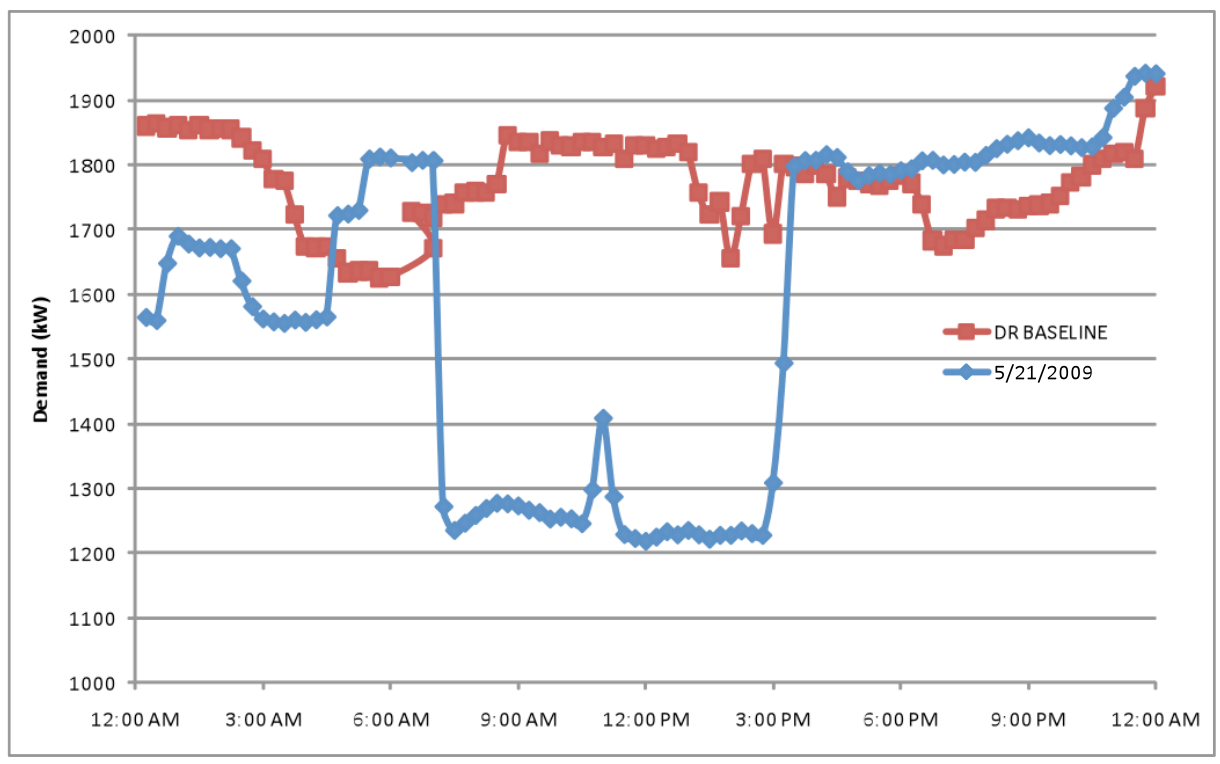

Figure 10. Load Reduction at Site During Normal Facility Operation

The facility was able to reduce average demand by $540 \mathrm{~kW}$, or $30 \%$ of total facility load, during the shut down of the two effluent pumps. Further, shut down of a centrifuge on another day reduced facility load by an additional $55 \mathrm{~kW}$.

The potential for OpenADR is enhanced by a SCADA system which has the ability to control all facility equipment. Further, this wastewater treatment facility is in the process of installing engines/generators capable of producing about $750 \mathrm{~kW}$ of on-site generated energy, run off of either natural gas or digester gas. This additional demand could be exhausted during a demand response event. 


\subsection{Town of Discovery Bay Community Services District}

The Town of Discovery Bay operates a wastewater treatment facility in Northern California which, on average, processes 6 million liters (1.6 million gallons) per day (Quantum Consulting.). A total capacity of 43.5 million liters (11.5 million gallons) is stored in two lagoons that operate four $11 \mathrm{~kW}(15 \mathrm{HP})$ aerators 24 hours per day, seven days per week. Further, the wastewater treatment facility operates two oxidation ditches, each with a storage capacity of 4 million liters (1 million gallons). Each oxidation ditch is served by four $22 \mathrm{~kW}(30 \mathrm{HP})$ aerators which are manually controlled and typically operating all the time.

In 2003, the facility replaced the four $11 \mathrm{~kW}(15 \mathrm{HP})$ aerators in the lagoons with two solar-powered mixers, one in each lagoon (Sullivan 2006). The solar powered mixers are equipped with batteries which allow 24 hour operation, and also have the ability to operate for up to 7 days without significant sunlight. Further, DO levels in the two oxidation ditches were found to typically be between 3.0 and $5.0 \mathrm{mg} / \mathrm{L}$, well above the minimum desired level of $1.5 \mathrm{mg} / \mathrm{L}$. By installing automated DO sensors and integrating them with an existing SCADA system, the facility was able to operate only two aerators in each ditch, with additional aerators cycling on and off as necessary to allow proper mixing in the ditches and to maintain a constant DO level of 1.5 to 2.0 $\mathrm{mg} / \mathrm{L}$.

Retrofitting the lagoons by replacing the four $11 \mathrm{~kW}(15 \mathrm{HP})$ aerators with two solar powered mixers reduced the facility demand by $31 \mathrm{~kW}$ and saved 276,698 $\mathrm{kWh} / \mathrm{yr}$, producing $\$ 48,947$ in cost savings. Upgrading the oxidation ditches by installing automated DO sensors allowed the facility to save energy from unnecessary aeration. This allowed the facility to reduce the electricity demand by $48 \mathrm{~kW}$ and to save 427,488 $\mathrm{kWh} / \mathrm{yr}$, producing $\$ 31,862$ in cost savings. The total facility upgrade cost $\$ 125,337$, which was partially offset by a rebate of $\$ 77,466$ from a California utility incentive program. The improvements saved the facility $\$ 80,629$ annually in energy costs, resulting in a simple payback of seven months (Quantum Energy Services \& Technologies Inc.).

\subsection{Encina Wastewater Authority}

The Encina Wastewater Authority has a treatment capacity of 164 million liters (43.3 million gallons) per day and processes on average 98 million liters per day (26 million gallons per day)(Jardin 2009), and serves 324 square kilometers (125 square miles) in Southern California (California Energy Commission 2003). When expanding their facility, Encina implemented several energy efficiency strategies in addition to load management measures.

Encina upgraded coarse-bubble diffusers with more-efficient fine-bubble versions. The facility uses probes throughout aeration basins to monitor and maintain dissolved oxygen levels automatically. Load management efforts included rescheduling pumping and treatment processes to off-peak hours and manually shutting down energy intensive equipment during peak hours. The implementation of these strategies saves 
the Encina Wastewater Authority over $\$ 600,000$ each year, with the load management efforts alone saving $\$ 50,000$ annually.

\subsection{Moulton Niguel Water District}

The Moulton Niguel Water District processes 64 million liters (17 million gallons) of wastewater each day, and serves 97.1 square kilometers (37.5 square miles) in Southern California with 77 district pumping stations (California Energy Commission 2003).

Faced with rising electricity rates, the District underwent several energy efficiency and load management retrofits to reduce facility operating costs. The District uses PLCs to activate pumps during off-peak periods and to halt pumping during times of peak electricity demand. The District also upgraded motors with energy efficient motors equipped with VFDs linked to PIDs. This system is used to regulate wastewater levels by adjusting wastewater flow. Instead of cycling pumps on and off to distribute wastewater, the system now provides a constant flow, using less energy, reducing motor wear and tear, and reducing high energy demand from motor starting surges.

Using PLCs to pump only during off-peak hours saves the facility nearly $\$ 320,000$ annually, and the District's electric bill fell by $20 \%$. Using PIDs and VFDs to control pump motors has reduced facility pumping costs by $4 \%$. The implementation of these strategies saves the Moulton Niguel Water District \$332,000 annually.

\subsection{Dublin San Ramon Services District}

The Dublin San Ramon Services District (DSRSD) operates a wastewater treatment facility serving over 120,000 residents in Northern California. The facility implemented several energy efficiency measures when adding additional aeration tanks and increasing aeration blower capacity (Pacific Gas and Electric Company 2006).

When retrofitting the facility, DSRSD installed National Electric Manufacturers Association premium-efficiency motors with VFDs on pumps and single-stage aeration fans, which operate $31 \%$ more efficiently than a multi-stage unit. They also redesigned the treatment system to reduce head loss by raising the water level in secondary sedimentation tank and moving the recycled water facility closer to the process. Additionally, DSRSD installed UV lamps to disinfect recycled water $64 \%$ more efficiently.

Through the redesign of the wastewater treatment facility, the DSRSD is able to treat $48 \%$ more wastewater. Although the energy efficiency retrofits cost an additional $\$ 2,209,000$, the annual energy savings and incentives ensures a payback in 6.6 years.

\subsection{East Bay Municipal Utility District}

The East Bay Municipal Utility District (EBMUD) treats 1.57 billion liters (415 million gallons) of wastewater a day and serves over 600,000 residential and 20,000 commercial customers in Northern California (California Energy Commission 2003).

Since 1985, EBMUD has implemented several energy efficiency measures in the Special District 1 Wastewater Treatment Plant. EBMUD uses waste methane produced by the 
facility's digesters to cogenerate $40-50 \%$ of the facility's electricity, providing 7.1 megawatts. They replaced two smaller compressors with one large unit and installed high-efficiency motors with VFDs on pumps, reducing electricity use by pumps by $50 \%$. They discontinued the use of one digester reactor and increased off-peak pumping in other reactors to compensate, as well as discontinuing all second-stage activated sludge mixing processes after discovering that the process had little impact on wastewater. EBMUD also added plastic balls to prevent heat losses in the oxygen production vaporizer pit. Lastly, they inter-tied pipes on gas recirculation blowers to allow one blower to serve two mixing tanks.

EMBUD implemented these measures through the use of a control system, which regulated influent pump flow, controlled water storage, and rescheduled pumping to off-peak hours. These energy efficiency measures reduced facility energy use by $60 \%$, and saved the facility $\$ 2,796,000$ each year in reduced energy costs. 


\subsection{Conclusion}

This study has shown the wastewater treatment facilities can be excellent candidates for demand response. Facilities which have implemented energy efficiency measures and have centralized control systems may be able to shift or shed process loads in response to financial incentives, utility bill savings, and/or opportunities to enhance reliability of service. Control technologies installed for energy efficiency and load management purposes can often be adapted for OpenADR at little additional cost. These improved controls may prepare facilities to be more receptive to OpenADR due to both increased confidence in the opportunities for controlling energy cost/ use and access to the realtime data. Municipal wastewater treatment facilities and four industrial sectors: food processing, petroleum, electronics, and cement were examined, and major opportunities for demand reduction were found to be most applicable to municipalities and food processing facilities, due to the magnitude of the energy use, number of facilities, and the little indication of significant energy and water saving technologies being introduced in these sectors.

Characteristics of the wastewater stream such as the presence of total dissolved solids, nitrogen, phosphorus, heavy metals, and organics determine wastewater stream quality and are used to establish wastewater effluent regulations. Municipal and industrial wastewater treatment facilities treat wastewater to ensure the discharge is in compliance with federal and local regulations. Variations in pollutant levels and composition will require different treatment methods and energy use.

Wastewater treatment facility energy demand varies widely depending on factors such as facility size, location, and seasonal and daily load variations. The main energy enduses in wastewater treatment facilities are processes such as pumping, aeration, and solids handling. Peak loads occur in the late morning and late evening in municipal wastewater treatment facilities, and loads remain high during the utility peak periods, while in food processing facilities, loads are highly variable depending on a number of factors, including seasonal variations and the types of products being processed.

Equipment energy use in the wastewater treatment process shows potential areas for energy efficiency and implementation of demand response strategies. The most energyintensive equipment in a wastewater treatment facility are pumps and aerators fans. The energy required for influent wastewater pumping can range from 15-70\% of the total facility electrical energy use. Further, a typical diffused aeration system can devote 50$90 \%$ of its electric power to run aerator blower motors. Developing demand response strategies focusing on this key equipment will result in the greatest magnitude load reduction.

Key equipment in the wastewater treatment process is controlled by RTU/PLCs, which often communicate with a centralized control system. Integrated centralized control systems are becoming more commonplace in wastewater treatment facilities. These systems allow for greater control of facility processes, and can also be used in the integration of OpenADR strategies. 
This study identified several energy efficiency and OpenADR opportunities in wastewater treatment facilities. Energy efficiency opportunities include: installing VFDs on aerator blower motors and pumps, replacing coarse-bubble diffusers with finebubble diffusers, maintaining flow equalization, lighting and HVAC retrofits, improving storm water management, and utilizing facility-based energy sources. Demand response strategies include: turning off or reducing the load of aerators blowers and pumps by utilizing VFDs, using on-site power generators, reducing lighting and HVAC loads, and over-oxygenating wastewater prior to a demand response event, using storage capacity to hold untreated wastewater during peak demand periods, and rescheduling backwash pumps operation.

The research and conclusions reached in this report offer insights to help shape the path of further demand response research in wastewater treatment facilities. This research might include: the development of more advanced DR-enabling control technologies or collecting data from facilities which participate in demand response activities and analyzing the data to determine the most successful OpenADR strategies. Collecting data and performing analyses to address the issue of stock turnover rate for equipment such as pumps and blowers could help further target opportunities for introducing energy efficiency and demand response-enabled equipment. Field study of facilities could help determine which loads to shed, how to use existing technologies to plan demand response events and energy efficiency, which technologies need to be upgraded to enable activities, and how to interact with utilities to ensure benefits and support for participation. 


\subsection{References}

ANON Incorporated (1999). $\mathrm{SO}_{3}$ Gas-Phase Cleaning Process.

Applied Integration UK Ltd. (2008). "DCS." Retrieved September 5, 2008, from http://www.appliedintegration.co.uk/services/solutions/dcs/.

Aqua Sierra Inc. (2000). "City of Ouray, Wastewater Treatment Plant: Surface Aerators vs. Air Diffusion Systems Bottom Laid Diffuser Aeration." Water Online.

ARC Advisory Group (2007). "SCADA Market for Water \& Wastewater to Exceed \$275 M." WaterWorld.

Australian Government (2008). Emission Estimation Technique Manual for Cement Manufacturing Department of the Environment Water Heritage and the Art, Commonwealth of Australia.

Baier-Anderson, C. (2008). "Nano Down the Drain." Environmental Defense Fund.

Barnes, D., Forster, C.F. and Hrudey, S.E., (1984). Surveys in Industrial Wastewater Treatment Food and Allied Industries. London, England., Pitman Publishing Limited.

BASE Energy Inc. (2006). Energy Baseline Study for Municipal Wastewater Treatment Plants.

Bentley Systems Inc. (2004). The Fundamentals of SCADA.

Benyahia, F., M. Abdulkarim, A. Embaby, and M. Rao (2006). Refinery Wastewater Treatment: A True Technological Challenge. The Seventh Annual U.A.E. University Research Conference. U.A.E. University.

Bolles, S. Modeling Wastewater Aeration Systems to Discover Energy Savings Opportunities, Process Energy Services LLC.

Bough W. and R. Carawan (1996). "Wastewater Pretreatment in Dairy Plants: Does it Save Money?" Water Quality and Waste Management.

Brown R. and J. Koomey (2003). "Electricity Use in California: Past Trends and Present Usage Patterns." Energy Policy 31: 849-864.

Byron, M. (2005). Achieving Zero Liquid Discharge in the Semiconductor Industry, Columbia University.

California Department of Water Quality. (2008). "Stormwater Regulatory Data." Retrieved November 30, 2008, from http:/ / www.stormwaterauthority.org/regulatory data/state.aspx?id=124.

California Energy Commission. (2000). "Fuel Cells." Retrieved April 17, 2009, from http:/ / www.energy.ca.gov/process/pubs/fuelcell.pdf.

California Energy Commission (2003). Water/Wastewater Process Energy, Case Studies: East Bay Municipal Utility District, Special District 1, Wastewater Treatment.

California Energy Commission (2003). Water/Wastewater Process Energy, Case Studies: Encina Wastewater Authority.

California Energy Commission (2003). Water/Wastewater Process Energy, Case Studies: Moulton Niguel Water District.

California Energy Commission (2005). California's Water-Energy Relationship.

California Energy Commission. (2008). "Anaerobic Digestion." Retrieved August 21, 2008, from WWW.ENERGY.CA.GOV / PIER / RENEWABLE / BIOMASS / ANAEROBIC DIGESTION /.

California Energy Commission (2008). California's Food Processing Industry Energy Efficiency Initiative, California State Commission.

California Energy Commission. (2008). "California Petroleum Industry." from http:/ / www.energy.ca.gov/research/iaw/industry/petro.html.

California Energy Commission (2008). California Sector Profile \& Energy Use.

California Energy Commission. (2008). "Computer and Electronics Industry Profile." Retrieved 2/10/2009, from http://www.energy.ca.gov/research/iaw/industry/comp.html. 
California Energy Commission. (2008). "Semiconductors." from http:/ / www.energy.ca.gov/research/iaw/industry/semi.html.

California Green Solutions (2007). "Food Manufacturing Industry Overview." California Green Solutions.

California Institute of Food and Agricultural Research (2006). Technology Roadmap Energy Efficiency in California's Food Industry.

California Office of the Governor. (2001). "Governor Davis Announces \$1.7 Million For Moulton Niguel Water District Projects ".

Canadian Terrestrial Ecosystem Model (2000). Industrial Pollution Prevention and Abatement for Cement Manufacturing Industry

Carbone, J. (2008). "RoHS has cost the electronics industry more than $\$ 32 . "$ from http: / / www.purchasing.com/article/CA6552730.html.

Carns, K. (1998). Quality Energy Efficiency Retrofits for Wastewater Systems, EPRI.

Carns, K. (2004). Bringing Energy Efficiency to the Water and Wastewater Industry: How Do We Get There? Water \& Wastewater Energy Roadmap Workshop, Washington, DC.

Cho, C. H. (1984). Computer-Based Energy Management Systems. Orlando Academic Press, Inc.

Chu, C. P., D.J Lee, and C.Y. Chang (2005). "Energy Demand in Sludge Dewatering." Water Research 39(9): 1858-1868.

City of San Diego. "Point Loma Wastewater Treatment Plant." from http:/ / www.sandiego.gov/mwwd/facilities/ptloma.shtml.

Coito, F., F. Powell, E. Worrell, L. Price, and R. Friedmann (2000). Case Study of the California Cement Industry, Lawrence Berkeley National Laboratory.

Communication Technologies Inc. (2004). "Supervisory Control and Data Acquisition (SCADA) Systems." NCS Technical Information Bulletin 04-1.

Consortium for Energy Efficiency (2006). National Municipal Water and Wastewater Facility Initiative.

COWI Consulting Engineers and Planners (2000). Cleaner Production Assessment in Meat Processing, United National Environment Programme, Division of Technology, Industry and Economics.

Delhi College of Engineering (2007). "IOTA." Annual Technical Journal 13.

Department of Energy (2003). Hydropower Setting a Course for Our Energy Future.

Department of Energy (2006). Improving Pumping System Performance: A Sourcebook for Industry.

Department of Environmental Protection Bureau of Land \& Water Quality (2002). "Energy Conservation in Wastewater Treatment Facilities." Operation \& Maintenance Newsletter.

Dugger, P. (2008). Emerging Green Trends for Wineries- Energy Management

East Bay Municipal Utility District. "Wastewater Treatment Process Online Tour." Retrieved August 4, 2008, from http://www.ebmud.com/wastewater/online tour/.

Efficiency Vermont. "Reduce Energy Use at Water and Wastewater Facilities." from http:/ / www.efficiencyvermont.com/stella/filelib/WaterWastewaterTechBrief.p df.

Egyptian Environmental Affairs Agency (2005). Environmental Impact Assessment Guidelines for Cement Manufacturing Plants.

Electric Power Research Institute (1994). Energy Audit Manual for Water/Wastewater Facilities.

Electric Power Research Institute (1999). Technical Brief: A Need for Disinfection Alternatives.

Energetics Incorporated (2004). Energy Efficiency Roadmap for Petroleum Refineries in California 
Energy Conservation Task Force of the Water Environment Federation (1997). Energy Conservation in Wastewater Treatment Facilities. WEF Manual of Practice No. FD-2.

Energy Information Administration (2002). Energy Consumption by Manufacturers.

Energy Information Administration (2002). Table 1.1 First Use of Energy for All Purposes (Fuel and Nonfuel)

Energy Information Administration. (2009). "Number of U.S. Operable Petroleum Refineries ", from http:/ / www.eia.doe.gov/basics/quickoil.html.

Environmental Agency (2005). Measuring Environmental Performance: Sector Report For the Cement Industry, Environmental Agency.

Environmental Protection Agency (1995). "Case Studies in Residual Use and Energy Conservation at Wastewater Treatment Plants." Interagency Energy and Environmental Research Report.

Environmental Protection Agency (1999). Wastewater Technology Fact Sheet: Fine Bubble Aeration.

Environmental Protection Agency (2002). Federal Water Pollution Control Act: 108.

Environmental Protection Agency (2004). Clean Watersheds Needs Survey.

Environmental Protection Agency (2004). Technical Development Document for the Final Effluent Limitations Guidelines and Standards for the Meat and Poultry Products Point Source Category (40 CFR 432).

Environmental Protection Agency (2006). 40 CFR Part 419 Petroleum Refining Point Source Category.

Environmental Protection Agency (2006). Wastewater Management Fact Sheet Energy Conservation Office of Water.

Environmental Protection Agency. (2008). "Cement Kiln Dust Waste." Retrieved July 8, 2008, from http:/ / www.epa.gov/epaoswer/other/ckd/index.htm.

Environmental Protection Agency. (2008). "Effluent Limitation Guidelines Frequent Questions." from http:/ / www.epa.gov/ waterscience/guide/questions / \#bpt.

Environmental Protection Agency (2008). Ensuring a Sustainable Future: An Energy Management Guidebook. Office of Wastewater Management.

Environmental Protection Agency. (2008). "Fuel Cells \& Vehicles." from http:/ / www.epa.gov/fuelcell/basicinfo.htm.

Environmental Protection Agency. (2008). "Stormwater Basic Information." from http:/ / cfpub1.epa.gov/npdes/stormwater/swbasicinfo.cfm.

Environmental Protection Agency. (2009). "Water Discharge Permits." Retrieved April 21, 2009.

ExperTune Inc. (2008). "What Is PID Tutorial Overview." ExperTune.

Findhorn Ecovillage. (2008). "The Living Machine." Retrieved January 13, 2009, from http:/ / www.ecovillagefindhorn.com/biological/tech.php.

Flex your Power. (2008). "Demand Response Programs." Retrieved 10/10/2008, from http:/ / www.fypower.org/flexalert/demand resp faq.html.

Frost and Sullivan (2006). Impact of Nanotechnology in Water and Wastewater Treatment.

Fuller, J. (2003). Energy Efficient Alternative for the Fortuna Wastewater Treatment Facility, The Community Clean Water Institute.

Garbrecht, S. (2008). "How Wonderware Software Addresses the Top Challenges of the Municipal Water and Wastewater Business." Invensys Systems, Inc.

GEA Process Engineering Inc. "CIP Cleaning-In-Place/ SIP Sterilization-In-Place." from http:/ / www.niroinc.com/gea liquid processing/cleaning in place sip.asp.

Global Energy Partners LLC (2007). Enhancing Digester Operation.

Green, F. B., T.J. Lundquist, and W.J. Oswald (1995). "Energetics of Advanced Integrated Wastewater Pond Systems." Water Science Technology 31(12): 9-20.

Hayden, B. (2007). Virginia Beach Infuses Cleanup Plant with Innovation. 
Hemert, G. V., and I. Spronk (2006). "VFDs Can Help Reduce Aeration Basin Energy Costs." WaterWorld.

Hinter, G. (2005). "Solar Energy For Wastewater Treatment." University of South Australia.

Hosokawa, M. (2007). Nanoparticle Technology Handbook, Elsevier.

International Finance Corporation (2007). Environmental, Health, and Safety Guidelines for Semiconductors \& Other Electronics Manufacturing.

ITT Corporation (2007). ITT's Place in the Cycle of Water.

Jardin, J. (2009). Encina Wastewater Authority.

Jenkins, T. (1996). "Retrofitting VFD Motors at a Waste Water Treatment Plant." from http://ecmweb.com/mag/electric retrofitting vfd motors/.

Jolley, A. (2006). Technologies for Reducing Stationary Energy Use. Climate Change Project Working Paper Series, Victoria University of Technology

Kadam, A., G. Oza, P. Nemade, S. Dutta, and H. Shankar (2007). "Municipal Wastewater Treatment Using Novel Constructed Soil Filter System." Chemosphere 71(5): 975981.

Kelo Technology. "The Green System for Waste Water Treatment." from http:/ / www.ecosmarte.com.au/waste water/kelo science.pdf.

Kiliccote, S., and M.A. Piette, (2008). Automation of Capacity Bidding with an Aggregator Using Open Automated Demand Response, Lawrence Berkeley National Laboratory.

Kleyman, J. (2006). Municipal Wastewater Treatment Plant Energy Evaluation. Buffalo, NYSERDA.

Kogge, P. M. (2008). Central Processing Unit. Microsoft Encarta Online Encyclopedia

Lewis, G., I. Rhyne, B. Atkinson, (2009). California Food Processing Industry Wastewater Demonstration Project: Phase I Final Report., PIER Industrial/Agricultural/Water End-Use Energy Efficiency Program.

Lyco Manufacturing (2007). "Streamlining Wastewater Treatment In Poultry Processing." Water Online.

Maine Lagoon Systems (2003). Fundamentals of Lagoon Aeration Department of Environmental Protection State of Maine.

Mannapperuma, J., E. Yates and R. Singh (1993). Survey of Water Use in the California Food Processing Industry. Food Industry Environmental Conference.

Massachusetts Water Resources Authority (2007). Deer Island Treatment Plant Performance.

McInerney, F., and S. White (1995). The Total Quality Corporation.

Means, E. (2004). Water and Wastewater Industry Energy Efficiency: A Research Roadmap, Awwa Research Foundation.

Meeroff, D., and F. Bloetscher (1999). "Sludge Management, Processing, Treatment, and Disposal." Florida Water Resources Journal.

Menn, J. (2001). Firms' Use of Backup Diesel Generators Attracting Heat. Los Angeles Times.

Merritt, R. (2008). "Control System Architectures: Remote Control." ControlGlobal.

Metcalf \& Eddy Inc. (2003). Wastewater Engineering, Treatment and Reuse, McGrawHill.

Mohamed Al Zarooni and Walid Elshorbagy (2006). "Characterization and Assessment of Al Ruwais Refinery Wastewater." Journal of Hazardous Materials 136(3): 398405.

Nanowerk Research (2007). "New Nanotechnology Wastewater Treatment System For Removing Heavy Metals." Journal of Separation Science and Journal of Colloid Interface Science. 
National Estuarine Research Reserve System. (2004). "System-wide Monitoring Program Dissolved Oxygen." Retrieved February 25, 2008, from http://www.nerrs.noaa.gov/Monitoring/WaterOxygen.html.

National Small Flows Clearinghouse (1997). "Wastewater." Pipeline 8(4).

Natural Resources Defense Council (2004). Energy Down the Drain: The Hidden Costs of California Energy, Pacific Institute.

Neenan, R. (2008). Comments Regarding Draft California Energy Efficiency Strategic Plan

Noding, K. (2007). "Industry Overview Construction Materials " Storebrand Investments SRI.

North Dakota Department of Health. (2005). "Total Suspended Solids." Retrieved July 11,2008 , from http://www.health.state.nd.us/wq/sw/Z6 WQ Standards/WQ TSS.htm.

Nosier, S. A. (2003). "The Effects of Petroleum Refinery Wastewater on the Rate of Corrosion of Steel Equipment." Anti-Corrosion Methods and Materials 50(3): 217222.

NYSERDA (2006). Municipal Wastewater Treatment Plant Energy Evaluation.

NYSERDA (2006). NYSERDA Submetering Program Summary Report.

Offik, M., F. Stauble, and R. Turley (2006). "Pump Energy Savings with VFDs." PlantServices.com.

Ontario Centre for Municipal Best Practices (2006). General Energy Management Practices.

Pacific Gas and Electric Company (2006). Wastewater Treatment Plant Achieves Energy and Resource Savings with Efficient Design.

Pacific Gas and Electric Company. (2008). "What is Demand Response?" Retrieved $10 / 10 / 2008$, from http://www.pge.com/mybusiness/energysavingsrebates/demandresponse/w hatisdemandresponse/.

Pacific Northwest Pollution Prevention Resource Center (2000). Energy and Water Efficiency for Semiconductor Manufacturing.

Pacific Northwest Pollution Prevention Resource Center. (2008). "Semiconductor Manufacturing: Operations." Retrieved March 23, 2009.

Pakenas, L. J. (1995). Energy Efficiency in Municipal Wastewater Treatment Plants, NYSERDA.

Partington, G. (1998). "Stand-Alone: Basic, Low-Cost, Programmable Access Control." Security Solutions.

Phillips, R. J. (1997). Wastewater Reduction and Recycling in Food Processing Operations, Food Manufacturing Coalition for Innovation and Technology Transfer.

Piette, M. A., G.Ghatikar, S. Kiliccote, E. Koch, D. Hennage, P. Palensky, and C. McParland, (2009). Open Automated Demand Response Communications Specification (Version 1.0), California Energy Commission, PIER Program.

Piette, M. A., S. Kiliccote, and G. Ghatikar (2007). Design and Implementation of an Open, Interoperable Automated Demand Response Infrastructure, Lawrence Berkeley National Laboratory.

Portland Cement Association. (2003). "Overview of the Cement Industry." Retrieved July 3, 2008, from http:/ / www.cement.org/basics/ cementindustry.asp.

Quantum Consulting. (2004). California Wastewater Process Optimization Program: Detailed Process Audit Summary and Recommendations.

Quantum Energy Services \& Technologies Inc. "Discovery Bay CSD Wastewater Facility: Increased Energy Efficiency, Increased Reliability, and Reduced Costs." from http:// www.calwastewater.com/pdf/DiscoveryBayCaseStudy.pdf. 
S.A. Jenabali Jahromi and A. Janghorban (2004). "Assessment of Corrosion in Low Carbon Steel Tubes of Shiraz Refinery Air Coolers " Engineering Failure Analysis 12(4): 569-577.

Sanchez, A., M. Wade, and M.R. Katebi (2005). "A Software Platform for Real-Time Control and Monitoring of a Wastewater Treatment Plant." Transactions of the Institute of Measurement and Control 27(3): 153-172.

SCADA World (2007). SCADA: An Introduction.

SCADA World (2007). SCADA: Human Machine Interface (HMI).

SCADA World. (2007). "SCADA: Master Station." from http://www.scadaworld.net/master-station.html.

Schultz, T. (2008). "Water Management in the Petroleum Industry." Pollution Engineering.

Siemens Water Technologies (2005). "Siemens Develops New Modular Ammonia Treatment System for Semiconductor Wastewater." AZoM Materials.

Siemens Water Technologies (2006). "Improving Feed Water Recovery and Reducing Backwash Waste In Membrane Filtration Process." Water Practice \& Technology 1(4).

Siemens Water Technologies (2007). "New Solutions for Disinfecting Drinking Water and Wastewater Improve Water Quality and Reduce Risks to Health." Siemens Water Technologies Corp.

Sullivan, E. (2006). Solar-powered Circulators Provide Sure-Fire Barrier to Noxious Odors. U.S. Water News: 13.

Tchobanoglous, G., L.B. Franklin, Metcalf, Eddy, D. Stensel (2002). Wastewater Engineering: Treatment and Reuse McGraw-Hill Professional

The California Energy Commission. (2008). "Renewable Energy Research: Biomass Anaerobic Digestion." Retrieved December 12, 2008, from http:/ / www.energy.ca.gov/research/renewable/biomass/anaerobic digestion index.html.

The Hendrix Group Inc. (2005). "Petroleum Refining Corrosion." Retrieved July 8, 2008, from http:// www.hghouston.com/ refining.html.

U.S. Census Bureau (2002). Cement Manufacturing: 2002. U.S. Department of Commerce.

U.S. Census Bureau (2002). NAICS Definitions 334 Computer and Electronic Product Manufacturing.

U.S. Census Bureau. (2002). "Petroleum and Coal Products Manufacturing." from http: / / factfinder.census.gov/ servlet/IBQTable? bm=y\&ds name $=$ EC0231SG105\&-NAICS2002 $=324$.

U.S. Department of Energy Energy Efficiency and Renewable Energy (2007). Pumping Tip Sheets. Washington, DC.

USAEP. (2008). "Clean Technologies in U.S. Industries: Focus on Food Processing." Retrieved June 31, 2008, from http:/ / www.p2pays.org/ ref/09/08853.htm.

Wang, L. (2005). Waste Treatment in the Process Industries, CRC Press.

Waste Reduction Resource Center. (2008). "Environmental Impacts from Meat and Fish Processing." Retrieved July 7, 2008, from http:/ / wrrc.p2pays.org/p2rx/ subsection.cfm?hub $=449 \&$ subsec $=15 \&$ nav $=15 \& C$ FID $=1711299 \&$ CFTOKEN=82506417.

Water Environment Federation (2007). Operation of Municipal Wastewater Treatment Plants: Manual of Practice No. 11, Volume II.

Water Systems Council. (2007). "Total Dissolved Solids." Retrieved July 15, 2008, from http:/ / www.watersystemscouncil.org/VAiWebDocs/WSCDocs/2010920TDS_F INAL.pdf.

Wells, J. (2004). Solutions for Energy Security \& Facility Management Challenges: Proceedings Marcel Dekker. 
Wildman, M. (2005). "A Green Alternative for Wastewater Treatment." cenews.com. Wilkinson, R. (2000). Methodology for Analysis of the Energy Intensity of California's Water Systems and An Assessment of Multiple Potential Benefits Through Integrated Water-Energy Efficiency Measures, University of California Santa Barbara.

William Nazaroff and Lisa Alvarez-Cohen (2004). Environmental Engineering Science. New York, John Wiley \& Sons, Inc.

Wilson, A. (1993). "Cement and Concrete: Environmental Considerations." Environmental Building News.

Yang, G. (2002). "CMP Wastewater Management Using the Concepts of Design for Environment." Environmental Progress.

Yonkin, M. C. (2007). Energy Smart Focus Program for NY's Water and Wastewater Sectors, Malcolm Pirnie and NYSERDA.

Zabrocki J. and P. Larson (2008). "Blown Out of the Wastewater." Water and Wastes Digest. 



\subsection{Glossary}

\begin{tabular}{|c|c|}
\hline ADR & Automated Demand Response \\
\hline AIWPS & Advanced Integrated Wastewater Pond System \\
\hline $\mathrm{BOD}_{5}$ & Biological Oxygen Demand \\
\hline CEC & California Energy Commission \\
\hline CFR & Code of Federal Regulations \\
\hline CFU & Colony Forming Units \\
\hline COD & Chemical Oxygen Demand \\
\hline DCS & Distributed Control Systems \\
\hline DO & Dissolved Oxygen \\
\hline DR & Demand Response \\
\hline DRRC & Demand Response Research Center \\
\hline DSRSD & Dublin San Ramon Services District \\
\hline EBMUD & East Bay Municipal Utility District \\
\hline EPA & Environmental Protection Agency \\
\hline GWh & Gigawatt Hour \\
\hline HMI & Human Machine Interface \\
\hline HP & Horsepower \\
\hline HVAC & Heating, Ventilating, and Air-Conditioning \\
\hline $\mathbf{I} / \mathbf{O}$ & Input/ Output \\
\hline kW & Kilowatt \\
\hline kWh & Kilowatt Hour \\
\hline $\mathbf{L}$ & Liter \\
\hline LBNL & Lawrence Berkeley National Laboratory \\
\hline MG & Million Gallons \\
\hline mg & milligrams \\
\hline MGD & Million Gallons Per Day \\
\hline ML & Megaliter \\
\hline $\mathrm{mL}$ & Milliliter \\
\hline MTU & Master Terminal Units \\
\hline MW & Megawatt \\
\hline NPDES & National Pollutant Discharge Elimination System \\
\hline NTU & Nephelometric Turbidity Units \\
\hline NYSERDA & New York State Energy Research and Development Authority \\
\hline OpenADR & Open Automated Demand Response \\
\hline
\end{tabular}




$\begin{array}{ll}\text { PG\&E } & \text { Pacific Gas and Electric } \\ \text { PID } & \text { Proportional Integral Derivatives } \\ \text { PIER } & \text { Public Interest Energy Research } \\ \text { PLC } & \text { Programmable Logic Controllers } \\ \text { RTU } & \text { Remote Terminal Units } \\ \text { SCADA } & \text { Supervisory Control and Data Acquisition } \\ \mathrm{SO}_{3} & \text { Sulfur Trioxide Gas } \\ \text { TSS } & \text { Total Suspended Solids } \\ \text { U.S. } & \text { United States } \\ \text { UV } & \text { Ultraviolet } \\ \text { VFD } & \text { Variable Frequency Drive }\end{array}$

